\title{
Ranking of Texas Reservoirs
}

\author{
for Application of Carbon
}

\section{Dioxide Miscible Displacement}

April 1996

Jerry Ham

Science Applications International Corporation 8301 Greensboro Drive 


\section{DISCLAIMER}

Portions of this document may be illegible in electronic image products. Images are produced from the best available original document. 


\section{Disclaimer}

This report was prepared as an account of work sponsored by an agency of the United States Government. Neither the United States Government nor any agency thereof, nor any of their employees, makes any warranty, express or implied, or assumes any legal liability or responsibility for the accuracy, completeness, or usefulness of any information, apparatus, product, process disclosed, or represents that its use would not infringe privately owned rights. Reference herein to any specific commercial product, process, or service by trade name, trademark, manufacturer, or otherwise, does not necessarily constitute or imply its endorsement, recommendation, or favoring by the United States Government or any agency thereof. The views and opinions of authors expressed herein do not necessarily state or reflect those of the United States Government or any agency thereof. 


\section{Contents}

Page

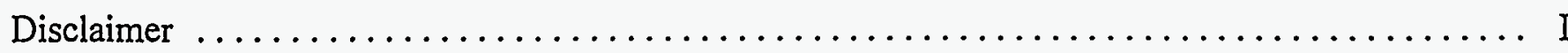

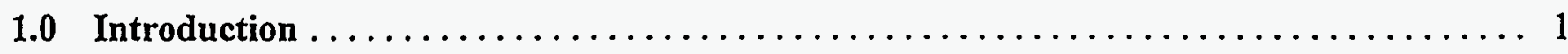

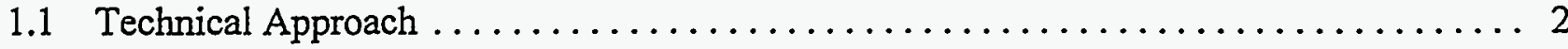

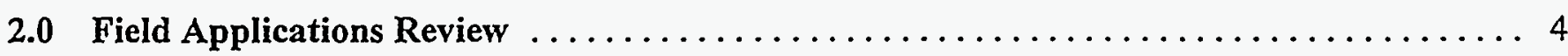

2.1 Miscible Field and Pilot Projects ................................ 4

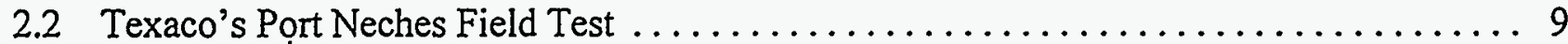

2.2.1 Relevance of the Technical Demonstration ..................... 9

2.2.2 Encouraging Private Sector Implementation $\ldots \ldots \ldots \ldots \ldots \ldots \ldots \ldots$

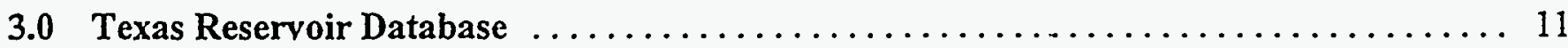

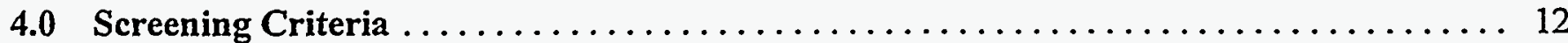

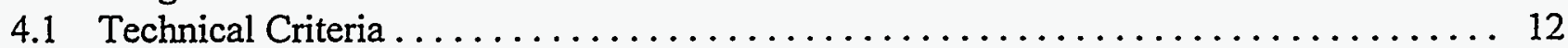

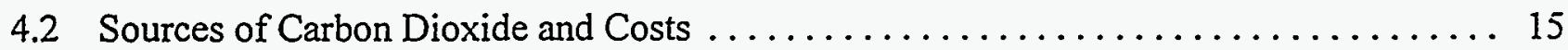

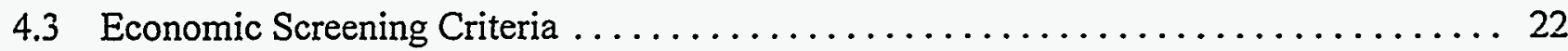

4.4 Assumptions and Limitations Used in the Screening $\ldots \ldots \ldots \ldots \ldots \ldots \ldots \ldots \ldots \ldots \ldots$

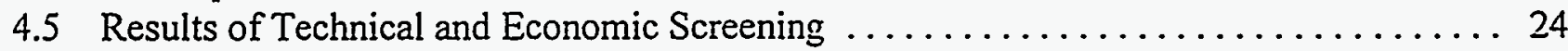

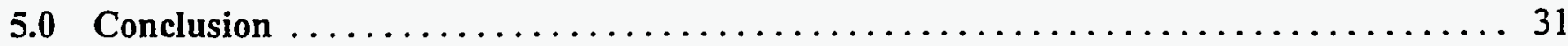

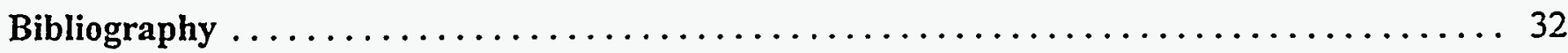

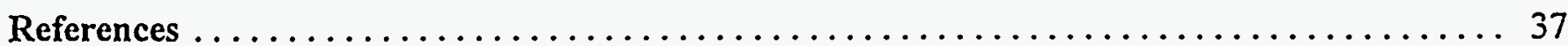

Appendices

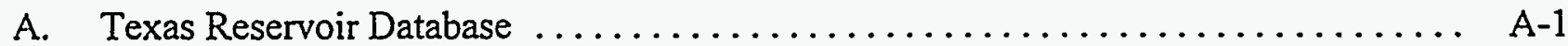

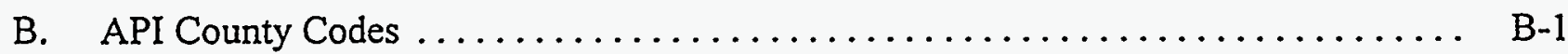

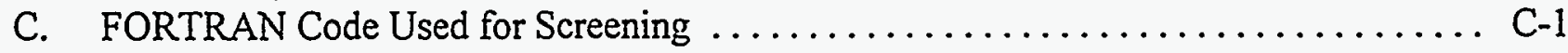




\section{Tables}

2.1.1 Summary of Field and Pilot Applications of the Carbon Dioxide Miscible

Displacement in Waterflooded Sandstone Reservoirs ..................... 5

4.1.1 Optimum Reservoir Parameters, Upper Limit, and Weighting Factors . . . . . . . . . 13

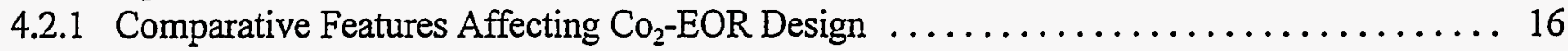

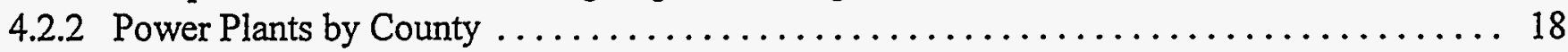

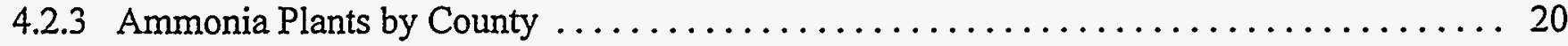

4.2.4 List of Fluid Catalytic Cracking Units $\mathrm{CO}_{2}$ Generation Capacity $\ldots \ldots \ldots \ldots \ldots \ldots \ldots \ldots \ldots \ldots \ldots \ldots$

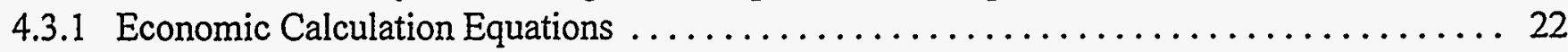

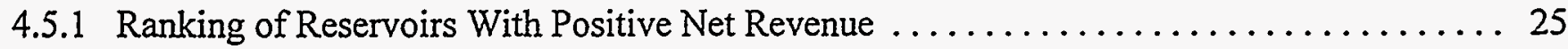




\section{Figures}

4.1.1 Average Oil Production as a Percent of Oil Saturation $\ldots \ldots \ldots \ldots \ldots \ldots \ldots \ldots \ldots \ldots \ldots$

4.1.2 Average Oil Production as a Function of Pressure Ratio . . . . . . . . . . . . . . . . 14

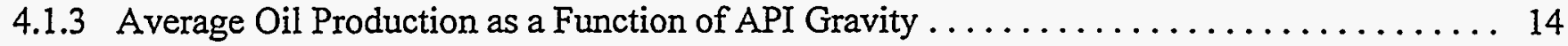

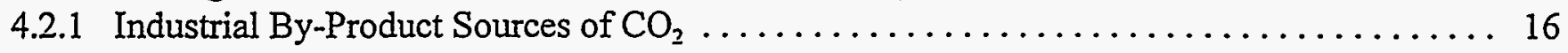




\subsection{Introduction}

Injection of carbon dioxide $\left(\mathrm{CO}_{2}\right)$ into oil fields containing high-viscosity crude is one of the more successful enhanced oil recovery (EOR) techniques recently applied. $\mathrm{CO}_{2}$ is injected into an oil field under high pressure to form a miscible bank of gases that decreases the viscosity of the oil. The process uses a concurrent, alternating, or subsequent injection of water to sweep the oil toward producing wells.

Active $\mathrm{CO}_{2}$ miscible EOR projects have increased from just 17 in 1980 to 54 currently. Over the same period, EOR production from these projects has increased fivefold, from 21,532 to 161,486 barrels per day. Because of the existing infrastructure in the West Texas area, the number of miscible $\mathrm{CO}_{2}$ enhanced oil recovery projects is expected to grow. The existing infrastructure makes the expansion of $\mathrm{CO}_{2}$ into other nearby fields economically feasible.

Accompanying the rapid acceptance of the miscible $\mathrm{CO}_{2}$ method by major oil and gas companies, a number of papers have been published in recent years that describe the properties exhibited by oil fields and reservoirs that make them amenable to the application of this technique. In 1992, Rivas et al., presented a paper at the Society of Petroleum Engineers (SPE) Latin-American Conference which proposed a method to rank reservoirs for the application of the $\mathrm{CO}_{2}$ miscible EOR technique. ${ }^{1}$ The ranking was based purely on technical merit and compared specific oil/reservoir systems to a set of optimum parameters. The parameters include API Gravity, oil saturation, reservoir pressure, temperature, the net oil column, reservoir dip, and porosity and permeability.

Under contract to the Department of Energy, Texaco commissioned the analysis described herein to determine the usefulness of $\mathrm{CO}_{2}$ miscible flooding to oil fields in Texas. The analysis uses a methodology adapted by Louisiana State University from the paper published by Rivas et al., that automates the reservoir ranking process and adds an economic component. The report is intended to assist engineers with identifying candidate projects and to plan advanced recovery programs accordingly.

Many large oil companies have already developed their own screening criteria for evaluating and ranking producing properties. However, smaller companies do not have the resources or expertise to undertake such an evaluation and ranking. A major objective of this report is to generate interest among smaller and intermediate sized companies for using this EOR technique in their own fields. To this end, the report identifies fields that have a high probability of technical and economic success by applying a techrical screen based on parameters from the Rivas paper and an economic screen based on a discounted cash flow analysis of each project. The report should also assist DOE staff to plan a proactive and targeted technology transfer campaign.

The technical screen developed by Rivas et al., showed that, on average the best reservoirs for carbon dioxide flooding should contain $36^{\circ} \mathrm{API}$ oil. The reservoir should also exhibit the following properties:

- a temperature of $150^{\circ} \mathrm{F}$;

- a permeability of $300 \mathrm{md}$;

- an oil saturation of 60 percent;

- a reservoir pressure at the initiation of $\mathrm{CO}_{2}$ injection about $200 \mathrm{psi}$ greater than the minimum miscibility pressure; 
- a porosity of 20 percent;

- a net sand thickness of 40 feet; and

- a reservoir dip of 20 degrees.

The technical screen was applied to the Texas reservoirs using the best and worst case parameter values specified in the paper by Rivas et al. An economic screen was then applied to the reservoirs remaining after the technical screen to identify projects that are economically as well as technically viable. The economic screen was based on a simple benefit/cost ratio computed using published field development costs and production potential for each project that passed the technical screen.

Of the 431 Texas reservoirs screened, 211 were found to be potentially profitable, with projected revenues exceeding costs. Only the top 154 reservoirs, however, showed a rate of return greater than 30 percent, while the top ten reservoirs predicted rates of return of at least 80 percent. Six of the top ten were Gulf Coast sandstone reservoirs.

\subsection{Technical Approach}

The ranking of the Texas oil reservoirs used an approach that was presented at the SPE Latin American Conference by Rivas et al., to screen Venezuelan heavy oil fields for the application of miscible $\mathrm{CO}_{2}$-EOR techniques. This approach for ranking reservoirs was automated by Diaz at Louisiana State University and is the method used for this study. ${ }^{2}$

For this study, data on individual reservoirs were acquired for more than 400 large oil fields that currently account for more than 70 percent of annual Texas oil production. Almost half of the screened reservoirs are located in the Gulf of Mexico coastal region, in Texas Railroad Commission Districts one, two, three, and four. Reservoirs included in the study have produced on average about 10 million barrels each and have adequate geologic data available to perform the screening.

Piercement salt dome fields were excluded from the study because their complex structure, limited size, low well count, and high number make them significantly different from the reservoirs targeted for this study. Despite being beyond the scope of this study, it is recognized that these reservoirs also lend themselves to the application of the $\mathrm{CO}_{2}$ enhanced recovery process.

Most of the physical data used in the technical screen are available for reservoirs in common units of measure. The minimum miscibility pressure (MMP), i.e., the lowest pressure at which about 95 percent of the contacted oil is recovered at a given temperature, is the exception. Oil and carbon dioxide are not generally directly miscible, but become so through the leaching of light hydrocarbons from the crude mixture. In other words the light hydrocarbons become gaseous. Reservoir temperature, oil composition, and carbon dioxide composition are all factors that determine MMP. Observable factors that can be used to determine MMP include:

1. MMP vs. temperature;

2. MMP vs. temperature and the molecular weight of $\mathrm{C}_{5_{+}}$(Pentanes and higher);

3. MMP vs. temperature and API gravity;

4. MMP vs. carbon dioxide density and $\mathrm{C}_{5+}$ composition; 
5. MMP vs. detailed distribution of molecular size and structure;

6. MMP vs. API gravity, oil composition, and carbon dioxide purity.

Temperature and hydrocarbon distribution generally provide the most satisfactory predictions of MMP and are the most useful for initial estimates.

The remainder of the document is organized into the following sections:

Part 2.0 Field Application Review. Approximately 54 field/pilot projects are reviewed with major conclusions listed.

Part 3.0 Texas Reservoir Database. This data base was derived primarily from the hearings files of the Railroad Commission of Texas and is the one to which the technical and economic screens are applied.

Part 4.0 Screening Criteria. The technical screening model is described, sources of carbon dioxide by Texas County are presented, major assumptions are listed, and the results of the economic screen are discussed.

\section{Part 5.0 Conclusions.}




\subsection{Field Applications Review}

The Oil and Gas Journal reports that there are 54 active miscible carbon dioxide projects active in the United States, and this number is expected to grow. ${ }^{3}$ Encouraging field results together with knowledge gained from ongoing projects have contributed to this growth. Recent innovations in miscible $\mathrm{CO}_{2}$ recovery implemented by the oil industry are summarized by Diaz. ${ }^{4}$ They describe intensive investment in infrastructure to develop and transport carbon dioxide to the main producing regions. The main region of $\mathrm{CO}_{2}-\mathrm{EOR}$ application is currently the Permian Basin of New Mexico and West Texas, using carbon dioxide transported via pipeline from the McElmo Dome and Sheep Mountain Reservoirs in the Rockies and Bravo Dome in Mississippi. $\mathrm{CO}_{2}$-EOR projects are also in progress in Mississippi and Louisiana, with $\mathrm{CO}_{2}$ transported from the Jackson Dome (Mississippi). Oklahoma $\mathrm{CO}_{2}$-EOR projects use $\mathrm{CO}_{2}$ obtained from a fertilizer plant located in Enid, $\mathrm{OK}$, while in the Texas Panhandle, $\mathrm{CO}_{2}$ is supplied by the Labarge Gas Processing Facility operated by Exxon.

\subsection{Miscible Field and Pilot Projects}

A good compilation of information about projects involving displacement with carbon dioxide in sandstone reservoirs is provided in Hadlow, R.E., "Update of Industry Experience with $\mathrm{CO}_{2}$ Injection" (1992); Goodrich, J. H., "Review and Analysis of Past and Ongoing Carbon Dioxide Injection Field Tests," (1980); Brock, W. R. and Bryan, L. A., "Summary Results of $\mathrm{CO}_{2}$-EOR Field Tests, 1972-1987," (1989); and Mungan, N., "An Evaluation of Carbon Dioxide Flooding," (1991). To facilitate the analysis a comparison of several projects with all the information obtained from published sources is summarized in Table 2.1.1. The following conclusions were drawn from a close analysis of the information presented in Table 2.1.1.

- Miscible $\mathrm{CO}_{2}$ injection is a reliable enhanced oil recovery method because numerous field tests have yielded considerable knowledge about the process. Process design parameters have been established and prediction techniques have been improved. Cost estimates are more reliable and $\mathrm{CO}_{2}$ is more easily accessible than in the early years of the process. In addition, specialized equipment and techniques are now commercially available.

- Recovery results are encouraging, even though it is difficult to precisely quantify the expected final recovery due to the fact that many projects are still under development.

- Miscible $\mathrm{CO}_{2}$-EOR has worked well in waterflooded and primary depleted reservoirs, and in reservoirs with wide ranges of original oil-in-place (OOIP). However, the remaining oil saturation in a reservoir must be high enough to justify the miscible displacement technique. 
Table 2.1.1. Summary of Field and Pilot Applications of the Carbon Dioxide Miscible Displacement in Waterflooded Sandstone Reservoirs (Ref. 3,34-55)

\begin{tabular}{|c|c|c|c|c|c|c|c|c|c|c|c|c|c|c|c|c|c|}
\hline & & & & & & No. Y & lells & & & & & & & & & & \\
\hline Field & Operator & State & County & date & $\begin{array}{l}\text { Area, } \\
\text { acres }\end{array}$ & Prod. & In]. & Pay Zone & $\begin{array}{l}\text { Rock } \\
\text { Type }\end{array}$ & $\begin{array}{l}\text { Por } \\
\%\end{array}$ & $\begin{array}{l}\text { Perm. } \\
\text { Md }\end{array}$ & $\begin{array}{c}\text { Depth } \\
\text { feet }\end{array}$ & $\begin{array}{c}\text { Grav. } \\
\text { API }\end{array}$ & $\begin{array}{c}\text { Visc. } \\
\text { F }\end{array}$ & $\underset{F}{\text { Iemp }}$ & Prod. & Matur. \\
\hline
\end{tabular}

DOCUMENTED FIELD OR RESERVOIR WIDE PROJECTS

\begin{tabular}{|l|l|l|l|}
\hline Lost Soldier & Amoco & Wr & Sweetwater
\end{tabular}

North Ward Estes

Amoco $\quad$ WY Carbon, Sweetwater

Rangely Weber Sand

Chevron

TX Ward

Ford Geraldine

Twofreds

Chevron $\quad$ CO Rio Blanco

Conoco
Enron O\&G

Little Creek Field

Port Neches

Oxy USA

Shell

TX Reeves \& Culberson

TX Loving, Ward, Reeves

\begin{tabular}{|l|r|r|r|r}
\hline $10 / 86$ & 1400 & 28 & 55 & Tensleep \\
\hline
\end{tabular}

$\begin{array}{lllll}3 / 89 & 3840 & 190 & 194 & \text { Yates }\end{array}$

$10 / 8615000204200$ Weber

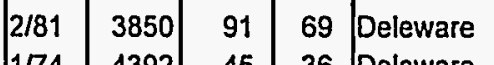

\begin{tabular}{ll|lll}
$1 / 74$ & 4392 & 45 & 36 & Delaware
\end{tabular}

Ponaco

DOCUMENTED PILOT PRIOJECTS

\begin{tabular}{|l|l|c|l|}
\hline Garber & Arco & OK & Garfield \\
West Sussex Unit & Conoco & WY & Johnson \\
Quarantine Bay & Chevron & LA & Plaquemines \\
Rock Creek & Pennzoil & WW & Roane \\
\hline
\end{tabular}

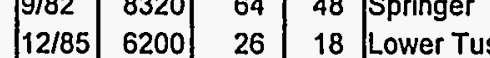

MS Lincoln \& Pike

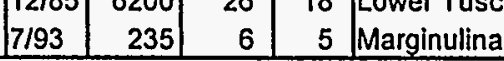

\begin{tabular}{|l|r|r|r|r|l|r|l|l|}
\hline Sand & 9.9 & 31 & 5000 & 35.0 & 1.30 & 178 & WF & HF \\
Sand & 10.0 & 20 & 6000 & 35.0 & 1.16 & 163 & WF & NC \\
Sand & 16.0 & 37 & 2600 & 36.0 & 1.40 & 83 & WF & JS \\
Sand & 12.0 & 10 & 6000 & 35.0 & 1.70 & 160 & WF & JS \\
Sand & 23.0 & 64 & 2680 & 40.0 & 1.40 & 83 & PrimMF & HF \\
Sand & 19.5 & 32 & 4900 & 36.0 & 1.50 & 105 & WF & NC \\
Sand & 13.0 & 44 & 9400 & 38.0 & 1.20 & 148 & WF & HF \\
Sand & 23.0 & 33 & 10750 & 39.0 & 040 & 248 & WF & HF \\
Sand & 30.0 & 750 & 5800 & 34.6 & 3.28 & 165 & WF & JS \\
\hline
\end{tabular}

\section{FIELD OR RESERVOIR WIDE PROJECTS}

\begin{tabular}{|l|l|l|l|}
\hline Sho-Vel-Tum & ARCO & OK & Stephens \\
Citronelle & Citronelle & AL & Mobile \\
Rose City North & George Brown & TX & Orange \\
Rose City North & George Brown & TX & Orange \\
Tinsley & Pennzoil & MS & Yazoo \\
Hansford Marmaton & Stanberry Oil & TX & Hansford \\
Oliva & Shell & MS & Pike \\
Paradis & Texaco & LA & St. Charles \\
Paradis & Texaco & LA & St. Charles \\
Paradis & Texaco/MPV & LA & St. Charles \\
ElMar & Union Royalty & TX & Loving \\
\hline
\end{tabular}

\begin{tabular}{|l|r|r|l|l}
\hline $10 / 81$ & 38.3 & 9 & 4 & Crews \\
$9 / 82$ & 9.6 & 3 & 1 & Shannon \\
$10 / 81$ & 57 & 2 & 1 & 4 sand \\
$10 / 76$ & 20 & 2 & 6 & Big Injun \\
\hline
\end{tabular}

\begin{tabular}{|l|r|r|r|r|r|r|l|l|} 
Sand & 17.0 & 57 & 1950 & 47.0 & 2.10 & 95 & WF & Term \\
Sand & 19.5 & 28.5 & 3000 & 39.0 & 1.37 & 104 & WF & Term \\
Sand & 26.4 & $0-1000$ & 8120 & 32.0 & 0.99 & 183 & Prim & NC \\
Sand & 21.7 & 19.3 & 2050 & 43.0 & 3.20 & 73 & WF & HF \\
\hline
\end{tabular}

EI Mar

Union Royalty TX Loving

\begin{tabular}{|l|r|r|}
\hline $9 / 82$ & 1100 & 4 \\
$5 / 84$ & 1680 & 42 \\
$1 / 83$ & 900 & 8 \\
$1 / 83$ & 900 \\
$11 / 81$ & 1338 & \\
$6 / 80$ & 2010 & \\
$10 / 87$ & 1280 \\
$2 / 82$ & 347 \\
$1 / 88$ & 44 \\
$5 / 90$ & 102 & \\
$4 / 94$ & & 1 \\
\hline
\end{tabular}

\begin{tabular}{|r|r|l|}
\hline 5 & 45 & Sims \\
8 & 10 & Rodessa \\
8 & 5 & Hackberry \\
8 & 5 & Hackberry \\
6 & 10 & Perry \\
9 & 10 & Marmaton \\
7 & 5 & Lower Tuscaloosa \\
7 & 6 & Lower $9000 \mathrm{ft}$ \\
1 & 1 & $9500 \mathrm{ft}$ \\
1 & 1 & $10000 \mathrm{ft}$ \\
7 & 7 & Delaware
\end{tabular}

\begin{tabular}{|c|c|c|c|c|c|c|c|c|}
\hline Sand & 16.0 & 70 & 6200 & 30.0 & 3.30 & 115 & WF & $\mathrm{HF}$ \\
\hline Sand & $10-16$ & 5.75 & 11000 & 42.0 & 46.00 & 210 & Prim NF & PP \\
\hline Sand & 37.0 & 4500 & 8200 & 37.0 & 2.00 & 180 & WF & $\mathrm{HF}$ \\
\hline Sand & 37.0 & 4500 & 8200 & 37.0 & 2.00 & 180 & WF & HF \\
\hline Sand & 26.4 & 49 & 4800 & 39.0 & 1.50 & 175 & WF & Term \\
\hline Sand & 18.1 & 48 & 6500 & 44.0 & 1.56 & 142 & Prim & $\mathrm{HF}$ \\
\hline Sand & 26.0 & 50 & 10500 & 39.0 & 0.34 & 250 & WF & NC \\
\hline Sand & 26.0 & 770 & 10400 & 37.0 & 0.50 & 205 & Prim & $\mathrm{HF}$ \\
\hline Sand & 24.0 & 252 & 9800 & 38.0 & 35.00 & 192 & Prim & $\mathrm{HF}$ \\
\hline Sand & 26.0 & 162 & 11400 & 38.5 & 0.30 & 192 & Prim & $\mathrm{HF}$ \\
\hline Sand & 21.8 & 24 & 4500 & 40.5 & & 97 & PrimMNF & Js \\
\hline
\end{tabular}

PILOT PROJECTS

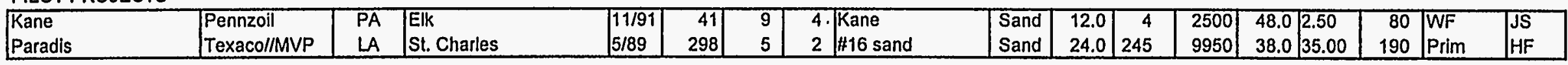


Table 2.1.1. Summary of Field and Pilot Applications of the Carbon Dioxide Miscible Displacement in Waterflooded Sandstone Reservoirs (Ref. 3,34-55) (Continued)

\begin{tabular}{|c|c|c|c|c|c|c|c|c|c|c|c|c|c|c|c|c|c|}
\hline Field & $\begin{array}{l}\text { So } \\
\text { start } \\
\%\end{array}$ & $\begin{array}{l}\text { So } \\
\text { end } \\
\%\end{array}$ & $\begin{array}{c}\text { Total } \\
\text { Prod. } \\
\text { b/d }\end{array}$ & $\begin{array}{l}\text { Enh. } \\
\text { Prod. } \\
\text { b/d }\end{array}$ & $\begin{array}{l}\text { Project } \\
\text { Eval. }\end{array}$ & Profit & $\begin{array}{l}\text { Project } \\
\text { Scope }\end{array}$ & Ref. & $\begin{array}{c}\text { OOIP } \\
\text { MMBIs }\end{array}$ & $\begin{array}{c}\text { Swc } \\
\%\end{array}$ & $\begin{array}{l}\text { Net } \\
\text { Pay } \\
\text { Feet }\end{array}$ & $\begin{array}{c}\text { Space } \\
\text { Acresl } \\
\text { Well }\end{array}$ & $\begin{array}{c}\mathrm{CO}_{2} \text { Inj. } \\
\mathrm{Mmscf} \\
\text { day }\end{array}$ & $\begin{array}{r}\text { MMP } \\
\text { psi }\end{array}$ & $\begin{array}{c}\text { Gross } \\
\text { Mscfl } \\
\text { bbl }\end{array}$ & $\begin{array}{l}\text { Net } \\
\text { Mscfl } \\
\text { bbl }\end{array}$ & $\begin{array}{c}\mathrm{CO}_{2} \\
\text { Source }\end{array}$ \\
\hline
\end{tabular}

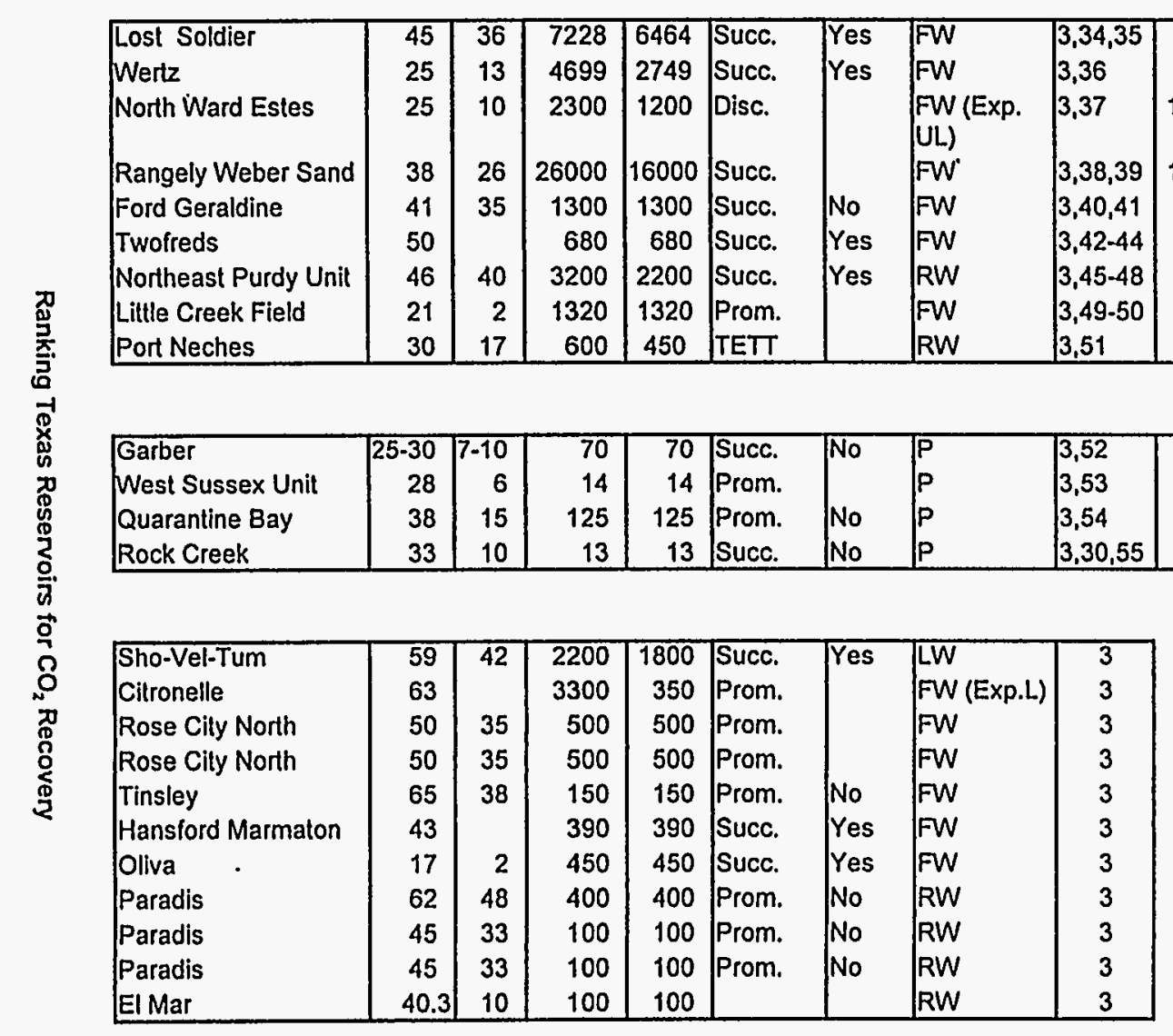

\begin{tabular}{|l|l|l|r|r|r|r|l|l|}
\hline Kane & 70 & 40 & 35 & 10 & TETT & & $P$ & 3 \\
Paradis & 44 & 24 & 325 & 325 & Prom. & & $P$ & 3 \\
\hline
\end{tabular}

\begin{tabular}{|r|r|r|}
105.0 & & 23 \\
1280.0 & 50 & 11 \\
1578.0 & 28 & $250-300$ \\
83.0 & 35 & 25 \\
51.0 & 43 & 25 \\
225.0 & 18 & 40 \\
101.0 & 56 & 30 \\
12.5 & 20 & 30 \\
\hline
\end{tabular}

\begin{tabular}{|l|l|}
\hline 8 & 10 \\
10 \\
20 \\
\hline \\
& 20 \\
5 & 40 \\
5 & 40 \\
0 & 40 \\
0 & 40 \\
\hline 0 & 40 \\
\hline
\end{tabular}

\begin{tabular}{r|r|}
76.0 & 2350 \\
195.0 & 937 \\
170.0 & 3000 \\
20.0 & 900 \\
9.0 & 2330 \\
12.8 & 2100 \\
4.0 & 4500 \\
4.3 & 3310
\end{tabular}

\begin{tabular}{|r|r|l|}
\hline 13 & & Shute Creek Plant \\
$15-19$ & & Shule Creek Plant \\
12 & 4.0 & C02 Dome \\
$12-17$ & $3-8$ & Shute Creek Plant \\
10 & 6.0 & Gas Plant, $\mathrm{CO}_{2}$ domes \\
12 & 9.6 & Mivida gas plant \\
$7-10$ & $4-6$ & Fertilizer plant \\
27 & 13.0 & \\
& & Industrial source \\
\hline
\end{tabular}

\begin{tabular}{|l|l|l|l|l|l|r|r|l|}
\hline 0.6 & 30 & 21 & 10 & 1.8 & 1075 & 6.3 & & Fertilizer plant \\
0.2 & 27 & 22 & 10 & 0.8 & 1550 & 12.9 & & McCallum field \\
1.1 & 23 & 15 & 10 & 1.4 & 3480 & 2.57 & & New Orleans plant \\
0.7 & & 31 & 10 & 0.8 & 1000 & 13 & 9.0 & \\
\hline
\end{tabular}

\section{ABBREVIATIONS}

Project Maturity

JS: Just started

HF: Half finished

NC: $\quad$ Near completion

C: $\quad$ Completed

PP: Postponed

Term: Terminated

Previoụs Production

Prim.: Primary

WF: Waterflooding
Project Evaluation

TETT: Too early to tell

Prom.: Promising

Succ.: Successful

Disc.: Discouraging

\section{Project Scope}

P: $\quad$ Pilot

FW: $\quad$ Field wide

LW: Lease wide

RW: $\quad$ Reservoir wide

Exp. UL: Expansion unlikely

Exp. L: Expansion likely 
Table 2.1.1. Summary of Field and Pilot Applications of the Carbon Dioxide Miscible Displacement in Waterflooded Sandstone Reservoirs (Ref. 3,34-55) (Continued)

\begin{tabular}{|c|c|c|c|c|c|}
\hline Field & $\begin{array}{c}\text { Injection } \\
\text { Pattern }\end{array}$ & $\begin{array}{c}\mathrm{CO}_{2} \\
\text { Injected } \\
\text { HCPV }\end{array}$ & $\begin{array}{c}\text { Oil } \\
\text { Recov. } \\
\% \text { OOIP }\end{array}$ & $\begin{array}{c}\mathrm{CO}_{2} \text { Injection } \\
\text { Mechanism }\end{array}$ & $\begin{array}{c}\text { Disposition } \\
\text { Environment }\end{array}$ \\
\hline
\end{tabular}

\begin{tabular}{|c|c|c|c|c|c|c|}
\hline $\begin{array}{l}\text { Lost Soldier } \\
\text { Wertz } \\
\text { North Ward Estes } \\
\text { Rangely Weber Sand } \\
\text { Ford Geraldine } \\
\text { Twolreds } \\
\text { Northeast Purdy Unit } \\
\text { Little Creek Field } \\
\text { Port Neches }\end{array}$ & $\begin{array}{l}5 \text { spot } \\
5 \text { spot/line dr. } \\
5 \text { spot } \\
5 \text { spot } \\
5 \text { spotline dr. } \\
5 \text { spot } \\
1 / 4 \text { of } 9 \text { spot } \\
5 \text { spot }\end{array}$ & $\begin{array}{l}60 \\
38 \\
30 \\
30 \\
40 \\
30\end{array}$ & $\begin{array}{l}10.0 \\
9-10 \\
8.0 \\
2-7 \\
13.0 \\
9.0 \\
7.5 \\
\\
19.0 \\
\end{array}$ & $\begin{array}{l}\text { WAG } \\
\text { WAG 1:1 (1.5\% ea.) } \\
\text { WAG 1:1 (2.5\% ea.) } \\
\text { WAG 1:1 + water } \\
\text { C01 slug + brine } \\
\text { Slug + WAG + flue gas } \\
\text { Slug + WAG } 3: 1 \\
\text { C02 slug } \\
\text { WAG } \\
\end{array}$ & $\begin{array}{l}\text { Eolian deposit } \\
\text { Tidal flat to lagunal } \\
\text { Deep water fan channel } \\
\text { Deep water fan channel } \\
\text { Shallow marine }\end{array}$ & $\begin{array}{l}\text { Good areal, poor vertical efficiency } \\
\text { Dykstra Parsons, D.P. }=0.8, \text { good areal efficiency } \\
\text { D.P. }=0.85, O G C a p, K v / K h=0.10 \\
\text { Dip }=6 / 15-300, O G \text { Cap, Kv/Kh }=0.25 \cdot 0.50 \\
\text { Good vertical \& poor areal sweep efficiecy } \\
\text { Dystra Parsons }=0.5 \\
\text { Dip }=80\end{array}$ \\
\hline \begin{tabular}{|l} 
Garber \\
West Sussex Unit \\
Quarantine Bay \\
Rock Creek
\end{tabular} & $\begin{array}{l}5 \text { spot } \\
\text { Inv. } 4 \text { spot } \\
4 \& 5 \text { spot }\end{array}$ & \begin{tabular}{|l|}
35 \\
30 \\
18.9 \\
48 \\
\end{tabular} & \begin{tabular}{|l|}
14.0 \\
7.8 \\
16.9 \\
11.0 \\
\end{tabular} & $\begin{array}{l}\text { Slug + chase water } \\
\text { Slug + chase water } \\
\text { WAG 1:1/2:1, } 14 \text { cycles } \\
\text { Slug + chase water }\end{array}$ & $\begin{array}{l}\text { Deltaic \& shallow marine } \\
\text { Inner deltaic }\end{array}$ & $\begin{array}{l}\text { Lateral reservoir variation, dip }<50 \\
\text { Dip }=60 \\
\text { Dip }=40 \\
\text { OGCap, Kv/Kh }=0.79\end{array}$ \\
\hline
\end{tabular}


- Recovery efficiencies range from 2 to 19 percent of OOIP, and the net amount of $\mathrm{CO}_{2}$ required to recover an incremental barrel of oil varies from 3 to 13 thousand standard cubic feet (Mscf). The average recovery for documented cases is 10.8 percent of OOIP and the average $\mathrm{CO}_{2}$ utilization ratio is $7.2 \mathrm{Mscf}$ of carbon dioxide per incremental barrel of oil. These values agree fairly well with ones reported by Martin for application of $\mathrm{CO}_{2}$ miscible displacement in different types of reservoir rock. ${ }^{5}$

- The most common well spacing is 40 acres per well, even though some applications--especially the pilot tests--had spacing of 10 acres per well. The preferred configuration was the 5-spot, sometimes combined with a line drive. The predominant injection mechanism was a 1:1 water alternating with $\mathrm{CO}_{2}$, with innovations such as hybrid and tapered injection sometimes used. Injected $\mathrm{CO}_{2}$ volumes varied between 19 and 60 percent of hydrocarbon pore volume (HCPV), with an average injection rate of 36 percent HCPV.

- Even though it was not possible to find complete information about the depositional environment of the reservoir rock, available data indicate reservoirs of diverse depositional environments, but all with relatively good continuity.

- Reported reservoir dips varied between 4 and 30 degrees, with a clear predominance of reservoirs with a low dip angle. Several of the reservoirs also had initial gas caps.

- The most common problems encountered during a project were surface and downhole equipment corrosion which was reported in 58 percent of the cases reviewed, followed by low vertical efficiency (50 percent of the cases), and asphaltene or paraffin precipitation ( 30 percent of the cases). It is also evident that the industry has gained a lot of experience dealing with these problems and had found ways to prevent or minimize them.

- Project profitability was not always reported, but about half of the reported cases were profitable. Obtaining $\mathrm{CO}_{2}$ was usually responsible for a good portion of the project cost. Most of the reported sources of $\mathrm{CO}_{2}$ were nearby industrial plants, which allowed for relatively easy transportation.

- Using the average estimated carbon dioxide utilization rate and an assumed cost of $\$ 0.70$ per Mscf, the average recovery cost is about $\$ 5$ per incremental barrel of oil.

- It is evident that in many of these projects, $\mathrm{CO}_{2}$ injection rates were adjusted to maximize process efficiency. To do this, it was necessary to have good monitoring and maintenance programs so that the process performance could be assessed during the project life.

- More research is needed into methods for improving vertical sweep efficiency. Efficient vertical sweep requires a knowledge of reservoir geometry, and vertical and lateral geo-continuity and characteristics.

- From the point of view of field operations, many factors can be improved to reduce costs and therefore enhance project economics. These include: the optimized use of existing wells; injecting gels or polymers to improve areal sweep efficiency; injection of fluids at selected vertical intervals 
in the well bore; reutilization of existing facilities; optimization of pressure build up in the reservoir; $\mathrm{CO}_{2}$ recycling; and finally, application of technologies like horizontal drilling. Improvement in these factors could significantly increase the volumes of oil recovered and decrease the volume of $\mathrm{CO}_{2}$ injected, therefore improving project profitability.

\subsection{Texaco's Port Neches Field Test}

In 1992, DOE and Texaco entered into a cooperative agreement to establish the viability of using miscible $\mathrm{CO}_{2}$-EOR technology on Fluvial Dominated Deltaic (FDD) reservoirs, a large number of which are located along the Gulf Coast. This work was undertaken, in part, because primary and secondary recovery usually leaves more than 50 percent of the original oil in place behind. Texaco's project demonstrated the viability of the process in the Marginulina reservoir in the Port Neches field, Orange County, Texas. A by-product $\mathrm{CO}_{2}$ source was used in the project and transported via pipeline from a nearby gas processing plant.

\subsubsection{Relevance of the Technical Demonstration}

The results of the demonstration project are expected to validate the use of a miscible $\mathrm{CO}_{2}$ flood in other FDD reservoirs, particularly those reservoirs that have previously been waterflooded or that have a weak waterdrive, and provide a basis on which the decision to use the process in similar reservoirs can be made. Other petroleum operators will be able to predict the amount of incremental oil recovery that can be expected based on the experiences and results gained from this project. The project will demonstrate the impact of reservoir heterogeneities and the importance of reservoir characterization. The project will also provide a basis for estimating the applicability of the technology to highly heterogeneous clastic reservoirs other than FDD reservoirs. The project also demonstrated the effectiveness of a horizontal $\mathrm{CO}_{2}$ injection well, noting the improvements in sweep efficiency of the residual oil column.

\subsubsection{Encouraging Private Sector Implementation}

The results in the Port Neches field will enable other oil and gas companies to assess the practicability and appropriateness of using $\mathrm{CO}_{2}$-EOR in other reservoirs of this category. This technology is expected to have widespread applicability among other FDD reservoirs because it is common for these reservoirs to have relatively weak primary drive mechanisms and high remaining oil saturations after secondary recovery techniques, such as waterflooding, have been applied. Factors that could affect a company's decision to use this technology may include:

1. The incremental oil recovery expected by applying this process.

2. The availability and cost of $\mathrm{CO}_{2}$, including transportation costs.

3. The costs of facilities, well workovers, drilling additional injection and/or producing wells, and incremental operating costs associated with the project.

4. The $\mathrm{CO}_{2}$ recycle compression cost. 
5. The overall project economics.

Based on the degree of success and profitability of the project, other petroleum operators that have similar reservoirs will be able to make intelligent decisions concerning the merit of using the $\mathrm{CO}_{2}-\mathrm{EOR}$. 


\subsection{Texas Reservoir Database}

Appendix A provides a full description of the data elements in the Texas Reservoir Database developed for this project. Much of the information contained in the data base was derived from the hearings files of the Texas Railroad Commission. Commission data that proved particularly informative include unitization, injection, maximum efficient recovery, field rules, and date of discovery files. Additional sources of numerical and descriptive data include:

1. Oil and gas reservoir files compiled by the U.S. Department of Energy, Energy Information Agency, Dallas Field Office.

2. Compilations of field studies published by various regional geological societies, the American Association of Petroleum Geologists, and the Society of Petroleum Engineers.

3. Publications of the Texas Railroad Commission, including the 1981 Annual Report and a survey of secondary and enhanced recovery operations.

4. Publications by the Rand Corporation and the U.S. Department of Energy on major oil and gas fields in the United States and evaluations of fields targeted for enhanced recovery.

Data were supplemented with information provided by individual operating companies. All of the above sources are documented in the Bibliography at the end of this report.

The accuracy of publicly available quantitative reservoir data varies greatly. Different sources commonly gave different values for the same type of data. Where great discrepancies exist, data values were selected on the basis of known geologic criteria and within the context of the overall information available on a reservoir. Data were weighted in favor of records that reflected greater geological and engineering research efforts. 


\subsection{Screening Criteria}

This section provides a description of the technical criteria used for the technical screen performed on the Texas Reservoir Database. It is followed by a section outlining the calculation of the cost of obtaining $\mathrm{CO}_{2}$ and its likely sources. The economic screen is then described and assumptions and limitations of the study are discussed. Finally, the results of the technical and economic screen are presented.

\subsection{Technical Criteria (Calculation of Technical Ranking Factor)}

The Rivas study defined the optimum reservoir characteristics by performing numerical simulation on a base case to determine the value of a selected set of parameters which maximized oil recovery from the simulated $\mathrm{CO}_{2}$ flood. The base case was assumed to be a 10-year injection program in a five-spot well configuration with 40 acre spacing. The optimum values for the parameters were determined by varying parameter values slightly around starting-values provided by Rivas. Few, if any, reservoirs would exactly match the parameter values of this ideal. The numerical simulation was performed using three off the shelf reservoir simulation models -- a fully compositional simulator, a black oil model, and a semi-analytical predictive model.

In ranking a set of randomly selected oil reservoirs, Rivas determined reservoir parameter values that represent the most extreme, but realistic departures from the optimum. These extreme parameters are combined to define the worst case reservoir. This worst case reservoir, in most cases, would not be one of the actual reservoirs being ranked, but rather would be a hypothetical reservoir and provides a boundary for parameter values. Reservoirs with parameter values which are "outside" the worst case were either eliminated from the analysis or their outlier parameters were assigned the worst case value.

As parameters were varied around their optimum, Rivas noted their effect on the variation in oil recovery. The shape of parameter performance curves suggested that some of the parameters may have more of an effect on performance than others. Parameters that produced a more acute effect on production were considered to be more important than those that have little effect. Rivas assigned weights to the parameters based on their relative effect on production. The most influential parameters were found to be API gravity, oil saturation, and reservoir pressure.

Table 4.1.1 presents the parameters which optimized process performance as given by the numerical simulations discussed above. It also provides the upper limit on the value of a parameter and shows the weight assigned by Rivas based on the relative influence of each parameter on production. Results from the three simulations for the most influential parameters are shown in Figures 4.1.1, 4.1.2, and 4.1.3 taken from Rivas.

Rivas assigned one technical ranking factor for each reservoir by calculating the weighted sum of all the reservoir property parameters. The technical ranking factor was then normalized so that the best reservoir has a factor of 100 , and the worst reservoir has a factor of 0 . 
Table 4.1.1. Optimum Reśervoir Parameters, Upper Limit, and Weighting Factors. ${ }^{(22)}$

\begin{tabular}{c|c|c|c}
\hline Parameter & Optimum & Upper Limit & Weight \\
\hline API Gravity, ${ }^{\circ} \mathrm{API}$ & 37 & 54 & 0.24 \\
Oil Saturation, \% & 60 & 83.1 & 0.20 \\
Pressure/MMP & 1.3 & 1.3 & 0.19 \\
Temperature, ${ }^{\circ} \mathrm{F}$ & 160 & 250 & 0.14 \\
Net Oil Column, $\mathrm{ft}$ & 50 & 300 & 0.11 \\
Permeability, md & 300 & 2500 & 0.07 \\
Dip, degrees & 20 & 20 & 0.03 \\
Porosity, \% & 20 & 35 & 0.02 \\
\hline
\end{tabular}

Source: Rivas, O., Embid, S., and Boliver, F. "Ranking Reservoirs for $\mathrm{CO}_{2}$ Flooding Processes," SPE paper 23641 presented at the 1992 SPE Latin American Petroleum Engineering Conference, Caracas, March 8-11.

This method of ranking reservoirs was used to rank the reservoirs in the Texas Reservoir Database. Several reservoirs were first eliminated from the database because important data, e.g. API gravity, were either missing or questionable. The remaining reservoirs were then ranked using the technical screen procedure described above. Then, the economic screen was applied as described in Section 4.3. The economic screen is heavily dependent on sources and costs of obtaining $\mathrm{CO}_{2}$ which are described in the next section (4.2).

Figure 4.1.1 Average Oil Production as a Percent of Oil Saturation

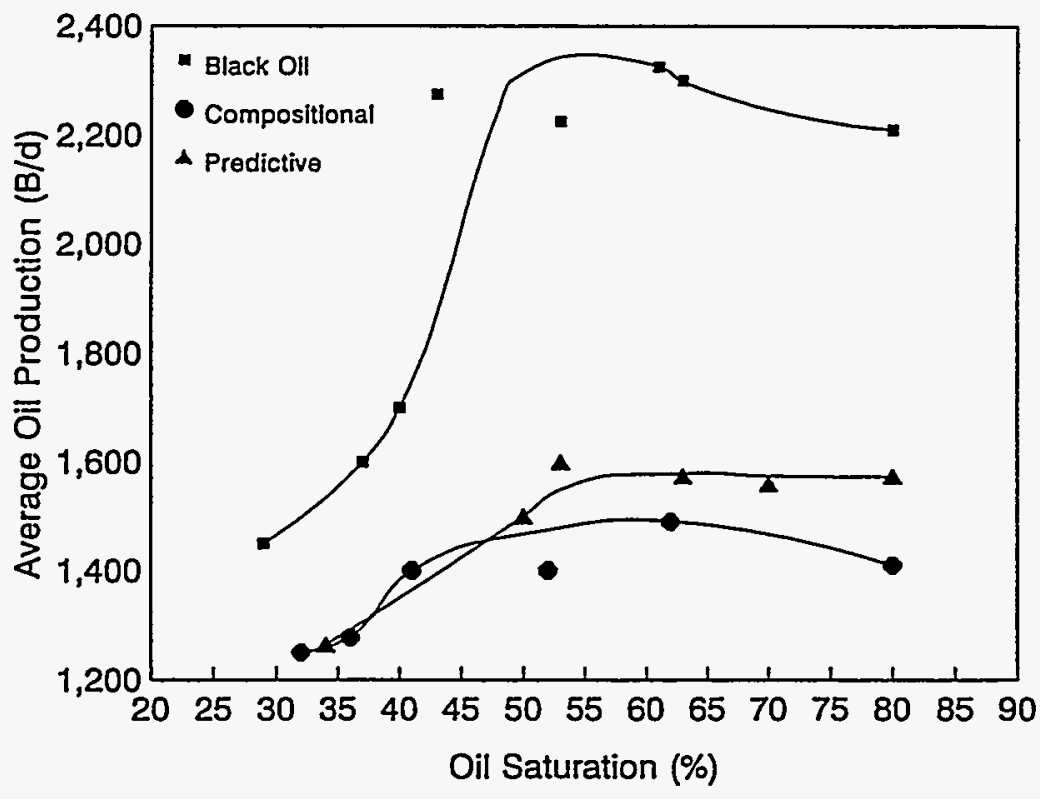


Figure 4.1.2 Average Oil Production as a Function of Pressure Ratio

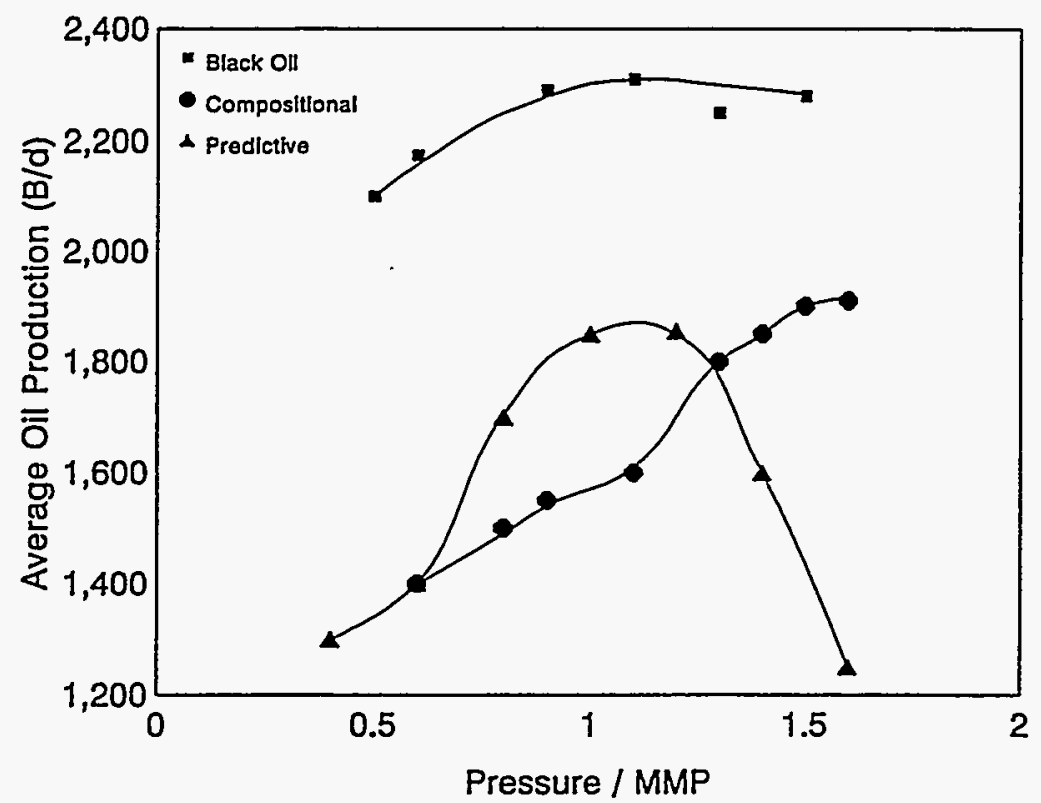

Figure 4.1.3 Average Oil Production as a Function of API Gravity

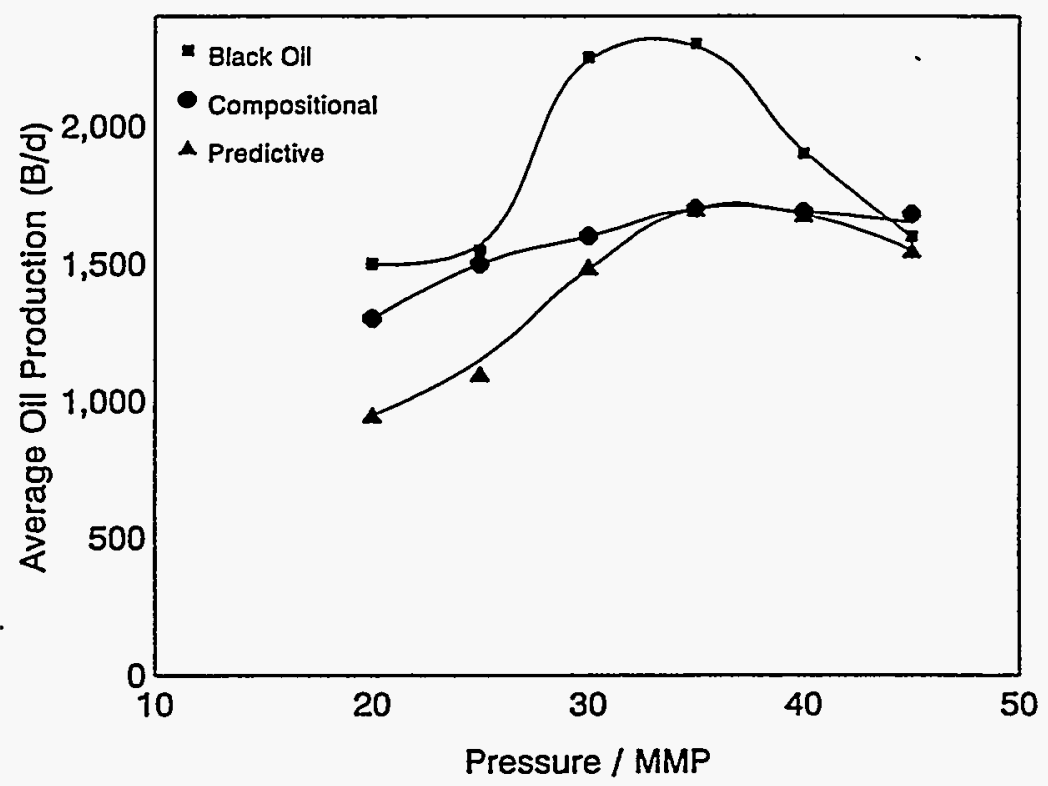




\subsection{Sources of Carbon Dioxide and Cost}

Sources of $\mathrm{CO}_{2}$ were derived primarily from studies performed by Science Applications International Corporation (SAIC) for the Department of Energy, Morgantown Energy Technology Center (METC) ${ }^{6}$. It was assumed that only Permian Basin $\mathrm{CO}_{2}$ demand would be supplied by naturally occurring $\mathrm{CO}_{2}$. All other promising reservoirs, particularly those in the Gulf Coast region, have access to highly pure $\mathrm{CO}_{2}$ produced as a by-product of local industry and natural gas processing plants (Figure 4.2.1).

Miscible $\mathrm{CO}_{2}$-EOR technology has a history of success in the vast West Texas oil fields. However, recent efforts by Texaco, Shell, and others to emulate the West Texas successes on the Gulf Coast have so far proved inconclusive. There are three reasons for the inconclusive results:

1. There are significant differences between the reservoirs in West Texas and those along the Gulf Coast. West Texas $\mathrm{CO}_{2}$-EOR projects are located primarily in carbonate reservoirs with limited faulting, whereas Gulf Coast reservoirs tend to be primarily clastic and highly faulted;

2. A plentiful $\mathrm{CO}_{2}$ source and transportation network brings $\mathrm{CO}_{2}$ to the West Texas fields, whereas the Gulf Coast lacks such a network; and

3. The contrast in the surface environment affects transportation, emission containment, and water disposal options and costs. These effects are shown in Table 4.2.1

Table 4.2.1 Comparative Features Affecting $\mathrm{CO}_{2}$-EOR Design

\begin{tabular}{|c|c|c|c|}
\hline & $\begin{array}{l}\text { West Texas } \\
\text { Features }\end{array}$ & $\begin{array}{l}\text { Gulf Coast } \\
\text { Features }\end{array}$ & $\begin{array}{l}\text { Net Effect on Gulf } \\
\text { Coast } \mathrm{CO}_{2}-\mathrm{EOR}\end{array}$ \\
\hline Reservoir Type & $\begin{array}{l}\text { Carbonate reservoirs } \\
\text { with limited faulting. }\end{array}$ & $\begin{array}{l}\text { Clastic and highly } \\
\text { faulted. }\end{array}$ & $\begin{array}{l}\text { Poor pattern design, limited success in } \\
\text { forecasting oil recovery, } \mathrm{CO}_{2} \text { channeling, } \\
\text { and higher recycle costs. }\end{array}$ \\
\hline $\mathrm{CO}_{2}$ Source & $\begin{array}{l}\text { Large number of } \\
\text { developed natural } \\
\text { supply sources and } \\
\text { integrated network. }\end{array}$ & $\begin{array}{l}\text { One natural supply, a } \\
\text { number of smaller by- } \\
\text { product supplies, limited } \\
\text { pipeline network. }\end{array}$ & $\begin{array}{l}\text { May require developing the } \mathrm{CO}_{2} \text { source } \\
\text { and building a pipeline network. }\end{array}$ \\
\hline Surface Features & $\begin{array}{l}\text { Minimally populated } \\
\text { prairies with low annual } \\
\text { rainfall. }\end{array}$ & $\begin{array}{l}\text { Wetlands, timber-lands, } \\
\text { and farm-land } \\
\text { intermixed with high } \\
\text { density areas with } \\
\text { considerable rain-fall. }\end{array}$ & $\begin{array}{l}\text { Pipelines more expensive in sensitive } \\
\text { areas, water disposal requires } \\
\text { consideration, air pollution may be a } \\
\text { factor. }\end{array}$ \\
\hline
\end{tabular}




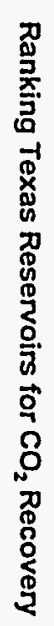

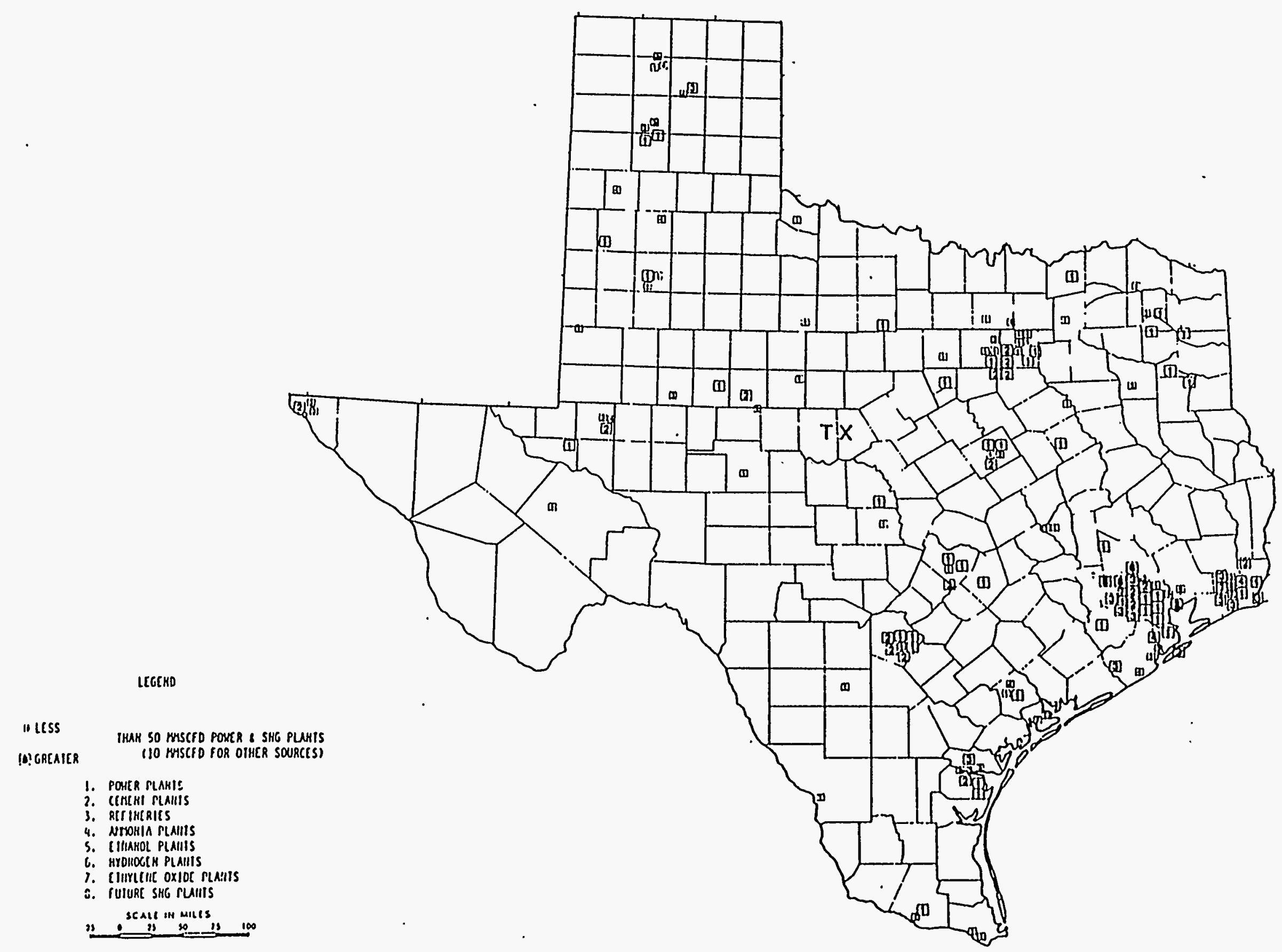


Impurities, such as nitrogen $\left(\mathrm{N}_{2}\right)$ hydrogen sulfide $\left(\mathrm{H}_{2} \mathrm{~S}\right)$, or methane $\left(\mathrm{CH}_{4}\right)$ are common in natural sources of $\mathrm{CO}_{2}$, while nitrogen and carbon monoxide (CO) are common in manmade sources, such as flue gas. The presence of these impurities produces variations in $\mathrm{CO}_{2}$ miscibility pressure and creates safety and production problems. Contamination by $\mathrm{N}_{2}, \mathrm{CO}$, and $\mathrm{CH}$ increases miscibility pressure and therefore requires higher operating pressures. Although contamination by $\mathrm{H}_{2} \mathrm{~S}$ decreases miscibility pressure, this positive effect is more than offset by the additional fail-safe metering and more expensive and corrosion resistant higher carbon steel required to manage the $\mathrm{H}_{2} \mathrm{~S}$. Project economics are substantially improved when a source of $\mathrm{CO}_{2}$ with greater than 95 percent purity is used.

The pressure of $\mathrm{CO}_{2}$ at its source is a critical factor in $\mathrm{CO}_{2}$ transportation and injection costs. At pressures above $1,000 \mathrm{psi}, \mathrm{CO}_{2}$ is a liquid and can be transported relatively cheaply using pumps or a natural pressure drop. Either option is cheaper than the alternative method of purchasing and operating gas compressors. In addition, to get $\mathrm{CO}_{2}$ to the reservoir at a pressure above miscibility pressure generally requires injecting $\mathrm{CO}_{2}$ above 1,000 psi. Raising the pressure from atmospheric pressure to 1,000 psi can cost $\$ 0.10$ to $\$ 0.25$ per Mscf, depending on capital equipment and energy costs.

The only industrial by-product sources that can potentially provide $\mathrm{CO}_{2}$ for a delivered cost less than $\$ 2$ per Mscf are power plants and highly pure sources from ammonia plants and catalytic cracking units. Sources of $\mathrm{CO}_{2}$ in Texas, by county, are listed in Tables 4.2.2, 4.2.3, and 4.2.4. It is assumed that by-product sources of $\mathrm{CO}_{2}$ will on average cost more than natural sources. Because $\mathrm{CO}_{2}$ is a unique input variable, a miscible $\mathrm{CO}_{2}$-EOR project which relies on an industrial by-product source is penalized with a 20 percent cost premium.

Pipelines are the most economical form of transport for large volumes of $\mathrm{CO}_{2}$ over short and long distances (one to 20 miles and more than 150 miles). Truck transport is competitive with pipelines for small volumes (one to $10 \mathrm{MMscf}$ per day) over medium distances. For pilot projects, either truck or rail may be the best method of transport, depending on the availability of transport system equipment, rail facilities, and the volumes of $\mathrm{CO}_{2}$ required. 
Table 4.2.2 Power Plants by County

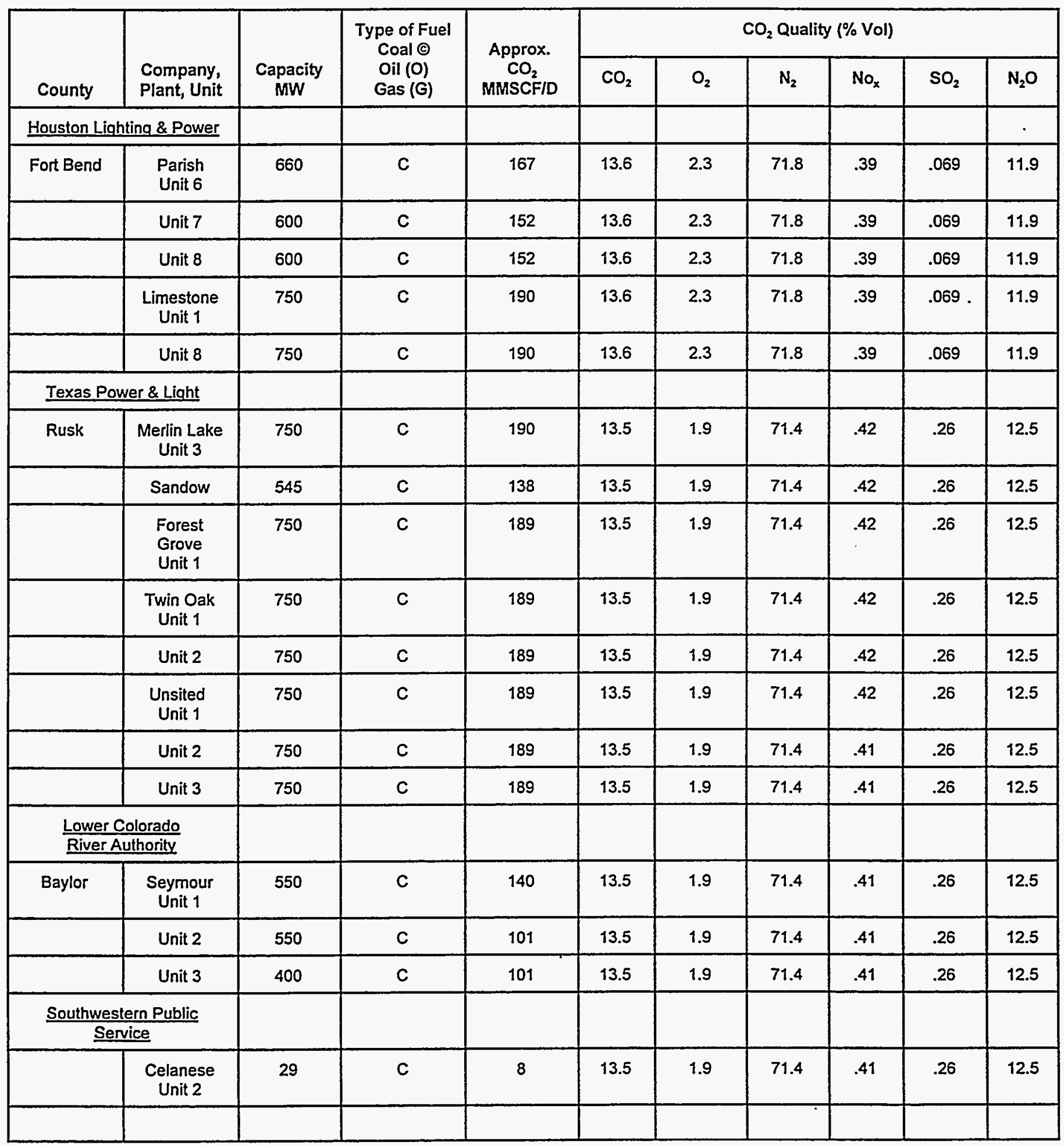


Table 4.2.2 Power Plants by County (Continued)

\begin{tabular}{|c|c|c|c|c|c|c|c|c|c|c|}
\hline \multirow[b]{2}{*}{ County } & \multirow[b]{2}{*}{$\begin{array}{l}\text { Company, } \\
\text { Plant, Unit }\end{array}$} & \multirow[b]{2}{*}{$\begin{array}{c}\text { Capacity } \\
\text { MW }\end{array}$} & \multirow{2}{*}{$\begin{array}{c}\text { Type of Fuel } \\
\text { Coal } \odot \\
\text { Oil (O) } \\
\text { Gas (G) }\end{array}$} & \multirow{2}{*}{$\begin{array}{l}\text { Approx. } \\
\mathrm{CO}_{2} \\
\text { MMSCFIID }\end{array}$} & \multicolumn{6}{|c|}{$\mathrm{CO}_{2}$ Quality $(\% \mathrm{Vol})$} \\
\hline & & & & & $\mathrm{CO}_{2}$ & $\mathrm{O}_{2}$ & $\mathrm{~N}_{2}$ & NO $_{x}$ & $\mathrm{SO}_{2}$ & $\mathrm{H}_{2} \mathrm{O}$ \\
\hline \multicolumn{11}{|c|}{$\frac{\text { Brazos Electric }}{\text { Power Coop }}$} \\
\hline & $\begin{array}{l}\text { San Miguel } \\
\text { Unit } 1\end{array}$ & 400 & c & 101 & 13.5 & 1.9 & 71.4 & .41 & .26 & 12.5 \\
\hline & Unit 2 & 400 & C & 101 & 13.5 & 1.9 & 71.4 & .41 & .26 & 12.5 \\
\hline \multicolumn{11}{|c|}{ Texas Power Pool } \\
\hline & $\begin{array}{l}\text { Gibbons } \\
\text { Creek } \\
\text { Unit } 1\end{array}$ & 400 & c & 101 & 13.5 & 1.9 & 71.4 & .41 & .26 & 12.5 \\
\hline & $\begin{array}{l}\text { Unsited } \\
\text { Unit } 1\end{array}$ & 400 & c & 101 & 13.5 & 1.9 & 71.4 & .41 & .26 & 12.5 \\
\hline & Unit 2 & 400 & c & 101 & 13.5 & 1.9 & 71.4 & .41 & .26 & 12.5 \\
\hline \multicolumn{11}{|c|}{ Public Serv. Brd. } \\
\hline & $\begin{array}{l}\text { Unsited } \\
\text { Unit } 1\end{array}$ & 500 & c & 127 & 13.5 & 2.3 & 71.8 & .39 & .069 & 11.9 \\
\hline Harris & Wharton & 322 & c & 56.5 & 9.1 & 1.7 & 72.1 & - & - & 17.0 \\
\hline \multicolumn{11}{|c|}{$\frac{\text { Lower Colorado }}{\text { River Auth. }}$} \\
\hline Llano & Ferguson & & c & 45.9 & 9.1 & 1.7 & 72.1 & - & - & 17.0 \\
\hline Harris & Clarke & 210 & G & 15.3 & 9.1 & 1.7 & 72.1 & - & - & 17.0 \\
\hline Harris & Clarke & 210 & $\mathbf{G}$ & 15.3 & 9.1 & 1.7 & 72.1 & - & - & 17.0 \\
\hline Harris & Deepwater & 353 & G & 45.9 & 9.1 & 1.7 & 72.1 & - & - & 17.0 \\
\hline Harris & $\begin{array}{l}\text { Green } \\
\text { Bayou }\end{array}$ & 821 & G & 115.3 & 9.1 & 1.7 & 72.1 & - & - & 17.0 \\
\hline Fort Bend & Parish & 2723 & G & $\begin{array}{c}347.2 \\
0.0 \\
89.6\end{array}$ & 9.1 & 1.7 & 72.1 & - & - & 17.0 \\
\hline Galveston & Robinson & 2314 & G & 432.0 & 9.1 & 1.7 & 72.1 & - & - & 17.0 \\
\hline Harris & Webster & 614 & G & 96.5 & 9.1 & 1.7 & 72.1 & - & - & 17.0 \\
\hline
\end{tabular}


Table 4.2.3 Ammonia Plants - by County

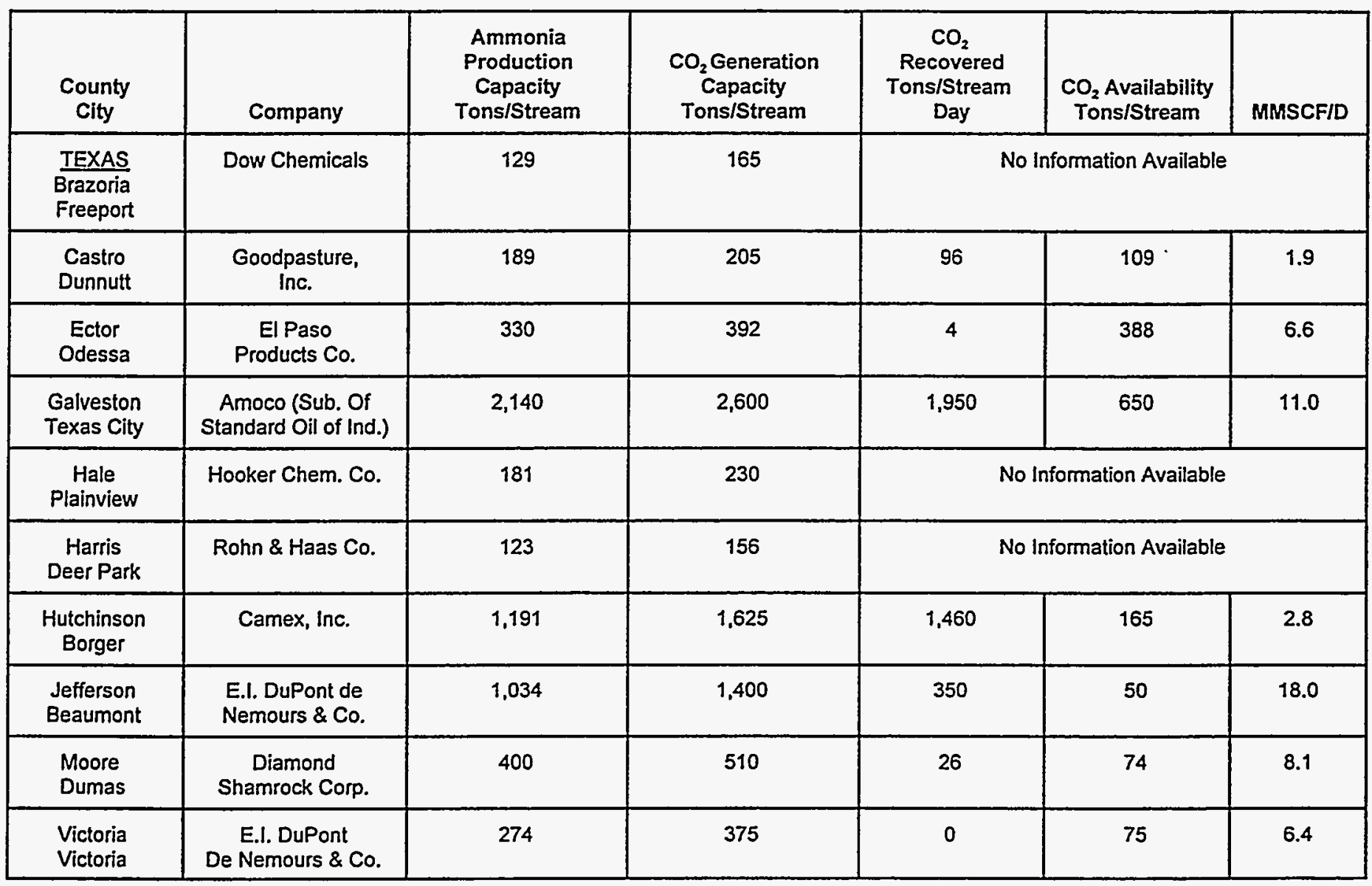

20

Ranking Texas Reservoirs for $\mathrm{CO}_{2}$ Recovery 
Table 4.2.4 List of Fluid Catalytic Cracking Units $\mathrm{CO}_{2}$ Generation Capacity

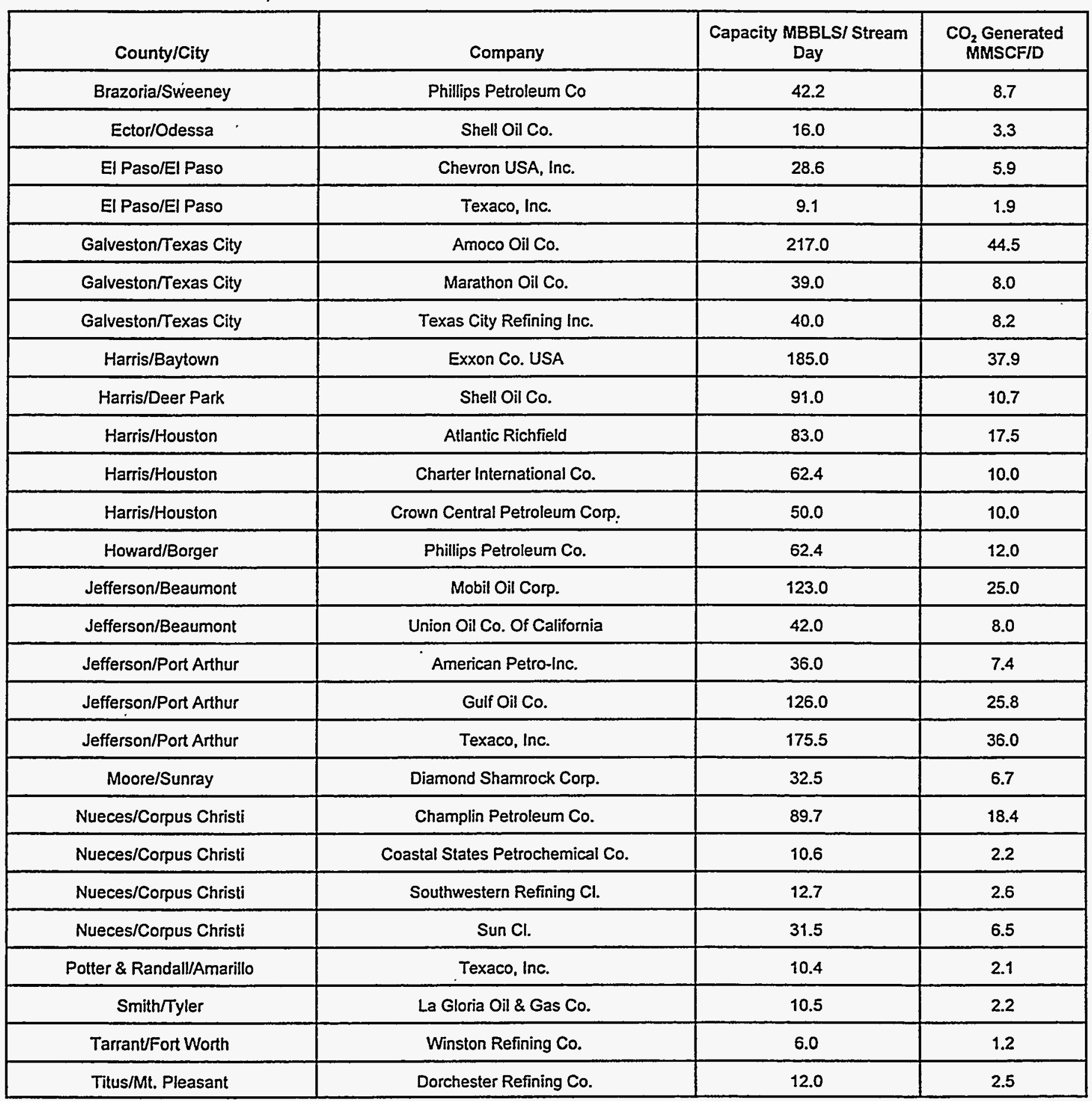




\subsection{Economic Screening Criteria}

The economic screen is a simple discounted cash flow comparison of most of the reservoirs remaining after the technical screening. Economic screening and prioritization are based on the ratio of net revenue (profit) to cost. It was assumed, for the purpose of economic ranking that the technical ranking factor calculated with the technical screen provides a reasonable approximation of a potential oil recovery factor.

The potential oil recovery used in the economic screen is defined as the product of the original oil-in-place, the expected recovery factor for $\mathrm{CO}_{2}$ flooding, and the technical ranking factor. Other parameters used in the economic screen are reservoir area, number of existing wells, depth, and distance to a $\mathrm{CO}_{2}$ source. All capital and operating costs are calculated using equations shown in Table 4.3.1. Major assumptions for the screen are $\mathrm{CO}_{2}$ price, oil price, well spacing, and expected recovery (fraction of OOIP).

Table 4.3.1 Economic Calculation Equations

\begin{tabular}{|c|c|}
\hline Parameter & Definition \\
\hline Gross Revenue & $\begin{array}{l}\text { Gross Revenue }=\text { Recoverable oil } * \text { oil price. } \\
\text { where, } \\
\text { Recoverable oil }=\text { OOIP } * \text { Technical ranking factor } * \text { Recovery factor. }\end{array}$ \\
\hline $\begin{array}{l}\text { Capital cost } \\
\text { o Drilling }(7,8) \\
\text { o Equipment } \\
\text { - } \mathrm{CO}_{2} \text { Pipeline }^{(10,11)} \\
\text { - Separation } \\
\end{array}$ & $\begin{array}{l}\text { New well cost }=\$ 30,340 * \# \text { wells } * \mathrm{e}^{(0.00035 * \text { depth })} \\
\text { Equipment }=8.3125 * \text { depth *\# wells } \\
\text { Pipeline }=[\$ 100,000+(\text { pipeline capacity } \\
\quad \text { where, } \\
\quad \text { pipeline capacity }=6 *(\text { Recoverable oil }) \\
\end{array}$ \\
\hline Operating Costs & Well Operations $=(1,040+0.1462 *$ depth $) * 12 * \#$ wells \\
\hline $\mathrm{CO}_{2} \operatorname{Cost}^{(14,15,16,)}$ & $\mathrm{CO}_{2}$ Costs $=$ Recoverable oil $* 6(\mathrm{Mscf} / \mathrm{B}) *$ price $(\$ / \mathrm{B})$ \\
\hline Net Revenue & Net Revenue $=($ Gross Revenue - Total costs $) *(1.0-$ tax rate $)$ \\
\hline Profit/Cost Ratio & Profit $/$ Costs $=$ Net revenue $/$ Total Costs \\
\hline
\end{tabular}

Source: Equation sources are in parentheses and were extracted from papers listed in the references. 


\subsection{Assumptions and Limitations of the Screening}

In order to rank the reservoirs, it is necessary to have a parameter that can be easily used for comparison of all of the possible reservoirs. Several assumptions based on engineering judgement supported by data and literature review, were made to maintain the manageability of the analysis.

- The maximum expected recovery from the miscible $\mathrm{CO}_{2}-\mathrm{EOR}$ process is 10 percent of original oil in place. The review of the field and pilot applications suggests that this value is technically sound, if not on the conservative side. In this assumption, the kind of processes used for the displacement are not differentiated, and the same annual production profile is used for all reservoirs used in the discounted cash flow.

- The reservoirs possessing better properties for the process are assumed to perform better economically. The technical ranking factor obtained from the technical screening is used to determine the potential recovery factor $(\mathrm{PR})$ that is used to predict reservoir performance.

- Parameter values used in the equations are from published investigations. If any of the parameter values are biased, they are applied to all reservoirs equally and should therefore not introduce bias to any specific reservoir.

- Dip was unknown in most cases and in fact is probably not constant for the largest reservoirs. The reservoirs for which dip was known averaged about 10 degrees, albeit with some extreme variation. For this analysis the dip was set at a constant 20 degrees for all reservoirs.

- Well spacing was assumed to be uniform and constant. Although the areal extent of each reservoir was generally not known, for the screen each reservoir was normalized to equal one five spot on a 40-acre spacing. It was further assumed that all five wells were already equipped and operational. The original oil in place in this normalized reservoir is calculated as the product of net pay, porosity, and oil saturation. Most reservoirs in this study are many times larger than this assumption and most wells would probably not be fully developed or would need to be drilled.

- Operating costs and $\mathrm{CO}_{2}$ costs are reported on an annual basis and are assumed to be constant over the life of a project. The expected life of a project is assumed to be twenty years.

- The cost of using $\mathrm{CO}_{2}$ from non-natural sources is assumed to be 20 percent more expensive than using naturally occurring $\mathrm{CO}_{2}$. 


\subsection{Results of Technical and Economic Screening}

The screening methods described above were used to screen the largest, most productive reservoirs in the State of Texas. Initially the database contained over 500 reservoirs. Over 100 reservoirs were initially eliminated due to a lack of geologic information, leaving 378 reservoirs with sufficient data for the technical screen.

Table 4.5.1 presents the ranking of the 211 reservoirs left after the economic screen was performed. There are two columns with rank numbers. The first column shows the results of the technical screen. The second column shows the result of the economic screen, ranked in order. The economic parameters used in the screen were: recovery factor -10 percent; oil price - $\$ 17 / \mathrm{bbl}$; taxes -15 percent; $\mathrm{CO}_{2}$ costs $-\$ 0.60$ per Mscf.

The screens provide a very fast method of ranking many reservoirs, making sensitivity analysis on key parameters practical. The economic ranking, although simple, appeared to give valid results as most of the current $\mathrm{CO}_{2}$ field applications that were contained in the database placed high in the rankings. That is, the projects that ranked high after the survey are already considered profitable by their operators. 
Table 4.5.1. Ranking of Reservoirs With Positive Net Revenue

\begin{tabular}{|c|c|c|c|c|c|c|c|c|c|c|c|c|c|c|}
\hline FIELD & DEG. API & TEMP, $\mathbf{F}$ & PERM. & So, \% & P/MMP & POR.,\% & PAY & DIP & EOOIP & AREA & WELLS & DEPTH & TECH & ECON \\
\hline KEYSTONE COLBY & 38 & 87 & 3 & 54.87 & 0.95 & 13 & 900 & 10 & 99.70 & 200 & 5 & 3100 & 72.89 & 2.536 \\
\hline VAN WOODBINE & 34 & 140 & 1000 & 75.66 & 0.36 & 29 & 250 & 10 & 85.18 & 200 & 5 & 2700 & 44.94 & 2.428 \\
\hline HASTINGS, W. FRIO & 31 & 160 & 865 & 66.51 & 0.59 & 31 & 163 & 10 & 52.19 & 200 & 5 & 6100 & 57.64 & 2.244 \\
\hline ESPERSON DOME S. CROCKETT & 39 & 200 & 240 & 63.18 & 0.9 & 27 & 176 & 10 & 46.63 & 200 & 5 & 7300 & 77.97 & 2.179 \\
\hline FAIRBANKS FAIRBANKS & 36 & 185 & 2000 & 58.2 & 0.73 & 28 & 91 & 10 & 23.03 & 200 & 5 & 6800 & 81.68 & 2.036 \\
\hline WASSON & 33 & 107 & 4 & 66.51 & 0.67 & 10 & 275 & 10 & 28.41 & 200 & 5 & 4900 & 55.35 & 1.993 \\
\hline HOWARD-GLASSCOCK PERM. & 32 & 86 & 25 & 58.2 & 0.2 & 12 & 147 & 10 & 15.94 & 200 & 5 & 1500 & 56.91 & 1.990 \\
\hline SUGARLAND UPPER FRIO & 29 & 149 & 900 & 59.86 & 0.33 & 29 & 85 & 10 & 22.91 & 200 & 5 & 3800 & 58.45 & 1.930 \\
\hline OYSTER BAYOU SEABREEZE & 36 & 190 & 1325 & 66.51 & 0.89 & 29 & 150 & 10 & 44.93 & 200 & 5 & 8300 & 75.20 & 1.920 \\
\hline LIVINGSTON WILCOX & 35 & 183 & 70 & 62.35 & 0.65 & 21 & 81 & 10 & 16.47 & 200 & 5 & 7400 & 78.44 & 1.787 \\
\hline SEMINOLE WEST & 34 & 102 & 9 & 68.17 & 0.82 & 10 & 180 & 10 & 19.06 & 200 & 5 & 5100 & 59.28 & 1.774 \\
\hline LAKE PASTURE H-440 S & 24 & 155 & 1197 & 56.53 & 0.32 & 32 & 75 & 10 & 21.07 & 200 & 5 & 4500 & 45.29 & 1.696 \\
\hline COWDEN NORTH & 35 & 114 & 7 & 63.27 & 0.68 & 10 & 125 & 10 & 12.28 & 200 & 5 & 4300 & 71.33 & 1.675 \\
\hline WELLMAN & 43 & 151 & 100 & 64.02 & 1.88 & 8 & 338 & 10 & 26.88 & 200 & 5 & 9300 & 73.34 & 1.633 \\
\hline WALNUT BEND REGULAR & 36 & 115 & 176 & 62.35 & 0.94 & 19 & 50 & 10 & 9.2 & 200 & 5 & 4900 & 83.53 & 1.591 \\
\hline GOOD & 44 & 140 & 52 & 53.21 & 1.94 & 8 & 246 & 10 & 16.26 & 200 & 5 & 8000 & 64.17 & 1.588 \\
\hline WADDELL & 34 & 88 & 12 & 53.21 & 0.78 & 11 & 100 & 10 & 9.09 & 200 & 5 & 3500 & 65.57 & 1.499 \\
\hline UNIV. BLOCK 31 DEVONIAN & 40 & 140 & 0.7 & 49.88 & 1.69 & 15 & 130 & 10 & 15.11 & 200 & 5 & 8500 & 75.70 & 1.484 \\
\hline SEMINOLE & 35 & 108 & 25 & 73.33 & 0.81 & 13 & 87 & 10 & 12.88 & 200 & 5 & 5200 & 55.25 & 1.458 \\
\hline HAWKINS WOODBINE & 24 & 168 & 3394 & 74.82 & 0.25 & 26 & 109 & 10 & 32.93 & 200 & 5 & 4500 & 21.30 & 1.449 \\
\hline TODD DEEP CRINOIDAL & 41 & 163 & 14 & 67.34 & 1.01 & 12 & 115 & 10 & 14.43 & 200 & 5 & 5800 & 73.71 & 1.417 \\
\hline TODD DEEP ELL. & 42 & 158 & 5 & 54.87 & 1.09 & 7 & 155 & 10 & 9.25 & 200 & 5 & 6000 & 76.58 & 1.390 \\
\hline WASSON 6600 AND 7200 & 33 & 118 & 10 & 63.18 & 0.71 & 8 & 135 & 10 & 10.6 & 200 & 5 & 6900 & 66.87 & 1.322 \\
\hline GOLDSMITII CLEAR FORK & 40 & 110 & 5 & 62.35 & 1.37 & 12 & 70 & 10 & 8.13 & 200 & 5 & 6100 & 84.35 & 1.304 \\
\hline GOLDSMITH 5600 & 38 & 105 & 25 & 58.2 & 1.14 & 15 & 50 & 10 & 6.78 & 200 & 5 & 5600 & 87.58 & 1.262 \\
\hline ANAHUAC MAIN FRIO & 35 & 178 & 1085 & 54.04 & 0.76 & 28 & 66 & 10 & 15.51 & 200 & 5 & 7100 & 78.03 & 1.241 \\
\hline YATES PEIRM. GUAD. & 30 & 82 & 118 & 62.35 & 0.29 & 10 & 120 & 10 & 11.62 & 200 & 5 & 1250 & 50.13 & 1.228 \\
\hline WARD-ESTES NORTH & 38 & 81 & 40 & 54.04 & 0.91 & 20 & 30 & 10 & 5.04 & 200 & 5 & 2500 & 72.68 & 1.198 \\
\hline TOM O'CONNOR 5900 & 35 & 176 & 2136 & 71.5 & 0.63 & 32 & 30 & 10 & 10.66 & 200 & 5 & 5900 & 58.55 & 1.178 \\
\hline GARZA & 35 & 90 & 8 & 43.23 & 0.49 & 21 & 55 & 10 & 7.75 & 200 & 5 & 2500 & 47.02 & 1.139 \\
\hline VEALMOOR EAST & 48 & 155 & 38 & 69.84 & 2.2 & 10 & 107 & 10 & 11.6 & 200 & 5 & 7400 & 49.80 & 1.138 \\
\hline EMPEROR DEEP & 33 & 80 & 20 & 48.22 & 0.67 & 17 & 61 & 10 & 7.77 & 200 & 5 & 2900 & 51.17 & 1.120 \\
\hline GILLOCK, S. BIG GAS & 38 & 154.8 & 900 & 64.02 & 1.41 & 28 & 36 & 10 & 10.02 & 200 & 5 & 9600 & 93.41 & 1.118 \\
\hline FALLS CITY LBAR., LPA. & 39 & $190^{\circ}$ & 371 & 62.35 & 0.73 & 30 & 25 & 10 & 7.26 & 200 & 5 & 6100 & 76.38 & 1.116 \\
\hline HELEN GOHLKE WILCOX & 34 & 240 & 180 & 58.2 & 0.59 & 20 & 47 & 10 & 8.5 & 200 & 5 & 8100 & 69.74 & 1.109 \\
\hline PLYMOUTH HEEP & 31 & 162 & 3300 & 66.51 & 0.52 & 28 & 28 & 10 & 8.1 & 200 & 5 & 5600 & 55.76 & 1.107 \\
\hline
\end{tabular}


Table 4.5.1. Ranking of Reservoirs With Positive Net Revenue (Continued)

\begin{tabular}{|c|c|c|c|c|c|c|c|c|c|c|c|c|c|c|}
\hline FIELD & DEG. API & TEMP, $\mathrm{F}$ & PERM. & So,\% & P/NIMP & POR.,\% & PAY & DIP & EOOIP & AREA & WELLS & DEPTH & TECH & ECON \\
\hline MIDLAND FARMS & 32 & 102 & 61 & 66.51 & 0.72 & 14 & 100 & 10 & 14.46 & 200 & 5 & 4800 & 56.80 & 1.093 \\
\hline GLASCO DEVONIAN & 37 & 186 & 200 & 58.2 & 1.39 & 14 & 67 & 10 & 8.48 & 200 & 5 & 12600 & 95.70 & 1.091 \\
\hline WEST RANCH 41-A & 32 & 171 & 869 & 59.86 & 0.55 & 30 & 35 & 10 & 9.76 & 200 & 5 & 5700 & 70.21 & 1.081 \\
\hline FUHRMAN-MASCHO & 32 & 95 & 5 & 54.04 & 0.71 & 13 & 72 & 10 & 7.86 & 200 & 5 & 4300 & 59.70 & 1.078 \\
\hline WHITE POINT E. BRIGHTON & 39 & 162 & 575 & 51.55 & 0.83 & 33 & 26 & 10 & 6.87 & 200 & 5 & 5700 & 73.64 & 1.074 \\
\hline SLICK WILCOX & 36 & 218 & 350 & 62.35 & 0.68 & 22 & 50 & 10 & 10.65 & 200 & 5 & 7300 & 76.46 & 1.044 \\
\hline WALNUT BEND HUDSPETH & 40 & 110 & 138 & 50.71 & 0.99 & 20 & 40 & 10 & 6.3 & 200 & 5 & 3900 & 67.97 & 1.042 \\
\hline CONROE MAIN CONROE & 38 & 170 & 1400 & 64.02 & 0.64 & 32 & 65 & 10 & 20.68 & 200 & 5 & 5200 & 79.68 & 1.037 \\
\hline WELCH & 33 & 96 & 9 & 63.18 & 0.86 & 10 & 100 & 10 & 9.81 & 200 & 5 & 4900 & 69.92 & 1.036 \\
\hline EMBAR ELLENBURGER & 45 & 115 & 40 & 62.35 & 2.32 & 5 & 195 & 10 & 9.44 & 200 & 5 & 7700 & 62.44 & 1.023 \\
\hline TOM O'CONNOR 5500 & 31 & 169 & 816 & 58.2 & 0.51 & 31 & 26 & 10 & 7.28 & 200 & 5 & 5500 & 63.98 & 1.007 \\
\hline VEALMOOR & 46 & 164 & 32 & $57.37^{\circ}$ & 1.83 & 10 & 95 & 10 & 8.46 & 200 & 5 & 7800 & 69.94 & 0.991 \\
\hline HAMLIN EAST & 39 & 117 & 350 & 64.85 & 0.65 & 19 & 25 & 10 & 4.78 & 200 & 5 & 3200 & 67.70 & 0.987 \\
\hline EAST TEXAS WOODBINE & 38 & 146 & 1300 & 71.5 & 0.56 & 25 & 35 & 10 & 9.72 & 200 & 5 & 3600 & 60.38 & 0.974 \\
\hline THIOMPSON FRIO & 25 & 168 & 1100 & 58.2 & 0.37 & 30 & 40 & 10 & 10.85 & 200 & 5 & 5400 & 47.80 & 0.966 \\
\hline SALT CREEK & 40 & 129 & 10 & 59.03 & 1.31 & 12 & 100 & 10 & 11 & 200 & 5 & 6300 & 87.97 & 0.942 \\
\hline SAND HILLS MCKNIGHT & 33 & 86 & 1 & 49.88 & 0.73 & 9 & 150 & 10 & 10.46 & 200 & 5 & 3500 & 52.91 & 0.928 \\
\hline CIIOCOLATE BAYOU ALIBEL & 42 & 225 & 400 & 58.2 & 1.27 & 29 & 26 & 10 & 6.81 & 200 & 5 & 9400 & 75.05 & 0.913 \\
\hline HALLEY & 34 & 83 & 20 & 58.2 & 0.67 & 16 & 45 & 10 & 6.51 & 200 & 5 & 2700 & 70.33 & 0.904 \\
\hline CORDONA LAKE DEV. & 40 & 103 & 15 & 49.88 & 1.49 & 18 & 60 & 10 & 8.37 & 200 & 5 & 5400 & 71.45 & 0.889 \\
\hline ADAIR WOLFCAMP & 43 & 133 & 28 & 63.18 & 1.84 & 12 & 68 & 10 & 8.01 & 200 & 5 & 8500 & 76.25 & 0.883 \\
\hline TAYLOR+LINK & 32 & 84 & 40 & 66.51 & 0.26 & 15 & 35 & 10 & 5.42 & 200 & 5 & 1300 & 49.73 & 0.877 \\
\hline SCARBOROUGH & 37 & 85 & 12 & 49.88 & 1.07 & 17 & 55 & 10 & 7.24 & 200 & 5 & 3000 & 72.56 & 0.863 \\
\hline AMACKER-TIPPETT ELL. & 53 & 201 & 23 & 70.67 & 4.28 & 6 & 285 & 10 & 18.77 & 200 & 5 & 12100 & 33.68 & 0.853 \\
\hline THOMPSON, S. 5400 & 25 & 155 & 900 & 59.03 & 0.42 & 31 & 29 & 10 & 8.24 & 200 & 5 & 5300 & 46.89 & 0.842 \\
\hline DARS'T CREEK EDIVARDS & 36 & 98.8 & 200 & 49.88 & 0.56 & 21 & 150 & 10 & 24.4 & 200 & 5 & 2600 & 57.93 & 0.841 \\
\hline HARDIN FRAZIER & 38 & 141.2 & 500 & 62.35 & 1.21 & 24 & 26 & 10 & 6.04 & 200 & 5 & 7900 & 91.90 & 0.831 \\
\hline REINECKE & 46 & 139 & 22 & 65.68 & 1.97 & 10 & 65 & 10 & 6.63 & 200 & 5 & 6800 & 62.39 & 0.827 \\
\hline HULL-SILK-SIKES 3800 & 39 & 108.4 & 180 & 62.35 & 0.83 & 17 & 26 & 10 & 4.28 & 200 & 5 & 3800 & 74.33 & 0.822 \\
\hline GATEWOOD & 33 & 90.8 & 148 & 62.35 & 0.3 & 23 & 20 & 10 & 4.45 & 200 & 5 & 1600 & 58.88 & 0.814 \\
\hline SANDUSKY OIL CREEK & 42 & 142 & 238 & 61.52 & 1.11 & 17 & 33 & 10 & 5.36 & 200 & 5 & 7200 & 80.78 & 0.814 \\
\hline DURKEE FAIRBANKS & 35 & 191 & 2400 & 63.18 & 0.68 & 34 & 25 & 10 & 8.34 & 200 & 5 & 7100 & 72.99 & 0.806 \\
\hline FIG RIDGE SEABREEZE & 35 & 198 & 750 & 52.38 & 0.81 & 27 & 34 & 10 & 7.47 & 200 & 5 & 8500 & 71.02 & 0.805 \\
\hline SHAFIER LAKE DEV. & 38 & 135 & 6 & 64.02 & 1.53 & 5 & 140 & 10 & 6.96 & 200 & 5 & 9500 & 88.55 & 0.797 \\
\hline MANVELI, I.1B. II OI.IG. & 28 & 165 & 500 & 68.17 & 0.46 & 28 & 48 & 10 & 14.23 & 200 & 5 & 5700 & 45.10 & 0.785 \\
\hline OLD OCEAN CHENAULT & 36 & 232 & 640 & 63.18 & 0.61 & 27 & 60 & 10 & 15.9 & 200 & 5 & 9600 & 72.90 & 0.782 \\
\hline
\end{tabular}


Table 4.5.1. Ranking of Reservoirs With Positive Net Revenue (Continued)

\begin{tabular}{|c|c|c|c|c|c|c|c|c|c|c|c|c|c|c|}
\hline FIELD & DEG. API & TEMP, F & PERMI. & So,\% & P/MINIP & POR., \% & PAY & DIP & EOOIP & AREA & WELLS & DEPTH & TECH & ECON \\
\hline THOMPSON, S. 4400 & 25 & 135 & 367 & 60.69 & 0.38 & 34 & 35 & 10 & 11.22 & 200 & 5 & 4400 & 44.88 & 0.778 \\
\hline UNION & 33 & 110 & 2 & 70.67 & 0.98 & 11 & 55 & 10 & 6.64 & 200 & 5 & 6900 & 59.91 & 0.775 \\
\hline HARPER & 36 & 92 & 2 & 54.04 & 0.79 & 10 & 50 & 10 & 4.2 & 200 & 5 & 4100 & 72.19 & 0.768 \\
\hline COWDEN S. 8790 CANYON & 40 & 147 & 4 & 60.69 & 1.53 & 8 & 65 & 10 & 4.9 & 200 & 5 & 8800 & 92.41 & 0.767 \\
\hline MANVEL F.B. I OLIG. & 28 & 165 & 500 & 68.17 & 0.42 & 28 & 48 & 10 & 14.23 & 200 & 5 & 5100 & 44.75 & 0.754 \\
\hline BRANTLEY JACKSON SMACK. & 40 & 205 & 25 & 73.99 & 1.18 & 22 & 50 & 10 & 12.64 & 200 & 5 & 9200 & 63.20 & 0.748 \\
\hline TXL ELLENBURGER & 44 & 138 & 39 & 70.67 & 2.2 & 4 & 240 & 10 & 10.54 & 200 & 5 & 9600 & 53.25 & 0.746 \\
\hline H-J STRAIVN & 42 & 122 & 100 & 59.86 & 1.22 & 9 & 50 & 10 & 4.18 & 200 & 5 & 5500 & 80.16 & 0.741 \\
\hline GANADO WEST 4700 & 24 & 146 & 1411 & 51.55 & 0.37 & 33 & 44 & 10 & 11.62 & 200 & 5 & 4700 & 35.79 & 0.735 \\
\hline CROSSETT DEV. & 44 & 106 & 6 & 54.04 & 1.8 & 22 & 88 & 10 & 16.25 & 200 & 5 & 5400 & 64.14 & 0.730 \\
\hline GOLDSMITH & 36 & 95 & 12 & 68.17 & 0.83 & 11 & 48 & 10 & 5.59 & 200 & 5 & 4100 & 66.72 & 0.728 \\
\hline PORTILLA 7400 & 40 & 206 & 1634 & 60.69 & 0.9 & 28 & 28 & 10 & 7.39 & 200 & 5 & 7400 & 76.23 & 0.726 \\
\hline HENDRICK & 28 & 83 & 7 & 49.88 & 0.52 & 8 & 100 & 10 & 6.2 & 200 & 5 & 2500 & 33.21 & 0.715 \\
\hline RILEY N. U. CLFK. & 32 & 107 & 12 & 55.7 & 0.99 & 8 & 70 & 10 & 4.84 & 200 & 5 & 6300 & 70.84 & 0.695 \\
\hline GOVT. WELLS, NORTH G.W. & 21 & 114 & 800 & 58.2 & 0.17 & 32 & 20 & 10 & 5.78 & 200 & 5 & 2200 & 33.15 & 0.677 \\
\hline VON ROEDER AND N.V.R & 43 & 134 & 13 & 66.51 & 1.57 & 10 & 45 & 10 & 4.65 & 200 & 5 & 6800 & 69.96 & 0.677 \\
\hline DOLLARHIDE CLEAR FORK & 38 & 120 & 10 & 62.35 & 1.35 & 15 & 40 & 10 & 5.81 & 200 & 5 & 6500 & 89.41 & 0.676 \\
\hline TALCO PALUXY & 22 & 147 & 2000 & 73.99 & 0.3 & 26 & 44 & 10 & 13.14 & 200 & 5 & 4300 & 20.78 & 0.675 \\
\hline SEELIGSON ZONE 19.C-4 & 43 & 125.2 & 585 & 64.02 & 1.56 & 24 & 25 & 10 & 5.97 & 200 & 5 & 5900 & 70.97 & 0.671 \\
\hline FAIRWAY JAMES LIME & 48 & 260 & 18 & 60.69 & 1.97 & 11 & 70 & 10 & 7.26 & 200 & 5 & 10000 & 57.56 & 0.658 \\
\hline SIVELLS BEND & 42 & 127 & 126 & 49.05 & 1.54 & 18 & 46 & 10 & 6.31 & 200 & 5 & 6600 & 66.26 & 0.657 \\
\hline SHARON RIDGE 2400 & 32 & 96 & 8 & 54.04 & 0.14 & 15 & 95 & 10 & 11.96 & 200 & 5 & 2400 & 53.78 & 0.652 \\
\hline LEVELLAND & 30 & 105 & 2 & 61.52 & 0.54 & 11 & 50 & 10 & 5.26 & 200 & 5 & 4900 & 55.22 & 0.643 \\
\hline WORTHAM WOODBINE & 39 & 101.2 & 1620 & 83.14 & 0.76 & 22 & 24 & 10 & 6.82 & 200 & 5 & 2900 & 44.26 & 0.642 \\
\hline GERALDINE-FORD & 41 & 100 & 49 & 45.73 & 0.89 & 22 & 28 & 10 & 4.37 & 200 & 5 & 2600 & 49.64 & 0.626 \\
\hline KEYSTONE SIL. & 39 & 120 & 3 & 74.82 & 1.52 & 6 & 113 & 10 & 7.88 & 200 & 5 & 8400 & 64.29 & 0.623 \\
\hline LIVINGSTON YEGUA & 40 & 154 & 120 & 83.14 & 0.69 & 28 & 15 & 10 & 5.42 & 200 & 5 & 4500 & 47.40 & 0.622 \\
\hline BIG MINERAL CRK. BARNES & 37 & 118 & 59 & 56.53 & 1.01 & 18 & 54 & 10 & 8.53 & 200 & 5 & 5300 & 85.19 & 0.622 \\
\hline COKE PALUXY & 27 & 190 & 1175 & 59.86 & 0.4 & 22 & 50 & 10 & 10.23 & 200 & 5 & 6300 & 50.21 & 0.613 \\
\hline FORT STOCKTON & 32 & 83 & 35 & 46.56 & 0.64 & 17 & 38 & 10 & 4.67 & 200 & 5 & 2800 & 43.15 & 0.600 \\
\hline GOLDSMITH DEVONIAN & 40 & 135 & 47 & 62.35 & 1.37 & 15 & 45 & 10 & 6.54 & 200 & 5 & 8000 & 88.82 & 0.577 \\
\hline SALT FLAT AUSTIN CHALK & 36 & 97.2 & 0.1 & 49.88 & 0.48 & 18 & 120 & 10 & 16.73 & 200 & 5 & 2400 & 57.23 & 0.571 \\
\hline LAWSON & 37 & 94 & 6 & 57.45 & 0.9 & 10 & 36 & 10 & 3.21 & 200 & 5 & 4300 & 78.94 & 0.566 \\
\hline EDWARDS WEST CANYON & 41 & 140 & 5 & 62.35 & 1.72 & 10 & 80 & 10 & 7.75 & 200 & 5 & 8700 & 86.33 & 0.562 \\
\hline FOSTER & 35 & 95 & 7 & 62.35 & 0.8 & 10 & 110 & 10 & 10.65 & 200 & 5 & 4300 & $7 \dot{4.36}$ & 0.560 \\
\hline BRECKENRIDGE POOL & 38 & 110 & 15 & 60.69 & 0.71 & 13 & 35 & 10 & 4.29 & 200 & 5 & 3100 & 75.32 & 0.557 \\
\hline
\end{tabular}


Table 4.5.1. Ranking of Reservoirs With Positive Net Revenue (Continued)

\begin{tabular}{|c|c|c|c|c|c|c|c|c|c|c|c|c|c|c|}
\hline FIELD & DEG. API & TEMP, F & PERM. & So, $\%$ & P/MMP & POR., \% & PAY & DIP & EOOIP & AREA & WELLS & DEPTH & TECH & ECON \\
\hline TOMBALL SCHULTZ SE & 40 & 182 & 1200 & 62.35 & 0.77 & 32 & 11 & 10 & 3.41 & 200 & 5 & 5500 & 74.29 & 0.554 \\
\hline SULPHUR BLUFF PALUXY & 21 & 114 & 4000 & 49.88 & 0.38 & 25 & 60 & 10 & 11.62 & 200 & 5 & 4500 & 24.08 & 0.550 \\
\hline GILLOCK BIG GAS & 38 & 214 & 1470 & 70.67 & 1 & 28 & 25 & 10 & 7.68 & 200 & 5 & 8400 & 64.33 & 0.548 \\
\hline UNIV. BLOCK 9 WOLFCAMP & 38 & 140 & 14 & 60.69 & 1.26 & 10 & 40 & 10 & 3.77 & 200 & 5 & 8400 & 94.56 & 0.546 \\
\hline EMMA ELLENBURGER & 49 & 185 & 54 & 66.51 & 3.16 & 3 & 290 & 10 & 8.99 & 200 & 5 & 12300 & 48.89 & 0.545 \\
\hline HULLDALE PENN. REEF & 40 & 156 & 43 & 59.86 & 0.82 & 9 & 39 & 10 & 3.26 & 200 & 5 & 5800 & 82.42 & 0.534 \\
\hline TOM O'CONNOR 4500 GRETA & 24 & 162 & 2290 & 56.53 & 0.29 & 33 & 20 & 10 & 5.79 & 200 & 5 & 4500 & 40.74 & 0.524 \\
\hline KELSEY M-2 & 47 & 160 & 454 & 60.69 & 1.31 & 25 & 16 & 10 & 3.77 & 200 & 5 & 4700 & 65.87 & 0.511 \\
\hline RINCON VICKSBURG SAND & 44 & 140 & 284 & 64.02 & 1.36 & 22 & 50 & 10 & 10.94 & 200 & 5 & 5300 & 73.95 & 0.509 \\
\hline SUSAN PEAK & 37 & 139 & 40 & 66.51 & 0.66 & 10 & 43 & 10 & 4.44 & 200 & 5 & 4700 & 72.88 & 0.508 \\
\hline FLUVANNA STRAWN & 40 & 140 & 93 & 60.69 & 1.27 & 10 & 42 & 10 & 3.96 & 200 & 5 & 7800 & 90.70 & 0.507 \\
\hline COWDEN NORTH DEEP & 37 & 107 & 7 & 60.51 & 0.98 & 8 & 40 & 10 & 3.31 & 200 & 5 & 5100 & 75.26 & 0.506 \\
\hline REEVES & 32 & 113 & 3 & 53.21 & 0.65 & 12 & 45 & 10 & 4.46 & 200 & 5 & 5600 & 58.35 & 0.503 \\
\hline SNYDER & 30 & 97 & 1 & 62.35 & 0.37 & 10 & 50 & 10 & 4.84 & 200 & 5 & 2600 & 52.30 & 0.492 \\
\hline RACCOON BEND COCKFIELD & 34 & 155 & 840 & 68.17 & 0.47 & 33 & 40.9 & 10 & 14.29 & 200 & 5 & 4200 & 64.88 & 0.486 \\
\hline HARRIS & 31 & 112 & 11 & 59.86 & 0.75 & 9 & 55 & 10 & 4.6 & 200 & 5 & 5900 & 64.23 & 0.482 \\
\hline SEELIGSON ZONE 19-B & 41 & 179 & 546 & 60.69 & 0.94 & 24 & 16 & 10 & 3.62 & 200 & 5 & 6100 & 78.47 & 0.472 \\
\hline LA ROSA 5900 & 30 & 125.2 & 1682 & 83.14 & 0.72 & 29 & 24 & 10 & 8.99 & 200 & 5 & 5900 & 30.14 & 0.470 \\
\hline UNIV. BLOCK 9 PENN. & 40 & 151 & 11 & 58.2 & 1.46 & 12 & 35 & 10 & 3.8 & 200 & 5 & 9000 & 90.81 & 0.465 \\
\hline SLAUGHTER & 30 & 108 & 11 & 66.51 & 0.53 & 12 & 48 & 10 & 5.95 & 200 & 5 & 5000 & 47.18 & 0.462 \\
\hline HENDERSON & 31 & 85 & 50 & 49.88 & 0.58 & 14 & 40 & 10 & 4.34 & 200 & 5 & 3100 & 44.58 & 0.454 \\
\hline FARGO 3900 & 41 & 109.2 & 100 & 58.2 & 0.97 & 17 & 22 & 10 & 3.38 & 200 & 5 & 3900 & 72.22 & 0.451 \\
\hline PAYTON & 36 & 81 & 35 & 66.51 & $0.7 !$ & 20 & 20 & 10 & 4.13 & 200 & 5 & 2000 & 62.96 & 0.448 \\
\hline GILLOCK EAST SEGMENT & 39 & 224 & 1330 & 35.75 & 0.87 & 29 & 42.5 & 10 & 6.84 & 200 & 5 & 9600 & 51.11 & 0.448 \\
\hline MERCHANT EY-IB & 30 & 205 & 230 & 65.68 & 0.6 & 31 & 28 & 10 & 8.85 & 200 & 5 & 8900 & 49.48 & 0.144 \\
\hline SHAMBURGER LAKE PALUXY & 32 & 206 & 200 & 70.67 & 0.54 & 21 & 28 & 10 & 6.45 & 200 & 5 & 7300 & 44.88 & 0.435 \\
\hline LOMA NOVIA LOMA NOVIA & 26 & 114 & 800 & 62.35 & 0.24 & 26 & 16 & 10 & 4.03 & 200 & 5 & 2600 & 37.92 & 0.433 \\
\hline SHAFTER LAKE SAN AND. & 34 & 105 & 5 & 62.35 & 0.73 & 8 & 37 & 10 & 2.87 & 200 & 5 & 4400 & 70.57 & 0.428 \\
\hline KINGDOM $\triangle B O$ & 30 & 121 & 5 & 64.02 & 0.83 & 7 & 70 & 10 & 4.87 & 200 & 5 & 7800 & 60.14 & 0.419 \\
\hline WEBSTER UPPER FRIO & 29 & 163 & 2350 & 62.35 & 0.52 & 31 & 150 & 10 & 45.03 & 200 & 5 & 5800 & 56.31 & 0.416 \\
\hline KERMIT & 34 & 83 & 14 & 54.04 & 0.73 & 15 & 22 & 10 & 2.77 & 200 & 5 & 2800 & 62.63 & 0.403 \\
\hline LUTHER S.E. SIL.-DEV. & 44 & 168 & 16 & 66.51 & 1.86 & 15 & 65 & 10 & 10.07 & 200 & 5 & 9900 & 69.62 & 0.382 \\
\hline ARANSAS PASS & 42 & 198 & 225 & 57.37 & 1.12 & 28 & 20 & 10 & 4.99 & 200 & 5 & 7100 & 74.73 & 0.374 \\
\hline LOVELL'S LAKE FRIO I & 38 & 167 & 450 & 49.88 & 1.04 & 29 & 45 & 10 & 10.11 & 200 & 5 & 7700 & 81.14 & 0.371 \\
\hline DOLLARHIDE SILURIAN & 42 & 120 & 9 & 64.85 & 1.94 & 6 & 194 & 10 & 11.72 & 200 & 5 & 8500 & 70.76 & 0.370 \\
\hline FLANAGAN U. CLFK. & 32 & 113 & 3 & 60.69 & 0.61 & 13 & 45 & 10 & 5.51 & 200 & 5 & 6300 & 64.84 & 0.355 \\
\hline
\end{tabular}


Table 4.5.1. Ranking of Reservoirs With Positive Net Revenue (Continued)

\begin{tabular}{|c|c|c|c|c|c|c|c|c|c|c|c|c|c|c|}
\hline FIELD & DEG. API & TEMP, F & PERM. & So,\% & P/MIMP & POR., \% & PAY & DIP & EOOIP & AREA & WELLS & DEPTH & TECH & ECON \\
\hline EMMA & 33 & 104 & 11 & 63.85 & 0.58 & 7 & 58 & 10 & 4.03 & 200 & 5 & 4000 & 63.77 & 0.354 \\
\hline KMA & 40 & 125 & 55 & 62.35 & 0.8 & 16 & 24 & 10 & 3.72 & 200 & 5 & 3700 & 72.54 & 0.350 \\
\hline WILLAMAR, W. W. WILLA. & 31 & 212 & 65 & 53.21 & 0.59 & 19 & 34 & 10 & 5.34 & 200 & 5 & 7900 & 52.04 & 0.345 \\
\hline RUSSELL 7000 CLFK. & 35 & 127 & 2 & 62.35 & 0.81 & 5 & 95 & 10 & 4.6 & 200 & 5 & 7000 & 78.96 & 0.335 \\
\hline TAFT 4000 & 23 & 133 & 1500 & 64.02 & 0.32 & 25 & 30 & 10 & 7.46 & 200 & 5 & 4000 & 36.24 & 0.326 \\
\hline TEX-HAMON FUSSELMAN & 40 & 154 & 25 & 54.04 & 1.86 & 7 & 65 & 10 & 3.82 & 200 & 5 & 11600 & 87.54 & 0.325 \\
\hline UNIV. BLOCK 9 DEV. & 45 & 176 & 3 & 69 & 2.03 & 5 & 107 & 10 & 5.73 & 200 & 5 & 10500 & 58.36 & 0.315 \\
\hline HAYNES MITCHELL & 40 & 148 & 25 & 56.53 & 1.04 & 17 & 18 & 10 & 2.69 & 200 & 5 & 5900 & 82.49 & 0.313 \\
\hline LEA ELLENBURGER & 43 & 138 & 300 & 78.15 & 1.88 & 2 & 202 & 10 & 4.9 & 200 & 5 & 8200 & 49.90 & 0.311 \\
\hline TUNSTILL & 40 & 88 & 30 & 51.55 & 1.16 & 25 & 12 & 10 & 2.4 & 200 & 5 & 3300 & 67.97 & 0.310 \\
\hline HOBO & 46 & 150 & 32 & 58.2 & 1.72 & 10 & 39 & 10 & 3.53 & 200 & 5 & 7100 & 69.67 & 0.292 \\
\hline TWOFREDS DELAWARE & 35 & 104 & 33 & 46.56 & 1 & 20 & 21 & 10 & 3.04 & 200 & 5 & 4900 & 59.57 & 0.286 \\
\hline WALNUT BEND WINGER & 32 & 143 & 309 & 69 & 0.69 & 17 & 21 & 10 & 3.83 & 200 & 5 & 5500 & 55.35 & 0.280 \\
\hline WILLAMAR WILLAMAR & 30 & 200 & 140 & 62.35 & 0.59 & 23 & 20 & 10 & 4.45 & 200 & 5 & 7600 & 54.10 & 0.279 \\
\hline CAYUGA WOODBINE & 29 & 160 & 500 & 66.51 & 0.23 & 25 & 35 & 10 & 9.04 & 200 & 5 & 4000 & 49.16 & 0.278 \\
\hline KEYSTONE ELLENBURGER & 44 & 144 & 5 & 54.87 & 2.21 & 3 & 300 & 10 & 7.67 & 200 & 5 & 9600 & 67.51 & 0.272 \\
\hline HEYSER 5400 & 34 & 164 & 300 & 54.04 & 0.62 & 24 & 13 & 10 & 2.62 & 200 & 5 & 5400 & 70.06 & 0.264 \\
\hline MCELROY & 32 & 86 & 50 & 65.51 & 0.61 & 16 & 86 & 10 & 14 & 200 & 5 & 2900 & 56.48 & 0.261 \\
\hline HOWARD-GLASSCOCK GLOR. & 27 & 100 & 4 & 58.2 & 0.29 & 11 & 60 & 10 & 5.97 & 200 & 5 & 3200 & 43.33 & 0.257 \\
\hline GOLDSMITH NORTH & 35 & 95 & 2 & 59.86 & 0.79 & 8 & 35 & 10 & 2.6 & 200 & 5 & 4400 & 74.79 & 0.253 \\
\hline WEST RANCH 98-A & 40 & 178 & 497 & 58.2 & 0.88 & 30 & 32 & 10 & 8.68 & 200 & 5 & 6100 & 81.90 & 0.248 \\
\hline KEYSTONE HOLT & 40 & 92 & 58 & 59.03 & 1.39 & 18 & 55 & 10 & 9.08 & 200 & 5 & 4800 & 84.55 & 0.246 \\
\hline HITTS LAKE PALUXY & 26 & 175 & 400 & 74.82 & 0.49 & 22 & 32 & 10 & 8.18 & 200 & 5 & 7200 & 25.39 & 0.244 \\
\hline SHARON RIDGE 1700 & 28 & 90 & 3 & 52.38 & 0.26 & 15 & 35 & 10 & 4.27 & 200 & 5 & 1700 & 35.52 & 0.235 \\
\hline KELLY-SNYDER & 42 & 130 & 19 & 64.85 & 1.56 & 8 & 137 & 10 & 11.04 & 200 & 5 & 6700 & 74.57 & 0.227 \\
\hline TOM O'CONNOR 5800 & 36 & 176 & 1758 & 69.84 & 0.67 & 32 & 16 & 10 & 5.55 & 200 & 5 & 5800 & 62.39 & 0.226 \\
\hline NEVA WEST STRAWN & 46 & 158 & 8 & 59.86 & 1.38 & 10 & 80 & 10 & 7.44 & 200 & 5 & 6200 & 71.61 & 0.224 \\
\hline DOLLARHIDE ELL. & 41 & 139 & 5 & 55.7 & 1.88 & 3 & 187 & 10 & 4.85 & 200 & 5 & 10000 & 80.67 & 0.201 \\
\hline AMROW DEVONIAN & 35 & 178 & 34 & 58.2 & 1.29 & 4 & 131 & 10 & 4.74 & 200 & 5 & 12600 & 92.41 & 0.200 \\
\hline SEELIGSON ZONE 14-B & 40 & 164 & 353 & 54.04 & 0.86 & 26 & 11 & 10 & 2.4 & 200 & 5 & 5100 & 75.19 & 0.196 \\
\hline LOLITA WARD ZONE & 32 & 171 & 635 & 57.37 & 0.56 & 30 & 10 & 10 & 2.67 & 200 & 5 & 5900 & 66.20 & 0.194 \\
\hline ROUND TOP PALO PINTO & 40 & 140 & 6 & 62.35 & 0.82 & 10 & 90 & 10 & 8.72 & 200 & 5 & 4800 & 79.32 & 0.182 \\
\hline FARMER & 30 & 95.6 & 4 & 59.03 & 0.34 & 10 & 75 & 10 & 6.88 & 200 & 5 & 2200 & 52.99 & 0.175 \\
\hline DOLLARHIDE DEVONIAN & 40 & 120 & 17 & 59.86 & 1.58 & 14 & 70 & 10 & 9.11 & 200 & 5 & 8000 & 87.15 & 0.172 \\
\hline GIDDINGS AUSTIN CHALK & 40 & 225 & 0.1 & 36.58 & 0.94 & 6 & 150 & 10 & 5.11 & 200 & 5 & 7500 & 48.01 & 0.170 \\
\hline COGDELL & 42 & 136 & 18 & 54.04 & 1.49 & 10 & 73 & 10 & 6.13 & 200 & 5 & 6800 & 77.31 & 0.166 \\
\hline
\end{tabular}


Table 4.5.1. Ranking of Reservoirs With Positive Net Revenue (Continued)

\begin{tabular}{|c|c|c|c|c|c|c|c|c|c|c|c|c|c|c|}
\hline FIELD & DEG. API & TEMP, F & PERM. & So, $\%$ & P/NIMP & POR.,\% & PAY & DIP & EOOIP & AREA & WELLS & DEPTH & TECH & ECON \\
\hline DARST CREEK BUDA & 32 & 95.6 & 0.1 & 42.4 & 0.3 & 12 & 90 & 10 & 7.11 & 200 & 5 & 2200 & 35.46 & 0.165 \\
\hline VAUGHN & 28 & 90 & 10 & 51.63 & 0.21 & 14 & 30 & 10 & 3.37 & 200 & 5 & 1500 & 32.95 & 0.154 \\
\hline MABEE & 32 & 106 & 8 & 48.22 & 0.67 & 11 & 40 & 10 & 3.3 & 200 & 5 & 4700 & 47.78 & 0.118 \\
\hline GRETA 4400 & 24 & 145 & 687 & 60.69 & 0.34 & 33 & 25 & 10 & 7.78 & 200 & 5 & 4400 & 43.28 & 0.113 \\
\hline SOJOURNER & 41 & 120.4 & 15 & 58.2 & 1.13 & 14 & 19 & 10 & 2.4 & 200 & 5 & 5300 & 77.32 & 0.113 \\
\hline BEDFORD DEVONIAN & 41 & 138 & 5 & 54.04 & 1.62 & 11 & 100 & 10 & 9.23 & 200 & 5 & 8800 & 80.88 & 0.112 \\
\hline FLOUR BLUFF PHILLIPS & 44 & 186 & 745 & 49.88 & 1.2 & 31 & 25 & 10 & 6 & 200 & 5 & 6600 & 58.67 & 0.099 \\
\hline DIAMOND M & 44 & 130 & 72 & 59.86 & 1.81 & 9 & 80 & 10 & 6.69 & 200 & 5 & 6600 & 73.91 & 0.097 \\
\hline COTTONWOOD CR. SOUTH & 36 & 220 & 790 & 46.56 & 0.68 & 22 & 22 & 10 & 3.5 & 200 & 5 & 7600 & 53.73 & 0.087 \\
\hline DUNE & 34 & 88 & 6 & 61.11 & 0.72 & 10 & 80 & 10 & 7.59 & 200 & 5 & 3300 & 71.63 & 0.085 \\
\hline ELIASVILLE POOL & 39 & 115 & 8 & 62.35 & 0.59 & 12 & 27 & 10 & 3.14 & 200 & 5 & 3300 & 69.23 & 0.083 \\
\hline KILDARE RODESSA & 40 & 158 & 27 & 66.51 & 0.86 & 16 & 17 & 10 & 2.81 & 200 & 5 & 6000 & 71.53 & 0.079 \\
\hline GARCIA GARCIA MAIN & 47 & 152 & 1285 & 68.17 & 1.04 & 32 & 12 & 10 & 4.07 & 200 & 5 & 3800 & 48.18 & 0.079 \\
\hline NOLLEY WOLFCAMP & 37 & 130 & 20 & 59.86 & 1.51 & 9 & 60 & 10 & 5.02 & 200 & 5 & 9100 & 94.07 & 0.076 \\
\hline OCEANIC & 42 & 160 & 84 & 68.17 & 1.37 & 12 & 60 & 10 & 7.62 & 200 & 5 & 8100 & 74.15 & 0.075 \\
\hline HEADLEE ELLENBURGER & 51 & 208 & 40 & 66.51 & 3.71 & 2 & 325 & 10 & 6.71 & 200 & 5 & 13300 & 42.67 & 0.071 \\
\hline BIG LAKE & 36 & 125 & 20 & 66.51 & 0.45 & 19 & 30 & 10 & 5.89 & 200 & 5 & 3000 & 64.17 & 0.069 \\
\hline SPRABERRY TREND & 39 & 132 & 0.3 & 54.04 & 1.02 & 10 & 25 & 10 & 2.1 & 200 & 5 & 6800 & 78.46 & 0.065 \\
\hline KATZ 5100 & 37 & 120 & 56 & 53.21 & 0.89 & 16 & 35 & 10 & 4.63 & 200 & 5 & 5100 & 75.02 & 0.055 \\
\hline ELKHORN ELLENBURGER & 39 & 179 & 34 & 83.14 & 0.93 & 2 & 121 & 10 & 3.12 & 200 & 5 & 7200 & 57.78 & 0.054 \\
\hline CHOCOLATE BAYOU U. FRIO & 42 & 212 & 1090 & 54.87 & 1.23 & 28 & 27 & 10 & 6.44 & 200 & 5 & 8800 & 71.74 & 0.049 \\
\hline FULLERTON SOUTH ELL. & 44 & 132 & 77 & 70.67 & 2.54 & 2 & 275 & 10 & 6.04 & 200 & 5 & 10700 & 51.77 & 0.048 \\
\hline HARPER ELLENBURGER & 46 & 163 & 2 & 58.2 & 2.4 & 2 & 225 & 10 & 4.07 & 200 & 5 & 12300 & 66.66 & 0.043 \\
\hline SAND HILLS TUBB & 35 & 96 & 30 & 49.88 & 0.96 & 12 & 47 & 10 & 4.37 & 200 & 5 & 4500 & 67.73 & 0.04 \\
\hline FARNSWORTH U. MORROW & 38 & 170 & 48 & 57.37 & 0.65 & 15 & 21 & 10 & 2.81 & 200 & 5 & 7900 & 78.05 & 0.04 \\
\hline FULLERTON 8500 DEV. & 45 & 120 & 50 & 62.35 & 2.49 & 8 & 40 & 10 & 3.1 & 200 & 5 & 8500 & 66.43 & 0.034 \\
\hline CROSSETT SOUTH DEV. & 42 & 107 & 3 & 49.88 & 1.55 & 19 & 80 & 10 & 11.78 & 200 & 5 & 5600 & 64.33 & 0.022 \\
\hline BOYD CONGL. & 40 & 136 & 55 & 54.04 & 1.09 & 14 & 27 & 10 & 3.17 & 200 & 5 & 6000 & 78.88 & 0.012 \\
\hline TOMBALL KOBS & 40 & 182 & 1000 & 57.37 & 0.77 & 31 & 6.5 & 10 & 1.8 & 200 & 5 & 5500 & 74.44 & 0.008 \\
\hline EL MAR DELAWARE & 41 & 114 & 14 & 45.73 & 1.16 & 22 & 15 & 10 & 2.34 & 200 & 5 & 4500 & 56.33 & 0.008 \\
\hline MAGNET-WITIIERS & 26 & 171 & 1700 & 60.69 & 0.4 & 29 & 67 & 10 & 18.31 & 200 & 5 & 5600 & 50.33 & 0.002 \\
\hline
\end{tabular}




\subsection{Conclusions}

Of the 431 reservoirs screened, 211 projected revenue that exceeded cost, i.e., were profitable. Only the top 154 reservoirs, however, showed a profit greater than 30 percent. The top ten reservoirs predicted a profit of at least 80 percent. Six of the top ten were Gulf Coast sandstones.

The reservoirs are representative of the most productive discoveries in Texas. They account for approximately 72 percent of the recorded 52 billion barrels of oil production in the State. The preliminary evaluation of the reservoirs performed in this study implied that potential production from $\mathrm{CO}_{2}-\mathrm{EOR}$ could be as much as 4 billion barrels.

In order to enhance the chances of achieving this increase in production, the Department of Energy should consider a concerted effort to follow up this analysis with a targeted outreach program to the specific independent operators controlling the leases applicable to these reservoirs/resources. Development of ownership/technical potential maps and an outreach program should be initiated to aid this identification. 


\section{Bibliography}

Alston, R. B., Kokolis, G. P., and James, C. F.: " $\mathrm{CO}_{2}$ Minimum Miscibility Pressure: A Correlation for Impure $\mathrm{CO}_{2}$ Streams and Live Oil," paper SPE 11959 presented at the 1983 SPE Annual Technical Conference and Exhibition, San Francisco, Oct. 5-8.

Brinlee, L. D. and Brandt, J. A.: "Planning and Development of the Northeast Purdy Springer $\mathrm{CO}_{2}$ Miscible Project," paper SPE 11163 presented at the 1982 SPE Annual Technical Conference and Exhibition, New Orleans, Sep. 26-29.

Brock, W. R. and Bryan, L. A.: "Summary Results of $\mathrm{CO}_{2}$ EOR Field Tests, 1972-1987," paper SPE 18977 presented at the SPE Joint Rocky Mountain Regional/Low Permeability Reservoirs Symposium and Exhibition, Denver, March 6-8, 1989.

Brummert, A. C., et al.: "Rock Creek Oil Field $\mathrm{CO}_{2}$ Pilot Tests, Roane County, West Virginia," JPT (March 1988) 339-347.

Claridge, E. L., Jr., "Carbon Dioxide Flooding Strategy in a Communicating Layered Reservoir," SPEJ (April 1972) 143-154.

Cobb, L. B. : "Target Reservoirs Got $\mathrm{CO}_{2}$ Miscible Flooding - Task Two: Summary of Available Reservoir and Geologic Data", Vol. 1, Parts 1-4; U.S. Department of Energy, Report DOE/MC/08341-31, p. 1119 (1981).

Craig, F. F.: The Reservoir Engineering Aspects of Waterflooding, Monograph Series, SPE, Dallas, (1971).

Davis, D. W.: "Project Design of a $\mathrm{CO}_{2}$ Miscible Flood in a Waterflooded Sandstone Reservoir," paper SPE 27758 presented at the SPE/DOE Ninth Symposium on Improved Oil Recovery, Tulsa, April 17-20, 1994.

Diaz, Daniel Arturo: "Screening Criteria for Application of Carbon Dioxide Miscible Displacement in Waterflooded Reservoirs Containing Light Oil", M.S. Thesis, Louisiana State University, (1995).

Dobitz, J. K. and Prieditis, J.: "A Stream Tube Model for the PC," paper SPE 27750 presented at the SPE/DOE Ninth Symposium on Improved Oil, Tulsa, April 17-20, 1994.

Flanders, W. A., McGinnis, R. A., and Shatto, A. G.: " $\mathrm{CO}_{2}$ EOR Economics for Small to Medium Size Fields," paper SPE 26391 presented at the 1993 SPE Annual Technical Conference and Exhibition, Houston, Oct. 3-6. 
Flanders, W. A. and DePauw, R. M.: "Update Case History: Performance of the Twofreds Tertiary $\mathrm{CO}_{2}$ Project," paper SPE 26614 presented at the 1993 SPE Annual Technical Conference and Exhibition, Houston, Oct. 3-6.

Fox, M. J., Simlote, V.N., and Beaty, W. G.: "Evaluation of $\mathrm{CO}_{2}$ Flood Performance, Springer A Sand, NE Purdy Unity, Garvin County, OK," paper SPE 12665 presented at the SPE/DOE Fourth Symposium on Enhanced Oil Recovery, Tulsa, April 15-18, 1984.

Fox, M., et al.: "Review of $\mathrm{CO}_{2}$ Flood, Springer A Sand, Northeast Purdy Unit, Garvin County, Oklahoma," SPE Reservoir Engineering (Nov. 1988) 1161-1167.

Goodrich, J. H.: "Review and Analysis of Past and Ongoing Carbon Dioxide Injection Field Tests," paper SPE 8832 presented at the SPE/DOE Sixth Symposium on Improved Oil Recovery, Tulsa, April 20-23, 1980.

Grue, D. J. and Zana, E. T.: "Study of a Possible $\mathrm{CO}_{2}$ Flood in Rangely Weber," JPT (July 1981) 13121318.

Hadlow, R. E.: "Update of Industry Experience with $\mathrm{CO}_{2}$ Injection," paper SPE 24928 presented at the 1992 SPE Annual Technical Conference and Exhibition, Washington, D.C., Oct. 4-7.

Hallenbeck, L. D., et al.: "Innovative Approach to $\mathrm{CO}_{2}$ Project Development Holds Promise for Improving $\mathrm{CO}_{2}$ Flood Economics in Smaller Fields Near Abandonment," paper SPE 28334 presented at the 1994 SPE Annual Technical Conference and Exhibition, New Orleans, Sep. 25-28.

Hansen, P. W.: "A $\mathrm{CO}_{2}$ Tertiary Recovery Pilot: Little Creek Field, Mississippi," paper SPE 6747 presented at the 1977 SPE Annual Technical Conference and Exhibition, Denver, Oct. 9-12.

Haynes, H. J., et al.: Enhanced Oil Recovery, National Petroleum Council, Washington, D.C. (1976).

Hervey, J. R. and lakovakis, A. C.: "Performance Review of a Miscible $\mathrm{CO}_{2}$ Tertiary Project: Rangely Weber Sand Unit, Colorado," paper SPE 19653 presented at the 1989 SPE Annual Technical Conference and Exhibition, San Antonio, Oct. 8-11.

Hicks, J.M., and Foster, R.S.: "Evaluation of Target Oil and 50 Major Reservoirs in the Texas Gulf Coast for Enhanced Oil Recovery," U.S. Department of Energy Report DOE/EIA/0037-162P (1980).

Hoiland, R. C., Joyner, H. D., and Staldr, J. : "Case History of a Successful Rocky Mountain Pilot $\mathrm{CO}_{2}$ Flood," paper SPE 14939 presented at the SPE/DOE Fifth Symposium on Enhanced Oil Recovery, Tulsa, 20-23, 1986.

Holm, L. W. and Josendal, V. A.: "Study Shows Best Use of $\mathrm{CO}_{2}$ as EOR Agent," Oil \& Gas Journal (Oct. $22,1984)$ 131-134. 
Holm, L. W. and Josendal, V. A.: "Mechanisms of Oil Displacement by Carbon Dioxide," JPT (Dec. 1974) 1427-1436. .

Holm, L. W.: "Miscibility and Miscible Displacement," JPT (Aug. 1986) 817-818.

Holm, L.W., "Evolution of the Carbon Dioxide Process," JPT (Nov. 1987) 1337-1342.

Hsie, J. C. and Moore, J. S.: "The Quarantine Bay 4RC $\mathrm{CO}_{2}$ WAG Pilot Project: A Postflood Evaluation," SPE Reservoir Engineering (Aug. 1988) 809-814.

Kirkpatrick, R. K., Flanders, W. A., and DePauw, R. M.: "Performance of the Twofreds $\mathrm{CO}_{2}$ Injection Project." paper SPE 14439 presented at the 1985 SPE Annual Technical Conference and Exhibition, Las Vegas, Sep. 22-25.

Kleinstelber, S. W.: "The Wertz Tensleep $\mathrm{CO}_{2}$ Flood: Design and Initial Performance," JPT (May 1990) 630-636.

Klins, M. A.: Carbon Dioxide Flooding, IHRDC, Boston, 1984.

Koemer, R. H.: "Connections with Time," JPT (Jan. 1995) 5-6.

Koval, D. J.: "A Method for Predicting the Performance of Unstable Miscible Displacement in Heterogeneous Media," SPEJ (June 1963) 145-154.

Kumar, R. and Einbeck, J. N.: " $\mathrm{CO}_{2}$ Flooding a Waterflooded Shallow Pennsylvanian Sand in Oklahoma: A Case History," paper SPE 12668 presented at the SPE/DOE Fourth Symposium on Enhanced Oil Recovery, Tulsa, April 15-18, 1984.

Leach, M.P. and Yellig, W. F.: "Compositional Model Studies $-\mathrm{CO}_{2} / \mathrm{Oil}$-Displacement Mechanism," SPEJ (Aug. 1979) 89-97.

Lewin and Associates, Inc.: "The Potential and Economics of Enhanced Oil Recovery," prepared under U.S. FEA Contract No. C0-03-50222-000, Washington, D.C. (April 1976).

Martin, F. D. and Taber, J. J.: "Carbon Dioxide Flooding," JPT (April 1992) 396-400.

Martin, F. D.: "Enhanced Oil Recovery for Independent Producers," paper SPE 24142 presented the SPE/DOE Eighth Symposium on Enhanced Oil Recovery, Tulsa, April 22-24, 1992.

Metcalfe, R. S. and Yarborough, L.: "The Effect of Oil Phase Equilibria on the $\mathrm{CO}_{2}$ Displacement Mechanism," SPEJ (Feb. 1981) 89-97. 
Moritis, G.: "EOR Dips in U.S. But Remains a Significant Factor, Oil \& Gas Journal, (Sep. 26, 1994) 5179.

Mungan, N.: "An Evaluation of Carbon Dioxide Flooding," paper SPE 21761 presented at the SPE Western Regional Meeting, Long Beach, March 20-22, 1991.

Mungan, N.: "Enhanced Oil Recovery Using Water as a Driving Fluid. Part 7 - Field Applications of Carbon Dioxide Flooding," World Oil (Aug. 1981) 69-84.

Mungan, N.: "Enhanced Oil Recovery Using Water as a Driving Fluid. Part 6 - Fundamental Aspects of Carbon Dioxide Flooding," World Oil (Aug., 1981) 69-84.

Mungan, N.: "Enhanced Recovery Under Constrained Conditions," JPT (Aug. 1990) 962-964.

Orr, F. M., Jr. and Silva, M. K.: "Effect of Oil Composition on Minimum Miscibility Pressure -- Part 2: Correlation," SPERE (Nov. 1987) 479-491.

Paul, G. W., Lake, L. W., and Gould, T. L.: "A Simplified Model for $\mathrm{CO}_{2}$ Miscible Flooding," paper SPE 13238 presented at the 1984 SPE Annual Technology Conference and Exhibition, Houston, Sep. 5-8.

Philips, L. A., McPherson, J. L. and Leibrecht, R. J.: "CO 2 Flood: Design and Initial Operations, Ford Geraldine (Delaware Sand) Unit," paper SPE 12197 presented at the 1983 SPE Annual Technical Conference and Exhibition, San Francisco, Oct. 5-8.

Pittaway, K. R. and Rosato, R. J.: "The Ford Geraldine Unit $\mathrm{CO}_{2}$ Flood -- Update 1990," SPE Reservoir Engineering (Nov. 1991) 410-414.

Rickford, R. L. and Finney, T. P.: "Formation Damage From Fine Particulate Invasion: An Example from the Lost Soldier Tensleep Formation," SPEPE (Aug. 1991) 247.

Rivas, O., Embid, S., and Boliver, F." "Ranking Reservoirs for $\mathrm{CO}_{2}$ Flooding Processes," SPE paper 23641 presented at the 1992 SPE Latin American Petroleum Engineering Conference, Caracas, March 8-11.

Robl, F. W., Emanuel, A. S. and Van Meter, Jr., O. J.: "The 1984 National Petroleum Council Estimate of Potential EOR for Miscible Process," JPT (Aug. 1986) 875-882.

Sebastian, H. M., Wenger, R. S., and Renner, T. A.: "Correlation of Minimum Miscibility Pressure for Impure $\mathrm{CO}_{2}$ Streams," JPT (Nov. 1985) 2076-2082.

Simlote, V. N. and Withjack, E. M.: "Estimation of Tertiary Recovery by $\mathrm{CO}_{2}$ Injection -- Springer A Sand, Northeast Purdy Unit." JPT (May 1981) 808-818. 
Smith, D. L.: "Computer Graphical Analysis Method Proves Beneficial in Lost Soldier Field Deviated Well Application," JPT (June 1982) 1186.

Stalkup, F. I., Jr.: "Displacement of Oil by Solvent at High Water Saturation," SPEJ (Dec. 1970) 337-348.

Stalkup, F. I.: "Carbon Dioxide Miscible Flooding: Past, Present, and Outlook for the Future," JPT (Aug. 1978) 1102-1112.

Texas Railroad Commission: "A Survey of Secondary and Enhanced Recovery Operations in Texas to 1980," Austin TX, 554P.

Texas Railroad Commission: "1981 Annual Report," Austin TX.

Todd, M. R. and Longstaff, W. J.: "The Development, Testing and Application of a Numerical Simulator for Predicting Miscible Flood Performance," JPT (July 1972) 874-882, Trans., AIME, 253.

Trash, J. C.: "Twofreds Field: A Tertiary Oil Recovery Project," paper SPE 8382 presented at the 1979 SPE Annual Technical Conference and Exhibition, Dallas, Sep. 23-26.

Willhite, P. G.: Waterflooding, SPE Textbook Series Vol. 3, Society of Petroleum Engineers, Richardson (1986) 208.

Winzinger, R., et al.: "Design of a Major $\mathrm{CO}_{2}$ Flood, North Ward Estes Field, Ward County, Texas," SPE Reservoir Engineering (Aug. 1988) 809-814.

Yellig,W. F. and Metcalfe, R. S.: "Determination and Prediction of the $\mathrm{CO}_{2}$ Minimum Miscibility Pressures," JPT (Jan. 1980) 160-168.

Youngren, G. K. and Charlson, G. S.: "History Match of the Little Creek CO, Pilot Test," JPT (Nov. 1980) 2042-2052. 


\section{References}

1. Rivas, O., Embid S., and Bolivar, F., "Ranking Reservoirs for $\mathrm{CO}_{2}$ Flooding Processes," SPE Paper 23641 presented at the 1992 SPE Latin American Conference, Caracas, Venezuela, March 8-11.

2. Diaz, Daniel Arturo, "Screening Criteria for Application of Carbon Dioxide Miscible Displacement in Waterflooded Reservoirs Containing Light Oil," M.S. thesis, Louisiana State University, (1995).

3. Oil and Gas Journal, International Petroleum Encyclopedia, 1995, Vol. 28.

4. Diaz, Daniel Arturo, M.S. thesis, Louisiana State University, (1995).

5. Martin, F.D. and Taber, J.J., "Carbon Dioxide Flooding," Journal of Petroleum Technology (April 1992), pp. 396-400.

6. Anada, H., King, D., Seskus, A., and Fraser, M., "Feasibility and Economics of By-Product $\mathrm{CO}_{2}$ Supply for Enhanced Oil Recovery, Final SAIC Report to Morgantown Energy Technology Center, 1982.

7. Klins, M.A.: Carbon Dioxide Flooding, IHRDC, Boston, 1984.

8. Lewin and Associates, Inc.: "The Potential and Economics of Enhanced Oil Recovery," prepared under U.S. FEA Contract No. C0-03-50222-000, Washington, D.C. (April 1976).

9. Flanders, W. A., McGinnis, R. A., and Shatto, A. G.: " $\mathrm{CO}_{2}$ EOR Economics for Small to Medium Size Fields," paper SPE 26391 presented at the 1993 SPE Annual Technical Conference and Exhibition, Houston, Oct. 3-6.

10. Klins, M.A:: IHRDC, Boston, 1984.

11. Lewin and Associates, Inc.: Washington, D.C. (April 1976).

12. Martin, F. D.: "Enhanced Oil Recovery for Independent Producers," paper SPE 24142 presented at the SPE/DOE Eighth Symposium on Enhanced Oil Recovery, Tulsa, April 22-24, 1992.

13. Flanders, W. A.: 1993 SPE Annual Technical Conference and Exhibition, Houston, Oct. 3-6.

14. Haynes, H. J., et al.: Enhanced Oil Recovery, National Petroleum Council, Washington, D.C. (1976).

15. Martin, F. D.: Eighth Symposium on Enhanced Oil Recovery, Tulsa, April 22-24, 1992.

16. Robl, F. W., Emanuel, A. S. and Van Meter, Jr., O. J.: "The 1984 National Petroleum Council Estimate of Potential EOR for Miscible Process," JPT (Aug. 1986) 875-882. 
Appendix A

Texas Reservoir Database 
Table A1. Texas Reservoir Database

\begin{tabular}{|c|c|c|c|c|c|c|c|c|c|c|c|c|}
\hline $\begin{array}{l}\text { CNTY } \\
\text { CODE }\end{array}$ & FIELD_RES & $\begin{array}{l}\text { RRC } \\
\text { DIST }\end{array}$ & PROVINCE & $\begin{array}{l}\text { PRODUCING } \\
\text { FORMATION }\end{array}$ & LITH & DRIVE & DEPTH & $\begin{array}{l}\text { NET } \\
\text { PAY }\end{array}$ & $\begin{array}{c}\text { OIL } \\
\text { COLUMN }\end{array}$ & $\begin{array}{l}\text { AVG. } \\
\text { PERM }\end{array}$ & API & $\begin{array}{l}\text { CUMULATIVE } \\
\text { PRODUCTION }\end{array}$ \\
\hline 42163 & BIG FOOT OLMOS B & 1 & GULF COAST BASIN & OLMOS & SS & SG & 3300.0 & 13.0 & 580 & 3.00 & 43.00 & 31.33 \\
\hline 42127 & BIG WELLS SAN MIGUEL & 1 & GULF COAST BASIN & SAN MIGUEL & SS & SG+LGCE & 5400.0 & & 200 & 6.00 & 33.00 & 54.58 \\
\hline 42013 & CHARLOTIE NAVARRO & 1 & GULF COAST BASIN & NAVARRO & SS & SG+MGCE & 5100.0 & 20.0 & 260 & 20.00 & 34.00 & 40.24 \\
\hline 42187 & DARST CREEK BUDA & 1 & GULF COAST BASIN & BUDA LIME & LS & SG & 2200.0 & 90.0 & & 0.10 & 32.00 & 63.20 \\
\hline 42187 & DARST CREEK EDWARDS & 1 & GULF COAST BASIN & EDWARDS & $D O, L S$ & WD & 2600.0 & 150.0 & 200 & 200.00 & 36.00 & 93.50 \\
\hline 42013 & JOURDANTON EDWARDS & 1 & GULF COAST BASIN & EDWARDS & DO,LS & WD+MGCE & 7300.0 & 55.0 & 400 & 23.00 & 38.00 & 13.60 \\
\hline 42055 & LULING-BRANYON AUSTIN & 1 & GULF COAST BASIN & AUSTIN CHALK & LS & SG & 1900.0 & 30.0 & 300 & 0.10 & 36.00 & 160.75 \\
\hline 42055 & LULING-BRANYON EDWARDS & 1 & GULF COAST BASIN & EDWARDS & $D O, L S$ & WD & 2200.0 & 0.0 & 150 & 200.00 & 36.00 & 138.00 \\
\hline 42055 & LYTTON SPRINGS & 1 & GULF COAST BASIN & TAYLOR & TUFF & $S G+G D$ & 1300.0 & 0.0 & & 7.00 & 38.00 & 11.27 \\
\hline 42163 & PEARSALL AUSTIN CHALK & 1 & GULF COAST BASIN & AUSTIN CHALK & LS & SG,GD & 5300.0 & 40.0 & & 0.10 & 28.00 & 72.75 \\
\hline 42323 & SACATOSA SAN MIGUEL & 1 & GULF COAST BASIN & SAN MIGUEL & SS & SG & 1200.0 & 22.0 & 615 & 4.00 & 32.00 & 30.36 \\
\hline 42055 & SALT FLAT AUSTIN CHALK & 1 & GULF COAST BASIN & AUSTIN CHALK & LS & SG & 2400.0 & 120.0 & 500 & 0.10 & 36.00 & 78.57 \\
\hline 42055 & SALT FLAT EDWARDS & 1 & GULF COAST BASIN & EDWARDS & $D O, L S$ & WD & 2725.0 & 15.0 & & & 30.00 & 63.70 \\
\hline 42013 & SOMERSET OLMOS B & 1 & GULF COAST BASIN & OLMOS & SS & SG & 1000.0 & 10.0 & & 85.00 & 34.00 & 26.28 \\
\hline 42013 & WEIGANG CARRIZO & 1 & GULF COAST BASIN & CARRIZO WILCOX & SS & WD & 3900.0 & 30.0 & & 1357.00 & 24.00 & 11.19 \\
\hline 42175 & BERCLAIR VICKSBURG & 2 & GULF COAST BASIN & VICKSBURG & SS & COMBINED & 3200.0 & & 23 & 1000.00 & 27.00 & 12.13 \\
\hline 42469 & BLOOMINGTON 4600 & 2 & GULF COAST BASIN & GRETA & SS & WD & 4600.0 & 20.0 & 40 & 1140.00 & 23.00 & 31.57 \\
\hline 42391 & BONNIE VIEW & 2 & GULF COAST BASIN & GRETA & SS & WD & 4500.0 & 24.0 & 30 & 1000.00 & 24.00 & 19.62 \\
\hline 42123 & COTTONWOOD CR. SOUTH & 2 & GULF COAST BASIN & WILCOX & SS & WD+GCE & 7600.0 & 22.0 & 20 & 790.00 & 36.00 & 11.09 \\
\hline 42255 & FALLLS CITY LBAR., LPA. & 2 & GULF COAST BASIN & LOWER WILCOX & ss & WD & 6100.0 & 25.0 & 50 & 371.00 & 39.00 & 25.40 \\
\hline 42239 & FRANCITAS NORTH & 2 & GULF COAST BASIN & FRIO & ss & COMBINED & 8500.0 & & 18 & 1800.00 & 49.00 & 11.81 \\
\hline 42239 & GANADO WEST 4700 & 2 & GULF COAST BASIN & GRETA & ss & WD & 4700.0 & 44.0 & 80 & 1411.00 & 24.00 & 27.60 \\
\hline 42391 & GRETA 4400 & 2 & GULF COAST BASIN & FRIO & ss & WD & 4400.0 & 25.0 & 65 & 687.00 & 24.00 & 133.23 \\
\hline 42469 & HELEN GOHLKE WILCOX & 2 & GULF COAST BASIN & WILCOX & SS & WD+GCE & 8100.0 & 47.0 & 65 & 180.00 & 34.00 & 24.18 \\
\hline 42057 & HEYSER 5400 & 2 & GULF COAST BASIN & FRIO & SS & WD+MSG & 5400.0 & 13.0 & 36 & 300.00 & 34.00 & 10.40 \\
\hline 42391 & LA ROSA 5400 & 2 & GULF COAST BASIN & FRIO & ss & WD & 5400.0 & & 39 & 0.00 & 30.00 & 10.00 \\
\hline 42391 & LA ROSA 5900 & 2 & GULF COAST BASIN & FRIO & SS & WD+GCE & 5900.0 & 24.0 & 25 & 1682.00 & 30.00 & 15.53 \\
\hline 42239 & LA WARD NORTH & 2 & GULF COAST BASIN & MARGINULINA & SS & GCE +MWD & 5200.0 & 18.0 & 33 & 350.00 & 26.00 & 19.52 \\
\hline 42391 & LAKE PASTURE H-440 S & 2 & GULF COAST BASIN & UPPER GRETA & SS & WD+SG & 4500.0 & 75.0 & 50 & 1197.00 & 24.00 & 51.82 \\
\hline 42239 & LOLITA MARGINULINA & 2 & GULF COAST BASIN & MARGINULINA & ss & WD+PSG & 5300.0 & 7.0 & 25 & 164.00 & 26.00 & 15.56 \\
\hline 42239 & LOLITA WARD ZONE & 2 & GULF COAST BASIN & FRIO & ss & WD & 5900.0 & 10.0 & 30 & 635.00 & 32.00 & 14.36 \\
\hline 42239 & MAURBRO MARGINULINA & 2 & GULF COAST BASIN & MARGINULINA & ss & WD+GCE & 5200.0 & 9.0 & 34 & 450.00 & 25.00 & 26.03 \\
\hline 42469 & MCFADDIN 4400 & 2 & GULF COAST BASIN & GRETA & SS & WD & 4400.0 & 40.0 & 53 & 287.00 & 25.00 & 30.33 \\
\hline 42391 & M. E. O'CONNOR FQ-40 & 2 & GULF COAST BASIN & FRIO & Ss & WD & 5900.0 & 20.0 & & 820.00 & 40.00 & 18.07 \\
\hline 42255 & PERSON EDWARDS & 2 & GULF COAST BASIN & EDWARDS & DO,LS & GCE & 10850.0 & 30.0 & 120 & 2.60 & 40.00 & 16.65 \\
\hline 42025 & PETTUS PETTUS & 2 & GULF COAST BASIN & PETTUS & SS & GCE & 3900.0 & 16.0 & 81 & 452.00 & 44.00 & 16.54 \\
\hline
\end{tabular}


i Table A1. Texas Reservoir Database (Continued)

\begin{tabular}{|c|c|c|c|c|c|c|c|c|c|c|c|c|}
\hline $\begin{array}{l}\text { CNTY } \\
\text { CODE }\end{array}$ & FIELD_RES & $\begin{array}{l}\text { RRC } \\
\text { DIST }\end{array}$ & PROVINCE & $\begin{array}{l}\text { PRODUCING } \\
\text { FORMATION }\end{array}$ & LITH & DRIVE & DEPTH & $\begin{array}{l}\text { NET } \\
\text { PAY }\end{array}$ & $\begin{array}{c}\text { OIL } \\
\text { COLUMN }\end{array}$ & $\begin{array}{l}\text { AVG. } \\
\text { PERM }\end{array}$ & API & $\begin{array}{l}\text { CUMULATIVE } \\
\text { PRODUCTION }\end{array}$ \\
\hline 42469 & PLACEDO 4700 SAND & 2 & GULF COAST BASIN & GRETA & SS & WD & 4700.0 & 0.0 & 40 & 847.00 & 24.00 & 43.08 \\
\hline 42123 & SLICK WILCOX & 2 & GULF COAST BASIN & WILCOX & SS & WD+MGCE & 7300.0 & 50.0 & 50 & 350.00 & 36.00 & 19.91 \\
\hline 42391 & TOM O'CONNOR 4400 & 2 & GULF COAST BASIN & FRIO & SS & SG+WD & 4400.0 & 4.2 & 15 & 578.00 & 24.00 & 14.22 \\
\hline 42391 & TOM O'CONNOR $4500 \mathrm{GR}$. & 2 & GULF COAST BASIN & GRETA & SS & WD & 4500.0 & 20.0 & 20 & 2290.00 & 24.00 & 18.90 \\
\hline 42391 & TOM O'CONNOR 5500 & 2 & GULF COAST BASIN & LOWER FRIO & SS & SG+PWD & 5500.0 & 26.0 & 80 & 816.00 & 31.00 & 113.50 \\
\hline 42391 & TOM O'CONNOR 5800 & 2 & GULF COAST BASIN & FRIO & SS & COMBINED & 5800.0 & 16.0 & 200 & 1758.00 & 36.00 & 248.16 \\
\hline 42391 & TOM O'CONNOR 5900 & 2 & GULF COAST BASIN & FRIO & SS & WD & 5900.0 & 30.0 & 150 & 2136.00 & 35.00 & 262.77 \\
\hline 42239 & WEST RANCH 41-A & 2 & GULF COAST BASIN & FRIO & SS & WD & 5700.0 & 35.0 & 60 & 869.00 & 32.00 & 99.04 \\
\hline 42239 & WEST RANCH 98-A & 2 & GULF COAST BASIN & FRIO & SS & WD & 6100.0 & 32.0 & 70 & 497.00 & 40.00 & 59.00 \\
\hline 42239 & WEST R'NCH GLASSCOCK & 2 & GULF COAST BASIN & FRIO & SS & GCE+WD & 5500.0 & 36.0 & 95 & 394.00 & 31.00 & 45.74 \\
\hline 42239 & WEST RANCH GRETA & 2 & GULF COAST BASIN & GRETA & SS & WD & 5100.0 & 33.0 & 48 & 1000.00 & 24.00 & 99.24 \\
\hline 42239 & WEST RANCH WARD & 2 & GULF COAST BASIN & FRIO & SS & WD+GCE & 5700.0 & 13.0 & 30 & 1228.00 & 31.00 & 30.28 \\
\hline 42245 & AMELIA FRIO 6 & 3 & GULF COAST BASIN & FRIO & SS & WD+GCE & 6800.0 & 12.0 & 20 & 1390.00 & 30.00 & 27.50 \\
\hline 42071 & ANAHUAC MAIN FRIO & 3 & GULF COAST BASIN & FRIO & SS & WD+GCE & 7100.0 & 66.0 & 125 & 1085.00 & 35.00 & 275.87 \\
\hline 42199 & BATSON CAPROCK & 3 & GULF COAST BASIN & CAPROCK & LS & GCE+GD & 1100.0 & 26.0 & & & 30.00 & 44.94 \\
\hline 42071 & CEDAR POINT FRIO 5900 & 3 & GULF COAST BASIN & FRIO & SS & WD+GCE & 6000.0 & 9.0 & 75 & 900.00 & 38.00 & 18.56 \\
\hline 42039 & CHOCOLATE BAYOU, ALI. & 3 & GULF COAST BASIN & ALIBEL FRIO & ss & WD & 9400.0 & 26.0 & 52 & 400.00 & 42.00 & 14.43 \\
\hline 42039 & CHOCOLATE BAYOU, U.F. & 3 & GULF COAST BASIN & UPPER FRIO & SS & GCE+WD & 8800.0 & 27.0 & 20 & 1090.00 & 42.00 & 17.45 \\
\hline 42201 & CLEAR LAKE FRIO & 3 & GULF COAST BASIN & FRIO & SS & WD+GCE & 5900.0 & 40.0 & 60 & 977.00 & 26.00 & 23.99 \\
\hline 42339 & CONROE MAIN CONROE & 3 & GULF COAST BASIN & COCKFIELD & ss & WD+GCE & 5200.0 & 65.0 & 160 & 1400.00 & 38.00 & 706.37 \\
\hline 42201 & DURKEE FAIRBANKS & 3 & GULF COAST BASIN & FAIRBANKS & SS & WD+GCE & 7100.0 & 25.0 & 40 & 2400.00 & 35.00 & 13.24 \\
\hline 42291 & $\begin{array}{l}\text { ESPERSON DOME S. } \\
\text { CROCKETT }\end{array}$ & 3 & GULF COAST BASIN & CROCKETT & SS & COMBINED & 7300.0 & 176.0 & 1800 & 240.00 & 39.00 & 17.34 \\
\hline 42201 & FAIRBANKS FAIRBANKS & 3 & GULF COAST BASIN & YEGUA & SS & GCE & 6800.0 & 91.0 & 26 & 2000.00 & 36.00 & 41.24 \\
\hline 42071 & FIG RIDGE SEABREEZE & 3 & GULF COAST BASIN & FRIO & SS & SG+WD & 8500.0 & 34.0 & 100 & 750.00 & 35.00 & 48.77 \\
\hline 42287 & GIDDINGS AUSTIN CHALK & 3 & GULF COAST BASIN & AUSTIN CHALK & LS & SG & 7500.0 & 150.0 & & 0.10 & 40.00 & 193.47 \\
\hline 42167 & GILLOCK BIG GAS & 3 & GULF COAST BASIN & FRIO & SS & COMBINED & 8400.0 & 25.0 & 505 & 1470.00 & 38.00 & 34.01 \\
\hline 42167 & GILLOCK EAST SEGMENT & 3 & GULF COAST BASIN & FRIO & SS & WD & 9600.0 & 42.5 & 370 & 1330.00 & 39.00 & 21.94 \\
\hline 42167 & GILLOCK, S. BIG GAS & 3 & GULF COAST BASIN & FRIO & ss & WD+GCE & 9600.0 & 36.0 & 574 & 900.00 & 38.00 & 45.46 \\
\hline 42291 & HARDIN FRAZIER & 3 & GULF COAST BASIN & COCKFIELD & SS & WD & 7900.0 & 26.0 & 100 & 500.00 & 38.00 & 22.35 \\
\hline 42039 & HASTINGS, E. U. FRIO & 3 & GULF COAST BASIN & UPPER FRIO & ss & WD+GCE & 6100.0 & 8.0 & 145 & 720.00 & 32.00 & 56.88 \\
\hline 42039 & HASTINGS, W. FRIO & 3 & GULF COAST BASIN & FRIO & ss & COMBINED & 6100.0 & 163.0 & 625 & 865.00 & 31.00 & 619.15 \\
\hline 42201 & HOUSTON, S. FRIO & 3 & GULF COAST BASIN & FRIO & ss & WD+GCE & 4800.0 & 0.0 & 295 & 710.00 & 27.00 & 42.37 \\
\hline 42201 & HOUSTON, S. MIOCENE & 3 & GULF COAST BASIN & MIOCENE & SS & WD+GCE & 4000.0 & 0.0 & 180 & 100.00 & 22.00 & 14.90 \\
\hline 42201 & HUMBLE CAPROCK & 3 & GULF COAST BASIN & CAPROCK & LS & GCE+GD & 1200.0 & 80.0 & & 0.00 & 22.00 & 168.13 \\
\hline 42473 & KATY I-B & 3 & GULF COAST BASIN & YEGUA & SS & GCE+WD & 6600.0 & 18.0 & 12 & 1050.00 & 43.00 & 15.10 \\
\hline
\end{tabular}


Table A1. Texas Reservoir Database (Continued)

\begin{tabular}{|c|c|c|c|c|c|c|c|c|c|c|c|c|}
\hline $\begin{array}{l}\text { CNTY } \\
\text { CODE }\end{array}$ & FIELD_RES & $\begin{array}{l}\text { RRC } \\
\text { DIST }\end{array}$ & PROVINCE & $\begin{array}{l}\text { PRODUCING } \\
\text { FORMATION }\end{array}$ & LITH & DRIVE & DEPTH & $\begin{array}{l}\text { NET } \\
\text { PAY }\end{array}$ & $\begin{array}{c}\text { OIL } \\
\text { COLUMN }\end{array}$ & $\begin{array}{l}\text { AVG. } \\
\text { PERM }\end{array}$ & API & $\begin{array}{l}\text { CUMULATIVE } \\
\text { PRODUCTION }\end{array}$ \\
\hline 42041 & KURTEN WOODBINE & 3 & EAST TEXAS & WOODBINE & ss & SG & 8300.0 & 27.0 & & 2.00 & 38.00 & 13.76 \\
\hline 42373 & LIVINGSTON WILCOX & 3 & GULF COAST BASIN & WILCOX & ss & WD & 7400.0 & 81.0 & 80 & 70.00 & 35.00 & 19.95 \\
\hline 42373 & LIVINGSTON YEGUA & 3 & GULF COAST BASIN & YEGUA & sS & WD+GCE & 4500.0 & 15.0 & 45 & 120.00 & 40.00 & 20.66 \\
\hline 42245 & LOVELL'S LAKE FRIO 1 & 3 & GULF COAST BASIN & FRIO & SS & WD+GCE & 7700.0 & 45.0 & 10 & 450.00 & 38.00 & 10.30 \\
\hline 42245 & LOVELL'S LAKE FRIO 2 & 3 & GULF COAST BASIN & FRIO & ss & WD+GCE & 7900.0 & 0.0 & 50 & 454.00 & 38.00 & 17.03 \\
\hline 42481 & MAGNET-WITHERS & 3 & GULF COAST BASIN & FRIO & SS & WD+GCE & 5600.0 & 67.0 & 20 & 1700.00 & 26.00 & 91.99 \\
\hline 42039 & MANVEL F.B. I OLIG. & 3 & GULF COAST BASIN & OLIGOCENE & SS & WD+GCE & 5100.0 & 48.0 & 129 & 500.00 & 28.00 & 42.32 \\
\hline 42039 & MANVEL F.B. \| OLIG. & 3 & GULF COAST BASIN & OLIGOCENE & ss & WD+GCE & 5700.0 & 48.0 & 126 & 500.00 & 28.00 & 34.14 \\
\hline 42321 & MARKHAM N.-BCN CARLSON . & 3 & GULF COAST BASIN & FRIO & SS & WD+GCE & 7000.0 & & 25 & 3333.00 & 36.00 & 13.81 \\
\hline 42321 & MARKHAM N.-BCN CORNELIUS & 3 & GULF COAST BASIN & FRIO & ss & $W D+G C E$ & 8400.0 & & 40 & 750.00 & 36.00 & 18.19 \\
\hline 42291 & MERCHANTEY-1B & 3 & GULF COAST BASIN & YEGUA & ss & COMBINED & 8900.0 & 28.0 & 918 & 230.00 & 30.00 & 23.21 \\
\hline 42407 & MERCY 8260 WILCOX & 3 & GULF COAST BASIN & WILCOX & ss & WD & 8300.0 & 15.0 & 37 & 256.00 & 38.00 & 13.33 \\
\hline 42039 & OLD OCEAN ARMSTRONG & 3 & GULF COAST BASIN & FRIO & ss & GCE & 10000.0 & & 83 & 251.00 & 37.00 & 68.09 \\
\hline 42039 & OLD OCEAN CHENAULT & 3 & GULF COAST BASIN & FRIO & ss & GCE & 9600.0 & 60.0 & 60 & 640.00 & 36.00 & 10.16 \\
\hline 42071 & OYSTER BAYOU SEABREEZE & 3 & GULF COAST BASIN & SEABREEZE & ss & WD+GCE & 8300.0 & 150.0 & 177 & 1325.00 & 36.00 & 138.19 \\
\hline 42481 & PICKETT RIDGE & 3 & GULF COAST BASIN & FRIO & ss & WD+GCE & 4700.0 & 10.0 & 80 & 312.00 & 25.00 & 16.08 \\
\hline 42015 & RACCOON BEND COCKFIELD & 3 & GULF COAST BASIN & COCKFIELD & ss & WD & 4200.0 & 40.9 & & 840.00 & 34.00 & 59.00 \\
\hline 42373 & SEGNO YEGUA & 3 & GULF COAST BASIN & YEGUA & ss & COMBINED & 5200.0 & & 10 & 713.00 & 41.00 & 11.52 \\
\hline 42373 & SEGNO, DEEP WILCOX & 3 & GULF COAST BASIN & UPPER WILCOX & ss & SG+WD & 8200.0 & & & & 38.00 & 14.90 \\
\hline 42199 & SILSBEE FIRST YEGUA & 3 & GULF COAST BASIN & YEGUA & ss & $W D+G C E$ & 7000.0 & 0.0 & 25 & 500.00 & 41.00 & 23.63 \\
\hline 42199 & SOUR LAKE CAPROCK & 3 & GULF COAST BASIN & CAPROCK & LS & $G C E+G D$ & 600.0 & 20.0 & & & 22.00 & 132.75 \\
\hline 42245 & SPINDLETOP CAPROCK & 3 & GULF COAST BASIN & CAPROCK & LS & $G C E+G D$ & 800.0 & 40.0 & & & 22.00 & 154.68 \\
\hline 42321 & SUGAR VALLEY N. LAURENCE & 3 & GULF COAST BASIN & FRIO & ss & WD+GCE & 8900.0 & 0.0 & 37 & 600.00 & 32.00 & 6.30 \\
\hline 42157 & SUGARLAND UPPER FRIO & 3 & GULF COAST BASIN & UPPER FRIO & ss & $G C E+W D$ & 3800.0 & 85.0 & 575 & 900.00 & 29.00 & 73.25 \\
\hline 42157 & THOMPSON FRIO & 3 & GULF COAST BASIN & FRIO & ss & $W D+G C E$ & 5400.0 & 40.0 & 250 & 1100.00 & 25.00 & 360.42 \\
\hline 42157 & THOMPSON, N. U. VICKSBURG & 3 & GULF COAST BASIN & JUPPER VICKSBURG & SS & $W D+S G$ & 7800.0 & & 150 & 3400.00 & 36.00 & 28.28 \\
\hline 42157 & THOMPSON, S. $4400^{\circ}$ & 3 & GULF COAST BASIN & MIOCENE & ss & WD & 4400.0 & 35.0 & 130 & 367.00 & 25.00 & 24.80 \\
\hline 42157 & THOMPSON, S. 5400 & 3 & GULF COAST BASIN & MARGINULINA & SS & WD+GCE & 5300.0 & 29.0 & 80 & 900.00 & 25.00 & 10.70 \\
\hline 42201 & TOMBALL KOBS & 3 & GULF COAST BASIN & COCKFIELD & SS & WD+GCE & 5500.0 & 6.5 & 20 & 1000.00 & 40.00 & 59.55 \\
\hline 42201 & TOMBALL SCHULTZ SE & 3 & GULF COAST BASIN & COCKFIELD & ss & WD+GCE & 5500.0 & 11.0 & 20 & 1200.00 & 40.00 & 37.20 \\
\hline 42071 & TRINITY BAY FRIO 12 & 3 & GULF COAST BASIN & FRIO & ss & WD+GCE & 8100.0 & 7.0 & 11 & 2344.00 & 36.00 & 24.16 \\
\hline 42071 & TURTLE BAY MIDDLETON & 3 & GULF COAST BASIN & FRIO & ss & WD & 6600.0 & 10.0 & 40 & 1000.00 & 31.00 & 12.29 \\
\hline 42201 & WEBSTER UPPER FRIO & 3 & GULF COAST BASIN & UPPER FRIO & SS & WD+GCE & 5800.0 & 150.0 & 400 & 2350.00 & 29.00 & 571.50 \\
\hline 42481 & WITHERS NORTH & 3 & GULF COAST BASIN & MARGINULINA & ss & WD+GCE & 5300.0 & 16.0 & 70 & 2500.00 & 26.00 & 50.30 \\
\hline 42007 & ARANSAS PASS & 4 & GULF COAST BASIN & FRIO & ss & $S G+M W D$ & 7100.0 & 20.0 & 16 & 225.00 & 42.00 & 20.27 \\
\hline 42355 & ARNOLD DAVID CHAPMAN & 4 & GULF COAST BASIN & FRIO & Ss & WD & 6100.0 & 20.0 & 69 & 917.00 & 42.00 & 10.52 \\
\hline
\end{tabular}


Table A1. Texas Reservoir Database (Continued)

\begin{tabular}{|c|c|c|c|c|c|c|c|c|c|c|c|c|}
\hline $\begin{array}{l}\text { CNTY } \\
\text { CODE }\end{array}$ & - FIELD_RES & \begin{tabular}{|l|} 
RRC \\
DIST
\end{tabular} & PROVINCE & $\begin{array}{l}\text { PRODUCING } \\
\text { FORMATION }\end{array}$ & LITH & DRIVE & DEPTH & $\begin{array}{l}\text { NET } \\
\text { PAY }\end{array}$ & $\begin{array}{c}\text { OIL } \\
\text { COLUMN }\end{array}$ & $\begin{array}{l}\text { AVG. } \\
\text { PERM }\end{array}$ & API & $\begin{array}{l}\text { CUMULATIVE } \\
\text { PRODUCTION }\end{array}$ \\
\hline 42479 & AVIATORS MIRANDO & 4 & GULF COAST BASIN & MIRANDO & ss & $S G+W D$ & 1700.0 & 13.0 & 51 & 357.00 & 21.00 & 10.37 \\
\hline 42247 & COLORADO COCKFIELD & 4 & GULF COAST BASIN & COCKFIELD & ss & SG & 2600.0 & & 300 & 800.00 & 45.00 & 21.91 \\
\hline 42131 & CONOCO DRISCOLL U.1G.W. & 4 & GULF COAST BASIN & $\begin{array}{l}\text { GOVERNMENT } \\
\text { WELLS }\end{array}$ & ss & GCE & 2800.0 & 12.0 & 54 & 458.00 & 33.00 & 29.44 \\
\hline 42505 & ESCOBAS MIRANDO & 4 & GULF COAST BASIN & MIRANDO & ss & SG & 1200.0 & 17.0 & 70 & 500.00 & 23.00 & 13.07 \\
\hline 42355 & FLOUR BLUFF PHILLIPS & 4 & GULF COAST BASIN & FRIO & ss & GCE+WD & 6600.0 & 25.0 & 20 & 745.00 & 44.00 & 18.73 \\
\hline 42427 & GARCIA GARCIA MAIN & 4 & GULF COAST BASIN & VICKSBURG & ss & LWD+GCE & 3800.0 & 12.0 & 80 & 1285.00 & 47.00 & 29.18 \\
\hline 42131 & GOVT. WELLLS, NORTH G.W. & 4 & GULF COAST BASIN & $\begin{array}{l}\text { GOVERNMENT } \\
\text { WELLS }\end{array}$ & ss & $S G+W D$ & 2200.0 & 20.0 & 60 & 800.00 & 21.00 & 80.03 \\
\hline 42131 & GOVT. WELLS, SOUTH G.W. & 4 & GULF COAST BASIN & $\begin{array}{l}\text { GOVERNMENT } \\
\text { WELLS }\end{array}$ & ss & SG & 2300.0 & & 89 & 600.00 & 21.00 & 18.15 \\
\hline 42131 & HOFFMAN DOUGHERTY & 4 & GULF COAST BASIN & JACKSON & ss & SG & 2000.0 & 10.0 & 250 & 757.00 & 23.00 & 48.81 \\
\hline 42247 & KELSEY M-2 & 4 & GULF COAST BASIN & CATAHOULA & ss & GCE+SG & 4700.0 & 16.0 & 93 & 454.00 & 47.00 & 10.80 \\
\hline 42131 & LOMA NOVIA LOMA NOVIA & 4 & GULF COAST BASIN & LOMA NOVIA & ss & SG & 2600.0 & 16.0 & 240 & 800.00 & 26.00 & 48.61 \\
\hline 42355 & LONDON GIN DOUGHTY & 4 & GULF COAST BASIN & CATAHOULA & ss & WD & 4500.0 & 14.0 & 47 & 1698.00 & 32.00 & 14.40 \\
\hline 42479 & LOPEZ FIRST MIRANDO & 4 & GULF COAST BASIN & MIRANDO & SS & COMBINED & 2200.0 & 15.0 & 70 & 250.00 & 22.00 & 31.35 \\
\hline 42409 & MIDWAY MAIN MIDWAY & 4 & GULF COAST BASIN & MIDWAY & ss & WD+GCE & 5300.0 & 25.0 & 15 & 4500.00 & 27.00 & 16.60 \\
\hline 42479 & MIRANDO CITY MIRANDO & 4 & GULF COAST BASIN & MIRANDO & SS & COMBINED & 1600.0 & 26.0 & 35 & 1600.00 & 21.00 & 12.30 \\
\hline 42479 & O'HERN PETTUS & 4 & GULF COAST BASIN & PETTUS & sS & SG & 2700.0 & 23.0 & 200 & 286.00 & 28.00 & 22.46 \\
\hline 42131 & PIEDRE LUMBRE G.W. & 4 & GULF COAST BASIN & $\begin{array}{l}\text { GOVERNMENT } \\
\text { WELLS }\end{array}$ & SS & WD+SG & 1900.0 & 15.0 & 65 & 300.00 & 22.00 & 21.13 \\
\hline 42409 & PLYMOUTH HEEP & 4 & GULF COAST BASIN & FRIO & ss & WD+GCE & 5600.0 & 28.0 & 30 & 3300.00 & 31.00 & 53.40 \\
\hline 42409 & PORTILLA 7300 & 4 & GULF COAST BASIN & FRIO & ss & WD & 7300.0 & 10.0 & 44 & 1412.00 & 40.00 & 12.61 \\
\hline 42409 & PORTILLA 7400 & 4 & GULF COAST BASIN & FRIO & ss & WD & 7400.0 & 28.0 & 130 & 1634.00 & 40.00 & 44.84 \\
\hline 42247 & PRADO MIDDLE LOMA NOVIA & 4 & GULF COAST BASIN & LOMA NOVIA & ss & SG+GCE & 3700.0 & 10.0 & 65 & 850.00 & 40.00 & 23.66 \\
\hline 42427 & RINCON FRIO D-5 & 4 & GULF COAST BASIN & FRIO & SS & COMBINED & 3800.0 & 13.0 & 149 & 206.00 & 38.00 & 8.10 \\
\hline 42427 & RINCONFRIOE1+E2 & 4 & GULF COAST BASIN & FRIO & SS & GCE & 4000.0 & 10.0 & 157 & 161.00 & 40.00 & 9.70 \\
\hline 42427 & RINCON VICKSBURG SAND & 4 & GULF COAST BASIN & VICKSBURG & ss & COMBINED & 5300.0 & 50.0 & 570 & 284.00 & 44.00 & 17.83 \\
\hline 42249 & SEELIGSON ZONE 10 & 4 & GULF COAST BASIN & FRIO & sS & GCE +LWD & 4600.0 & 0.0 & 24 & 766.00 & 39.00 & 11.00 \\
\hline 42249 & SEELIGSON ZONE 14-B & 4 & GULF COAST BASIN & FRIO & ss & GCE+WD & 5100.0 & 11.0 & 35 & 353.00 & 40.00 & 18.13 \\
\hline 42249 & SEELIGSON ZONE 16 & 4 & GULF COAST BASIN & FRIO & ss & GCE & 5700.0 & & & 214.00 & 40.00 & 11.00 \\
\hline 42249 & SEELIGSON ZONE 19-B & 4 & GULF COAST BASIN & FRIO & ss & GCE & 6100.0 & 16.0 & 175 & 546.00 & 41.00 & 17.32 \\
\hline 42249 & SEELIGSON ZONE 19-C-4 & 4 & GULF COAST BASIN & FRIO & ss & GCE & 5900.0 & 25.0 & 212 & 585.00 & 43.00 & 80.00 \\
\hline 42249 & SEELIGSON ZONE 20-C & 4 & GULF COAST BASIN & FRIO & ss & GCE & 6100.0 & & 42 & 513.00 & 40.00 & 10.00 \\
\hline 42131 & SEVEN SISTERS G.W. & 4 & GULF COAST BASIN & $\begin{array}{l}\text { GOVERNMENT } \\
\text { WELLSS }\end{array}$ & ss & $S G+W D$ & 2330.0 & 16.0 & 75 & 225.00 & 20.00 & 55.96 \\
\hline
\end{tabular}


Table A1. Texas Reservoir Database (Continued)

\begin{tabular}{|c|c|c|c|c|c|c|c|c|c|c|c|c|}
\hline $\begin{array}{l}\text { CNTY } \\
\text { CODE }\end{array}$ & FIELD_RES & $\begin{array}{l}\text { RRC } \\
\text { DIST }\end{array}$ & PROVINCE & $\begin{array}{l}\text { PRODUCING } \\
\text { FORMATION }\end{array}$ & LITH & DRIVE & DEPTH & $\begin{array}{l}\text { NET } \\
\text { PAY }\end{array}$ & $\begin{array}{c}\text { OIL } \\
\text { COLUMN }\end{array}$ & $\begin{array}{l}\text { AVG. } \\
\text { PERM }\end{array}$ & API & $\begin{array}{l}\text { CUMULATIVE } \\
\text { PRODUCTION }\end{array}$ \\
\hline 42355 & $\begin{array}{l}\text { STRATTON BERTRAM } \\
\text { WARDNER }\end{array}$ & 4 & GULF COAST BASIN & FRIO & ss & GCE & 6500.0 & 23.0 & 200 & 220.00 & 43.00 & 18.60 \\
\hline 42427 & SUN FRIO D-1 & 4 & GULF COAST BASIN & FRIO & SS & GCE & 4300.0 & 13.0 & 109 & 549.00 & 45.00 & 26.12 \\
\hline 42409 & TAFT 4000 & 4 & GULF COAST BASIN & CATAHOULA & SS & WD & 4000.0 & 30.0 & 73 & 1500.00 & 23.00 & 25.28 \\
\hline 42273 & T.C.B. 21-B & 4 & GULF COAST BASIN & FRIO & SS & GCE & 7100.0 & & 117 & 186.00 & 40.00 & 45.00 \\
\hline 42249 & WADE CITY BIERSTADT & 4 & GULF COAST BASIN & FRIO & ss & WD & 4800.0 & 12.0 & & & 29.00 & 10.08 \\
\hline 42409 & WHITE POINT E. BRIGHTON & 4 & GULF COAST BASIN & FRIO & ss & WD & 5700.0 & 26.0 & 82 & 575.00 & 39.00 & 86.69 \\
\hline 42489 & WILLAMAR WILLAMAR & 4 & GULF COAST BASIN & WILLAMAR & ss & $S G+G C E$ & 7600.0 & 20.0 & 143 & 140.00 & 30.00 & 26.05 \\
\hline 42489 & WILLAMAR, W. W. WILLA. & 4 & GULF COAST BASIN & WILLAMAR & ss & SG+GCE & 7900.0 & 34.0 & 160 & 65.00 & 31.00 & 53.20 \\
\hline 42223 & BRANTLEY JACKSON SMACK. & 5 & EAST TEXAS & SMACKOVER & DO,LS & SG & 9200.0 & 50.0 & 240 & 25.00 & 40.00 & 15.62 \\
\hline 42349 & CHENEYBORO COTTON VAL. & 5 & EAST TEXAS & COTTON VALLEY & LS & SG & 9700.0 & 15.0 & & 12.00 & 50.00 & 2.00 \\
\hline 42349 & CORSICANA SHALLOW & 5 & EAST TEXAS & NAVARRO & ss & COMBINED & 1200.0 & & 84 & 28.00 & 36.00 & 43.44 \\
\hline 42293 & MEXIA WOODBINE & 5 & EAST TEXAS & WOODBINE & SS & WD & 3000.0 & 40.0 & 110 & 1600.00 & 35.00 & 109.32 \\
\hline 42223 & PICKTON BACON LIME & 5 & EAST TEXAS & BACON LIME & LS & SG & 7900.0 & 8.1 & 37 & 252.00 & 46.00 & 16.32 \\
\hline 42349 & POWELL WOODBINE & 5 & EAST TEXAS & WOODBINE & ss & WD & 2900.0 & 88.0 & 150 & 1600.00 & 36.00 & 131.40 \\
\hline 42223 & SULPHUR BLUFF PALUXY & 5 & EAST TEXAS & PALUXY & ss & WD & 4500.0 & 60.0 & 150 & 4000.00 & 21.00 & 32.14 \\
\hline 42467 & VAN WOODBINE & 5 & EAST TEXAS & WOODBINE & ss & WD & 2700.0 & 250.0 & 700 & 1000.00 & 34.00 & 584.70 \\
\hline 42161 & WORTHAM WOODBINE & 5 & EAST TEXAS & WOODBINE & SS & WD & 2900.0 & 24.0 & 50 & 1620.00 & 39.00 & 24.70 \\
\hline 42001 & FAIRWAY JAMES LIME & 56 & EAST TEXAS & JAMES LIME & LS & SG & 10000.0 & 70.0 & 130 & 18.00 & 48.00 & 187.86 \\
\hline 42365 & BETHANY GLEN ROSE, 4300 & 6 & EAST TEXAS & GLEN ROSE & LS & SG & 4300.0 & 7.0 & & 203.00 & 43.00 & 15.43 \\
\hline 42365 & BETHANY N.E. LIME, 3850 & 6 & EAST TEXAS & GLEN ROSE & LS & SG & 3900.0 & 9.0 & 30 & 28.00 & 43.00 & 13.95 \\
\hline 42001 & CAYUGA WOODBINE & 6 & EAST TEXAS & WOODBINE & ss & WD & 4000.0 & 35.0 & 20 & 500.00 & 29.00 & 62.76 \\
\hline 42499 & COKE PALUXY & 6 & EAST TEXAS & PALUXY & SS & WD & 6300.0 & 50.0 & 131 & 1175.00 & 27.00 & 29.84 \\
\hline 42499 & HAWKINS WOODBINE & 6 & EAST TEXAS & WOODBINE & SS & COMBINED & 4500.0 & 109.0 & 300 & 3394.00 & 24.00 & 814.21 \\
\hline 42315 & HAYNES MITCHELL & 6 & EAST TEXAS & MITCHELL & LS & SG & 5900.0 & 18.0 & 140 & 25.00 & 40.00 & 13.42 \\
\hline 42423 & HITTS LAKE PALUXY & 6 & EAST TEXAS & PALUXY & $\underline{s}$ & $S G+W D$ & 7200.0 & 32.0 & 130 & 400.00 & 26.00 & 13.61 \\
\hline 42067 & KILDARE RODESSA & 6 & EAST TEXAS & RODESSA & $L S, S S$ & $S G$ & 6000.0 & 17.0 & 60 & 27.00 & 40.00 & 12.99 \\
\hline 42001 & LONG LAKE WOODBINE & 6 & EAST TEXAS & WOODBINE & ss & SG+PWD & 5200.0 & 21.0 & 60 & 1085.00 & 40.00 & 36.49 \\
\hline 42499 & MANZIEL PALUXY & 6 & EAST TEXAS & PALUXY & SS & WD & 6300.0 & & 165 & 830.00 & 32.00 & 21.93 \\
\hline 42499 & MERIGALE-PAUL SUB-CL. & 6 & EAST TEXAS & SUB-CLARKSVILLE & Ss & SG & 4800.0 & 0.0 & 235 & 300.00 & 30.00 & 11.25 \\
\hline 42001 & NECHES WOODBINE & 6 & EAST TEXAS & WOODBINE & ss & WD & 4700.0 & 23.0 & 90 & 1020.00 & 40.00 & 98.84 \\
\hline 42459 & NEW DIANA WOODBINE & 6 & EAST TEXAS & WOODBINE & SS & WD & 3700.0 & 11.0 & 75 & 141.00 & 40.00 & 11.43 \\
\hline 42159 & NEW HOPE BACON LIME & 6 & EAST TEXAS & BACON LIME & LS & SG+MWD & 7400.0 & 11.0 & 120 & 379.00 & 44.00 & 15.45 \\
\hline 42159 & NEW HOPE PITTSBURG & 6 & EAST TEXAS & PITTSBURG & ss & SG+MWD & 8000.0 & 14.0 & 367 & 61.00 & 46.00 & 20.14 \\
\hline 42449 & PEWITT RANCH PALUXY & 6 & EAST TEXAS & PALUXY & ss & WD & 4300.0 & 29.0 & 78 & 2460.00 & 19.00 & 23.38 \\
\hline 42063 & PITTSBURG PITTSBURG & 6 & EAST TEXAS & PITTSBURG & SS & SG & 8000.0 & 19.0 & 107 & 40.00 & 42.00 & 15.13 \\
\hline
\end{tabular}


$\stackrel{\longrightarrow}{\circ}$ Table A1. Texas Reservoir Database (Continued)

\begin{tabular}{|c|c|c|c|c|c|c|c|c|c|c|c|c|}
\hline $\begin{array}{l}\text { CNTY } \\
\text { CODE }\end{array}$ & FIELD_RES & $\begin{array}{l}\text { RRC } \\
\text { DIST } \\
\end{array}$ & PROVINCE & \begin{tabular}{|l|} 
PRODUCING \\
FORMATION \\
\end{tabular} & LITH & DRIVE & DEPTH & \begin{tabular}{|l|} 
NET \\
PAY \\
\end{tabular} & $\begin{array}{c}\text { OIL } \\
\text { COLUMN }\end{array}$ & \begin{tabular}{|l|} 
AVG. \\
PERM \\
\end{tabular} & API & \begin{tabular}{|l} 
CUMULATIVE \\
PRODUCTION \\
\end{tabular} \\
\hline 42499 & QUITMAN EAGLE FORD & 6 & EAST TEXAS & EAGLE FORD & ss & $S G+W D$ & 4200.0 & 35.0 & 200 & 115.00 & 25.00 & $10 . \dot{65}$ \\
\hline 42499 & QUITMAN PALUXY & 6 & EAST TEXAS & PALUXY & ss & WD & 6200.0 & 20.0 & 150 & 599.00 & 43.00 & 77.65 \\
\hline 42067 & RODESSA & 6 & EAST TEXAS & RODESSA & LS,SS & COMBINED & 5700.0 & 20.0 & 80 & 61.00 & 43.00 & 67.00 \\
\hline 42423 & SAND FLAT PALUXXY & 6 & EAST TEXAS & PALUXY & ss & SG & 7000.0 & 30.0 & 251 & 277.00 & 29.00 & 33.24 \\
\hline 42423 & SHAMBURGER LAKE PALUXY & 6 & EAST TEXAS & PALUXY & ss & SG & 7300.0 & 28.0 & 585 & 200.00 & 32.00 & 29.63 \\
\hline 42449 & TALCO PALUXY & 6 & EAST TEXAS & PALUXY & ss & WD & 4300.0 & 44.0 & 200 & 2000.00 & 22.00 & 279.62 \\
\hline 42401 & EAST TEXAS WOODBINE & 6 & EAST TEXAS & WOODBINE & ss & WD & 3600.0 & 35.0 & 324 & 1300.00 & 38.00 & 5041.24 \\
\hline 42433 & BOYD CONGL. & $7 \mathrm{~B}$ & PERMIAN BASIN & $\begin{array}{l}\text { BEND } \\
\text { CONGLOMERATE }\end{array}$ & CONGL & SG+PWD & 6000.0 & 27.0 & 125 & 55.00 & 40.00 & 25.59 \\
\hline 42429 & BRECKENRIDGE POOL & $7 \mathrm{~B}$ & BEND ARCH & CADDO LIME & LS & SG & 3100.0 & 35.0 & 80 & 15.00 & 38.00 & 145.00 \\
\hline 42151 & CLAYTONVILLE CANYON & $7 B$ & PERMIAN BASIN & CANYON & LS & SG+PWD & 5700.0 & 155.0 & 820 & 10.00 & 42.00 & 63.09 \\
\hline 42417 & COOKRANCH COOK & $7 \mathrm{~B}$ & BEND ARCH & $\mathrm{COOK}$ & ss & SG & 1300.0 & 20.0 & & 380.00 & 38.00 & 11.66 \\
\hline 42429 & CURRY POOL & $7 \mathrm{~B}$ & BEND ARCH & CADDO LIME & LS & SG & 3200.0 & 37.0 & 90 & 12.00 & 40.00 & 6.00 \\
\hline 42429 & ELIASVILLE POOL & $7 \mathrm{~B}$ & BEND ARCH & CADDO LIME & LS & SG & 3300.0 & 27.0 & 90 & 8.00 & 39.00 & 28.00 \\
\hline 42433 & FLOWERS CANYON SAND & $7 B$ & PERMIAN BASIN & CANYON & ss & SG & 4100.0 & 15.0 & & 17.00 & 41.00 & 29.10 \\
\hline 42253 & GRIFFIN & $7 B$ & BEND ARCH & PALO PINTO LIME & LS & WD & 3300.0 & 32.0 & 55 & & 43.00 & 10.23 \\
\hline 42253 & HAMLIN EAST & $7 \mathrm{~B}$ & BEND ARCH & SWASTIKA & ss & SG+PWD & 3200.0 & 25.0 & 55 & 350.00 & 39.00 & 13.99 \\
\hline 42433 & KATZ & $7 \mathrm{~B}$ & PERMIAN BASIN & STRAWN & ss & WD & 4900.0 & 20.0 & 74 & 200.00 & 37.00 & 37.60 \\
\hline 42433 & KATZ 5100 & $7 B$ & PERMIAN BASIN & STRAWN & ss & $W D+S G$ & 5100.0 & 35.0 & 90 & 56.00 & 37.00 & 16.92 \\
\hline 42353 & LAKE TRAMMELL W. CANYON & $7 \mathrm{~B}$ & PERMIAN BASIN & CANYON & ss & SG & 5200.0 & 19.0 & 180 & 6.00 & 40.00 & 10.68 \\
\hline 42353 & NENA LUCIA STRAWN REEF & $7 \mathrm{~B}$ & PERMIAN BASIN & STRAWN & LS & $S G+G C E$ & 6900.0 & 52.0 & 230 & 5.00 & 46.00 & 33.67 \\
\hline 42433 & OLD GLORY & $7 B$ & PERMIAN BASIN & $\begin{array}{l}\text { BEND } \\
\text { CONGLOMERATE }\end{array}$ & Co,ss & SG+PWD & 5900.0 & 17.0 & 120 & 49.00 & 40.00 & 12.51 \\
\hline 42133 & RANGER & 78 & BEND ARCH & RANGER & SS,CO & $S G$ & 3400.0 & 26.0 & & 162.00 & 37.00 & 65.78 \\
\hline 42151 & ROUGH DRAW NOODLE CREEK & 78 & PERMIAN BASIN & NOODLE CREEK & LS & SG & 3900.0 & 5.0 & 140 & 178.00 & 42.00 & 10.44 \\
\hline 42151 & ROUND TOP PALO PINTO & $7 \mathrm{~B}$ & PERMIAN BASIN & PALO PINTO LIME & LS & $S G+W D$ & 4800.0 & 90.0 & 475 & 6.00 & 40.00 & 48.68 \\
\hline 42207 & SOJOURNER & 78 & PERMIAN BASIN & STRAWN & ss & SG & 5300.0 & 19.0 & 115 & 15.00 & 41.00 & 10.14 \\
\hline 42461 & AMACKER-TIPPETT ELL. & $7 \mathrm{C}$ & PERMIAN BASIN & ELLENBURGER & DOLO & WD & 12100.0 & 285.0 & & 23.00 & 53.00 & 17.59 \\
\hline 42383 & BARNHART ELLENBURGER & $7 \mathrm{C}$ & PERMIAN BASIN & ELLENBURGER & DOLO & SG+PWD & 9000.0 & 75.0 & 397 & 7.00 & 47.00 & 16.17 \\
\hline 42461 & BENEDUM SPRABERRY & $7 \mathrm{C}$ & PERMIAN BASIN & SPRABERRY & SS & SG & 7600.0 & 33.0 & 250 & 0.50 & 36.00 & 23.57 \\
\hline 42383 & BIG LAKE & $7 \mathrm{C}$ & PERMIAN BASIN & SAN ANDRES & DOLO & WD & 3000.0 & 30.0 & 160 & 20.00 & 36.00 & 109.27 \\
\hline 42383 & BIG LAKE ELLENBURGER & $7 \mathrm{C}$ & PERMIAN BASIN & ELLENBURGER & DOLO & WD & 8300.0 & & 282 & & 42.00 & 21.17 \\
\hline 42383 & CALVIN DEAN & $7 C$ & PERMIAN BASIN & DEAN & SS & SG & 7400.0 & 35.0 & & 1.00 & 41.00 & 40.98 \\
\hline 42431 & COPE & $7 \mathrm{C}$ & PERMIAN BASIN & SPRABERRY & ss & SG & 5100.0 & 23.0 & & 24.00 & 35.00 & 12.12 \\
\hline$\overline{42399}$ & CREE-SYKES GARDNER & $7 \mathrm{C}$ & BEND ARCH & GARDNER & ss & SG & 4000.0 & 19.0 & & 111.00 & 41.00 & 15.47 \\
\hline 42105 & ELKHORN ELLENBURGER & $7 \mathrm{C}$ & PERMIAN BASIN & ELLENBURGER & DOLO & $W D+S G$ & 7200.0 & 121.0 & 455 & 34.00 & 39.00 & 11.75 \\
\hline
\end{tabular}


Table A1. Texas Reservoir Database (Continued)

\begin{tabular}{|c|c|c|c|c|c|c|c|c|c|c|c|c|}
\hline $\begin{array}{l}\text { CNTY } \\
\text { CODE }\end{array}$ & FIELD_RES & $\begin{array}{l}\text { RRC } \\
\text { DIST }\end{array}$ & PROVINCE & $\begin{array}{l}\text { PRODUCING } \\
\text { FORMATION }\end{array}$ & LITH & DRIVE & DEPTH & $\begin{array}{l}\text { NET } \\
\text { PAY }\end{array}$ & $\begin{array}{c}\text { OlL } \\
\text { COLUMN }\end{array}$ & $\begin{array}{l}\text { AVG. } \\
\text { PERM }\end{array}$ & API & $\begin{array}{l}\text { CUMULATIVE } \\
\text { PRODUCTION }\end{array}$ \\
\hline 42105 & FARMER & $7 \mathrm{C}$ & PERMIAN BASIN & $\begin{array}{l}\text { GRAYBURG-SAN } \\
\text { ANDRES } \\
\end{array}$ & DOLO & SG & 2200.0 & 75.0 & 70 & 4.00 & 30.00 & 18.38 \\
\hline 42399 & FORT CHADBOURNE & 7C & PERMIAN BASIN & STRAWN & LS & SG+PGCE & 5400.0 & 44.0 & 240 & 28.00 & 45.00 & 53.25 \\
\hline 42451 & H-J STRAWN & $7 \mathrm{C}$ & PERMIAN BASIN & STRAWN & LS & SG+PWD & 5500.0 & 50.0 & 200 & 100.00 & 42.00 & 23.20 \\
\hline 42413 & HULLLDALE PENN. REEF & $7 \mathrm{CC}$ & PERMIAN BASIN & $\begin{array}{l}\text { PENNSYLVANIAN } \\
\text { REEF }\end{array}$ & LS & GCE+PWD & 5800.0 & 39.0 & 87 & 43.00 & 40.00 & 26.55 \\
\hline 42081 & I.A.B. MENIELLE PENN. & $7 \mathrm{C}$ & PERMIAN BASIN & MENIELLE & LS & SG & 5800.0 & 75.0 & 435 & 27.00 & 44.00 & 21.50 \\
\hline 42081 & JAMESON & $7 \mathrm{C}$ & PERMIAN BASIN & CISCO SAND & SS & SG & 6300.0 & 40.0 & 700 & 2.00 & 49.00 & 44.85 \\
\hline 42081 & JAMESON REEF & $7 \mathrm{C}$ & PERMIAN BASIN & STRAWN & LS & GCE+SG & 6400.0 & 71.0 & 405 & 2.00 & 43.00 & 41.41 \\
\hline 42461 & MCCAMEY & $7 \mathrm{C}$ & PERMIAN BASIN & $\begin{array}{l}\text { GRAYBURG-SAN } \\
\text { ANDRES }\end{array}$ & DO,SS & SG+PWD & 2200.0 & 75.0 & 260 & 18.00 & 28.00 & 132.84 \\
\hline 42413 & NEVA WEST STRAWN & $7 \mathrm{C}$ & PERMIAN BASIN & STRAWN & LS & GCE & 6200.0 & 80.0 & 166 & 8.00 & 46.00 & 13.90 \\
\hline 42105 & OLSON & $7 \mathrm{C}$ & PERMIAN BASIN & $\begin{array}{l}\text { GRAYBURG-SAN } \\
\text { ANDRES }\end{array}$ & DOLO & SG & 1800.0 & 40.0 & 200 & 28.00 & 25.00 & 14.04 \\
\hline 42461 & PEGASUS ELLENBURGER & $7 \mathrm{C}$ & PERMIAN BASIN & ELLENBURGER & DOLO & GD & 13000.0 & 28.0 & 829 & & 53.00 & 92.32 \\
\hline 42461 & PEGASUS PENN. & $7 \mathrm{C}$ & PERMIAN BASIN & $\begin{array}{l}\text { PENNSYLVANIAN } \\
\text { LIME }\end{array}$ & LS & SG & 10500.0 & 0.0 & 567 & 9.00 & 44.00 & 15.44 \\
\hline 42461 & PEGASUS SPRABERRY & $7 \mathrm{C}$ & PERMIAN BASIN & SPRABERRY & SS & SG & 8300.0 & 30.0 & 160 & 0.10 & 37.00 & 13.76 \\
\hline 42105 & SHANNON SAN ANDRES & $7 \mathrm{C}$ & PERMIAN BASIN & SAN ANDRES & DOLO & SG & 2400.0 & 35.0 & 170 & 24.00 & 26.00 & 11.62 \\
\hline 42329 & SPRABERRY TREND & $7 \mathrm{C}$ & PERMIAN BASIN & SPRABERRY & SS & SG & 6800.0 & 25.0 & & 0.30 & 39.00 & 457.00 \\
\hline 42451 & SUSAN PEAK & $7 \mathrm{C}$ & PERMIAN BASIN & STRAWN & LS & WD & 4700.0 & 43.0 & 113 & 40.00 & 37.00 & 14.64 \\
\hline 42105 & TODD DEEP CRINOIDAL & $7 \mathrm{C}$ & PERMIAN BASIN & CRINOIDAL & LS & SG+PWD & 5800.0 & 115.0 & 450 & 14.00 & 41.00 & 36.47 \\
\hline 42105 & TODD DEEP ELL. & $7 \mathrm{C}$ & PERMIAN BASIN & ELLENBURGER & DOLO & WD+SG & 6000.0 & 155.0 & & 5.00 & 42.00 & 43.97 \\
\hline 42105 & VAUGHN & $7 \mathrm{C}$ & PERMIAN BASIN & $\begin{array}{l}\text { GRAYBURG-SAN } \\
\text { ANDRES }\end{array}$ & DOLO & SG+GCE & 1500.0 & 30.0 & 80 & 10.00 & 28.00 & 12.31 \\
\hline 42461 & WILSHIRE ELLENBURGER & $7 \mathrm{C}$ & PERMIAN BASIN & ELLENBURGER & DOLO & WD & 12200.0 & 212.0 & 616 & 15.00 & 53.00 & 40.86 \\
\hline 42105 & WORLD & $7 \mathrm{C}$ & PERMIAN BASIN & $\begin{array}{l}\text { GRAYBURG-SAN } \\
\text { ANDRES }\end{array}$ & DOLO & WD & 2600.0 & 50.0 & & 8.00 & 27.00 & 43.35 \\
\hline 42371 & ABELL SIL.-MONTOYA & 8 & PERMIAN BASIN & MONTOYA & $\mathrm{DO}, \mathrm{CH}$ & SG & 5000.0 & 45.0 & 272 & & 40.00 & 12.62 \\
\hline 42135 & ANDECTOR ELL. & 8 & PERMIAN BASIN & ELLENBURGER & DOLO & WD & 8500.0 & 410.0 & 817 & 300.00 & 44.00 & 173.28 \\
\hline 42003 & ANDREWS & 8 & PERMIAN BASIN & $\begin{array}{l}\text { PENNSYLVANIAN } \\
\text { LIME }\end{array}$ & LS & SG & 9200.0 & 0.0 & 300 & 31.00 & 40.00 & 14.29 \\
\hline 42003 & ANDREWS NORTH ELL. & 8 & PERMIAN BASIN & ELLENBURGER & DOLO & WD & 12400.0 & 135.0 & & 50.00 & 45.00 & 28.54 \\
\hline 42003 & ANDREWS SOUTH DEV. & 8 & PERMIAN BASIN & DEVONIAN & LS,DO & SG & 10900.0 & & $\therefore$ & 2.00 & 47.00 & 10.20 \\
\hline 42003 & ANDREWS S. WOLFCAMP & 8 & PERMIAN BASIN & WOLFCAMP LIME & LS & SG & 9100.0 & 34.0 & 200 & 11.00 & 40.00 & 14.23 \\
\hline 42003 & ANDREWS WOLFCAMP & 8 & PERMIAN BASIN & WOLFCAMP LIME & LS & SG & 8600.0 & 25.0 & 250 & 18.00 & 38.00 & 20.80 \\
\hline 42371 & APCO-WARNER ELL. & 8 & PERMIAN BASIN & ELLENBURGER & DOLO & WD & 4600.0 & 150.0 & 300 & 0.00 & 40.00 & 12.32 \\
\hline 42495 & ARENOSA STRAWN DETRITUS & 8 & PERMIAN BASIN & STRAWN & $\mathrm{CH}$ & SG & 8500.0 & 24.0 & 600 & 73.00 & 38.00 & 21.12 \\
\hline
\end{tabular}


Table A1. Texas Reservoir Database (Continued)

\begin{tabular}{|c|c|c|c|c|c|c|c|c|c|c|c|c|}
\hline $\begin{array}{l}\text { CNTY } \\
\text { CODE }\end{array}$ & FIELD_RES & $\begin{array}{l}\text { RRC } \\
\text { DIST }\end{array}$ & PROVINCE & $\begin{array}{l}\text { PRODUCING } \\
\text { FORMATION }\end{array}$ & LITH & DRIVE & DEPTH & $\begin{array}{l}\text { NET } \\
\text { PAY }\end{array}$ & $\begin{array}{c}\text { OIL } \\
\text { COLUMN }\end{array}$ & $\begin{array}{l}\text { AVG. } \\
\text { PERM }\end{array}$ & API & $\begin{array}{l}\text { CUMULATIVE } \\
\text { PRODUCTION }\end{array}$ \\
\hline 42003 & BAKKE & 8 & PERMIAN BASIN & $\begin{array}{l}\text { PENNSYLVANIAN } \\
\text { LIME }\end{array}$ & LS & SG & 8900.0 & 23.0 & 500. & 13.00 & 40.00 & 12.14 \\
\hline 42003 & BAKKE DEVONIAN & 8 & PERMIAN BASIN & DEVONIAN & DOLO & WD & 10500.0 & & 150 & 903.00 & 47.00 & 16.45 \\
\hline 42003 & BAKKE ELLENBURGER & 8 & PERMIAN BASIN & ELLENBURGER & DOLO & WD & 12400.0 & 122.0 & & 47.00 & 43.00 & 23.71 \\
\hline 42003 & BAKKE WOLFCAMP & 8 & PERMIAN BASIN & WOLFCAMP LIME & LS & SG & 8500.0 & 35.0 & 200 & 38.00 & 41,00 & 22.34 \\
\hline 42003 & BEDFORD DEVONIAN & 8 & PERMIAN BASIN & DEVONIAN & $\mathrm{CH}, \mathrm{LS}$ & SG+PWD & 8800.0 & 100.0 & 540 & 5.00 & 41.00 & 16.26 \\
\hline 42317 & BREEDLOVE SIL.-DEV. & 8 & PERMIAN BASIN & SILURO-DEVONIAN & DO,LS & WD & 12100.0 & 45.0 & 145 & 50.00 & 41.00 & 28.97 \\
\hline 42103 & C-BAR & 8 & PERMIAN BASIN & SAN ANDRES & DOLO & SG & 3500.0 & 35.0 & 100 & 5.00 & 33.00 & 18.83 \\
\hline 42103 & CORDONA LAKE DEV. & 8 & PERMIAN BASIN & DEVONIAN & LS,CH & SG & 5400.0 & 60.0 & 235 & 15.00 & 40.00 & 25.93 \\
\hline 42135 & COWDEN NORTH & 8 & PERMIAN BASIN & GRAYBURG & DO,SS & SG+GCE & 4300.0 & 125.0 & 800 & 7.00 & 35.00 & 437.07 \\
\hline 42135 & COWDEN NORTH DEEP & 8 & PERMIAN BASIN & SAN ANDRES & DOLO & SG & 5100.0 & 40.0 & 100 & 7.00 & 37.00 & 52.17 \\
\hline 42135 & COWDEN SOUTH & 8 & PERMIAN BASIN & GRAYBURG & DOLO & SG & 4600.0 & 56.0 & 800 & 3.00 & 35.00 & 147.40 \\
\hline 42135 & COWDEN S. 8790 CANYON & 8 & PERMIAN BASIN & CANYON LIME & LS & SG+LGCE & 8800.0 & 65.0 & 300 & 4.00 & 40.00 & 33.88 \\
\hline 42103 & CROSSETT DEV. & 8 & PERMIAN BASIN & DEVONIAN & $\mathrm{LS}, \mathrm{CH}$ & SG & 5400.0 & 88.0 & 260 & 6.00 & 44.00 & 19.80 \\
\hline 42461 & CROSSETT SOUTH DEV. & 8 & PERMIAN BASIN & DEVONIAN & $\mathrm{DO}, \mathrm{CH}$ & SG & 5600.0 & 80.0 & 500 & 3.00 & 42.00 & 17.15 \\
\hline 42003 & DEEP ROCK ELL. & 8 & PERMIAN BASIN & ELLENBURGER & DOLO & WD & 12300.0 & 146.0 & & 10.00 & 44.00 & 14.01 \\
\hline 42003 & DOLLARHIDE CLEAR FORK & 8 & PERMIAN BASIN & CLEAR FORK & DOLO & SG & 6500.0 & 40.0 & 350 & 10.00 & 38.00 & 35.97 \\
\hline 42003 & DOLLARHIDE DEVONIAN & 8 & PERMIAN BASIN & DEVONIAN & $\mathrm{DO}, \mathrm{CH}$ & SG & 8000.0 & 70.0 & 1000 & 17.00 & 40.00 & 81.25 \\
\hline 42003 & DOLLARHIDE ELL. & 8 & PERMIAN BASIN & ELLENBURGER & DOLO & WD & 10000.0 & 187.0 & & 5.00 & 41.00 & 25.69 \\
\hline 42003 & DOLLARHIDE SILURIAN & 8 & PERMIAN BASIN & SILURIAN & $D O, L S$ & WD & 8500.0 & 194.0 & 520 & 9.00 & 42.00 & 38.83 \\
\hline 42135 & DORA ROBERTS ELL. & 8 & PERMIAN BASIN & ELLENBURGER & DOLO & $S G+W D$ & 13000.0 & 212.0 & & 280.00 & 51.00 & 50.02 \\
\hline 42103 & DUNE & 8 & PERMIAN BASIN & GRAYBURG & DOLO & SG & 3300.0 & 80.0 & 800 & 6.00 & 34.00 & 176.00 \\
\hline 42135 & EDWARDS WEST CANYON & 8 & PERMIAN BASIN & CANYON LIME & LS & SG+LWD & 8700.0 & 80.0 & 300 & 5.00 & 41.00 & 22.77 \\
\hline 42301 & EL MAR DELAWARE & 8 & PERMIAN BASIN & DELAWARE SAND & SS & SG & 4500.0 & 15.0 & & 14.00 & 41.00 & 17.84 \\
\hline 42003 & EMBAR ELLENBURGER & 8 & PERMIAN BASIN & ELLENBURGER & DOLO & WD & 7700.0 & 195.0 & 380 & 40.00 & 45.00 & 22.34 \\
\hline 42003 & EMMA & 8 & PERMIAN BASIN & SAN ANDRES & DOLO & SG & 4000.0 & 58.0 & 183 & 11.00 & 33.00 & 20.09 \\
\hline 42003 & EMMA ELLENBURGER & 8 & PERMIAN BASIN & ELLENBURGER & DOLO & WD & 12300.0 & 290.0 & 183 & 54.00 & 49.00 & 53.73 \\
\hline 42495 & EMPEROR DEEP & 8 & PERMIAN BASIN & $\begin{array}{l}\text { UPPER } \\
\text { GUADALUPIAN }\end{array}$ & SS,DO & SG & 2900.0 & 61.0 & 350 & 20.00 & 33.00 & 11.18 \\
\hline 42371 & FORT STOCKTON & 8 & PERMIAN BASIN & $\begin{array}{l}\text { UPPER } \\
\text { GUADALUPIAN }\end{array}$ & SS & SG+LGCE & 2800.0 & 38.0 & 450 & 35.00 & 32.00 & 30.89 \\
\hline 42135 & FOSTER & 8 & PERMIAN BASIN & GRAYBURG & DOLO & SG & 4300.0 & 110.0 & 800 & 7.00 & 35.00 & 256.88 \\
\hline 42003 & FUHRMAN-MASCHO & 8 & PERMIAN BASIN & $\begin{array}{l}\text { GRAYBURG-SAN } \\
\text { ANDRES } \\
\end{array}$ & DOLO & $S G+W D$ & 4300.0 & 72.0 & 295 & 5.00 & 32.00 & 104.48 \\
\hline 42003 & FULLERTON & 8 & PERMIAN BASIN & CLEAR FORK & 00, LS & SG & 7000.0 & & 500 & 3.00 & 42.00 & 262.21 \\
\hline 42003 & FULLERTON 8500 DEV. & 8 & PERMIAN BASIN & DEVONIAN & DOLO & WD & 8500.0 & 40.0 & 350 & 50.00 & 45.00 & 46.02 \\
\hline 42003 & FULLERTON SOUTH ELL. & 8 & PERMIAN BASIN & ELLENBURGER & DOLO & WD & 10700.0 & 275.0 & & 77.00 & 44.00 & 11.82 \\
\hline
\end{tabular}


Table A1. Texas Reservoir Database (Continued)

\begin{tabular}{|c|c|c|c|c|c|c|c|c|c|c|c|c|}
\hline $\begin{array}{l}\text { CNTY } \\
\text { CODE }\end{array}$ & FIELD_RES & $\begin{array}{l}\text { RRC } \\
\text { DIST }\end{array}$ & PROVINCE & $\begin{array}{l}\text { PRODUCING } \\
\text { FORMATION }\end{array}$ & LITH & DRIVE & DEPTH & $\begin{array}{l}\text { NET } \\
\text { PAY }\end{array}$ & $\begin{array}{c}\text { OlL } \\
\text { COLUMN }\end{array}$ & $\begin{array}{l}\text { AVG. } \\
\text { PERM }\end{array}$ & API & $\begin{array}{l}\text { CUMULATIVE } \\
\text { PRODUCTION }\end{array}$ \\
\hline 42389 & GERALDINE-FORD & 8 & PERMIAN BASIN & CHERRY CANYON & ss & SG & 2600.0 & 28.0 & 400 & 49.00 & 41.00 & 21.73 \\
\hline 42003 & GLASCO DEVONIAN & 8 & PERMIAN BASIN & DEVONIAN & DOLO & WD & 12600.0 & 67.0 & 150 & 200.00 & 37.00 & 19.99 \\
\hline 42135 & GOLDSMITH & 8 & PERMIAN BASIN & SAN ANDRES & DOLO & SG+GCE & 4100.0 & 48.0 & 300 & 12.00 & 36.00 & 345.85 \\
\hline 42135 & GOLDSMITH 5600 & 8 & PERMIAN BASIN & CLEAR FORK & DOLO & SG & 5600.0 & 50.0 & 400 & 25.00 & 38.00 & 223.85 \\
\hline 42135 & GOLDSMITH CLEAR FORK & 8 & PERMIAN BASIN & CLEAR FORK & $D O, L S$ & SG & 6100.0 & 70.0 & 200 & 5.00 & 40.00 & 73.30 \\
\hline 42135 & GOLDSMITH DEVONIAN & 8 & PERMIAN BASIN & DEVONIAN & LS.CH & SG+PWD & 8000.0 & 45.0 & 150 & 47.00 & 40.00 & 13.93 \\
\hline 42135 & GOLDSMITH NORTH & 8 & PERMIAN BASIN & SAN ANDRES & DOLO & SG & 4400.0 & 35.0 & 200 & 2.00 & 35.00 & 16.46 \\
\hline 42495 & HALLEY & 8 & PERMIAN BASIN & $\begin{array}{l}\text { YATES-SEVEN } \\
\text { RIVERS } \\
\end{array}$ & $S S, D O$ & COMBINED & 2700.0 & 45.0 & 300 & 20.00 & 34.00 & 42.43 \\
\hline 42135 & HARPER & 8 & PERMIAN BASIN & $\begin{array}{l}\text { GRAYBURG-SAN } \\
\text { ANDRES }\end{array}$ & DOLO & SG & 4100.0 & 50.0 & 400 & 2.00 & 36.00 & 45.55 \\
\hline 42135 & HARPER ELLENBURGER & 8 & PERMIAN BASIN & ELLENBURGER & DO,LS & $S G+W D$ & 12300.0 & 225.0 & & 2.00 & 46.00 & 22.46 \\
\hline 42135 & HEADLEE ELLENBURGER & 8 & PERMIAN BASIN & ELLENBURGER & DOLO & SG+PWD & 13300.0 & 325.0 & 393 & 40.00 & 51.00 & 37.68 \\
\hline 42495 & HENDERSON & 8 & PERMIAN BASIN & $\begin{array}{l}\text { UPPER } \\
\text { GUADALUPIAN } \\
\end{array}$ & Do,ss & SG+LWD & 3100.0 & 40.0 & 200 & 50.00 & 31.00 & 15.88 \\
\hline 42495 & HENDRICK & 8 & PERMIAN BASIN & $\begin{array}{l}\text { UPPER } \\
\text { GUADALUPIAN } \\
\text { REEF }\end{array}$ & SS,DO & WD & 2500.0 & 100.0 & 750 & 7.00 & 28.00 & 260.45 \\
\hline 42227 & HOWARD-GLASSCOCK GLOR. & 8 & PERMIAN BASIN & GLORIETA & LS,DO & $S G+W D$ & 3200.0 & 60.0 & & 4.00 & 27.00 & 87.20 \\
\hline 42227 & HOWARD-GLASSCOCK PERM. & 8 & PERMIAN BASIN & PERMIAN LIME & Do,ss & SG & 1500.0 & 147.0 & & 25.00 & 32.00 & 310.64 \\
\hline 42003 & HUTEX DEVONIAN & 8 & PERMIAN BASIN & DEVONIAN & $D O, L S$ & WD & 12500.0 & 60.0 & 270 & 44.00 & 44.00 & 44.31 \\
\hline 42227 & IATAN-EAST HOWARD & 8 & PERMIAN BASIN & $\begin{array}{l}\text { GRAYBURG-SAN } \\
\text { ANDRES }\end{array}$ & DO,ss & SG+PWD & 2700.0 & 65.0 & 500 & 10.00 & 30.00 & 143.08 \\
\hline 42003 & INEZ ELLENBURGER & 8 & PERMIAN BASIN & ELLENBURGER & DOLO & WD & 12500.0 & 50.0 & & 9.00 & 50.00 & 16.40 \\
\hline 42135 & JOHNSON & 8 & PERMIAN BASIN & $\begin{array}{l}\text { GRAYBURG-SAN } \\
\text { ANDRES }\end{array}$ & $D O, L S$ & SG & 4100.0 & & 200 & 5.00 & 35.00 & 29.96 \\
\hline 42103 & JORDAN & 8 & PERMIAN BASIN & $\begin{array}{l}\text { GRAYBURG-SAN } \\
\text { ANDRES }\end{array}$ & DOLO & SG & 3500.0 & & 300 & 20.00 & 35.00 & 84.62 \\
\hline 42135 & JORDAN ELLENBURGER & 8 & PERMIAN BASIN & ELLENBURGER & DOLO & WD & 8800.0 & & & 300.00 & 45.00 & 31.11 \\
\hline 42495 & KERMIT & 8 & PERMIAN BASIN & $\begin{array}{l}\text { UPPER } \\
\text { GUADALUPIAN }\end{array}$ & $S S, D O$ & SG & 2800.0 & 22.0 & 600 & 14.00 & 34.00 & 107.91 \\
\hline 42495 & KEYSTONE COLBY & 8 & PERMIAN BASIN & COLBY & SS,DO & SG & 3100.0 & 900.0 & 550 & 3.00 & 38.00 & 71.70 \\
\hline 42495 & KEYSTONE DEV. & 8 & PERMIAN BASIN & DEVONIAN & $\mathrm{CH}, \mathrm{LS}$ & SG+PGCE & 7900.0 & 60.0 & 1100 & 8.00 & 37.00 & 15.34 \\
\hline 42495 & KEYSTONE ELLENBURGER & 8 & PERMIAN BASIN & ELLENBURGER & DOLO & WD+PGCE & 9600.0 & 300.0 & 585 & 5.00 & 44.00 & 144.90 \\
\hline 42495 & KEYSTONE HOLT & 8 & PERMIAN BASIN & SAN ANDRES & DO,LS & SG & 4800.0 & 55.0 & 55 & 58.00 & 40.00 & 39.70 \\
\hline 42495 & KEYSTONE SIL. & 8 & PERMIAN BASIN & SILURIAN LIME & DO.LS & SG & 8400.0 & 113.0 & 1200 & 3.00 & 39.00 & 28.88 \\
\hline 42135 & LAWSON & 8 & PERMIAN BASIN & SAN ANDRES & DOLO & SG+PWD & 4300.0 & 36.0 & 100 & 6.00 & 37.00 & 15.33 \\
\hline 42103 & LEA ELLENBURGER & 8 & PERMIAN BASIN & ELLENBURGER & DOLO & WD & 8200.0 & 202.0 & 430 & 300.00 & 43.00 & 20.11 \\
\hline
\end{tabular}




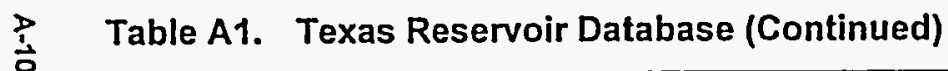

\begin{tabular}{|c|c|c|c|c|c|c|c|c|c|c|c|c|}
\hline $\begin{array}{l}\text { CNTY } \\
\text { CODE }\end{array}$ & FIELD_RES & $\begin{array}{l}\text { RRC } \\
\text { DIST }\end{array}$ & PROVINCE & $\begin{array}{l}\text { PRODUCING } \\
\text { FORMATION }\end{array}$ & LITH & DRIVE & DEPTH & \begin{tabular}{|l|} 
NET \\
PAY
\end{tabular} & $\begin{array}{c}\text { OIL } \\
\text { COLUMN }\end{array}$ & $\begin{array}{l}\text { AVG. } \\
\text { PERM }\end{array}$ & API & $\begin{array}{l}\text { CUMULATIVE } \\
\text { PRODUCTION }\end{array}$ \\
\hline 42003 & LOWE ELLENBURGER & 8 & PERMIAN BASIN & ELLENBURGER & DOLO & WD & 13300.0 & 120.0 & & 31.00 & 54.00 & 11.61 \\
\hline 42003 & LOWE SILURIAN & 8 & PERMIAN BASIN & SILURIAN & DOLO & SG & 12800.0 & 50.0 & 150 & 7.00 & 49.00 & 14.41 \\
\hline 42227 & LUTHER S.E. SIL.-DEV. & 8 & PERMIAN BASIN & SILURO-DEVONIAN & DOLO & $S G$ & 9900.0 & 65.0 & 125 & 16.00 & 44.00 & 23.89 \\
\hline 42003 & MABEE & 8 & PERMIAN BASIN & SAN ANDRES & DOLO & $S G$ & 4700.0 & 40.0 & 150 & 8.00 & 32.00 & 89.56 \\
\hline 42003 & MABEE & 8 & PERMIAN BASIN & SAN ANDRES & DOLO & SG & 4700.0 & 40.0 & 150 & 8.00 & 32.00 & 89.56 \\
\hline 42003 & MAGUTEX DEVONIAN & 8 & PERMIAN BASIN & DEVONIAN & $D O, L S$ & WD & 12500.0 & & 150 & 83.00 & 43.00 & 45.43 \\
\hline 42003 & MAGUTEX ELLENBURGER & 8 & PERMIAN BASIN & ELLENBURGER & $L S, D O$ & WD & 13800.0 & 70.0 & 160 & 16.00 & 46.00 & 17.23 \\
\hline 42003 & MARTIN ELLENBURGER & 8 & PERMIAN BASIN & ELLENBURGER & DOLO & WD & 8800.0 & 278.0 & 545 & 369.00 & 43.00 & 36.40 \\
\hline 42103 & MCELROY & 8 & PERMIAN BASIN & $\begin{array}{l}\text { GRAYBURG-SAN } \\
\text { ANDRES }\end{array}$ & DOLO & SG & 2900.0 & 86.0 & 1400 & 50.00 & 32.00 & 483.43 \\
\hline 42003 & MCFARLAND & 8 & PERMIAN BASIN & QUEEN & SS,DO & SG & 4800.0 & 17.0 & 325 & 12.00 & 34.00 & 38.60 \\
\hline 42003 & MEANS 1 & 8 & PERMIAN BASIN & $\begin{array}{l}\text { GRAYBURG-SAN } \\
\text { ANDRES }\end{array}$ & DO,SS & WD+GCE & 4400.0 & 135.0 & 230 & 20.00 & 31.00 & 180.36 \\
\hline 42003 & MEANS 2 & 8 & PERMIAN BASIN & QUEEN & ss & SG & 4100.0 & 7.0 & 250 & 40.00 & 33.00 & 37.56 \\
\hline 42003 & MIDLAND FARMS & 8 & PERMIAN BASIN & $\begin{array}{l}\text { GRAYBURG-SAN } \\
\text { ANDRES } \\
\end{array}$ & DOLO & SG+PWD & 4800.0 & 100.0 & 250 & 61.00 & 32.00 & 144.62 \\
\hline 42003 & MIDLAND FARMS ELL. & 8 & PERMIAN BASIN & ELLENBURGER & DOLO & WD & 12600.0 & & 525 & 9.00 & 48.00 & 50.01 \\
\hline 42003 & MIDLAND FARMS NORTH & 8 & PERMIAN BASIN & $\begin{array}{l}\text { GRAYBURG-SAN } \\
\text { ANDRES }\end{array}$ & DOLO & SG+PWD & 4800.0 & 51.0 & 200 & 6.00 & 29.00 & 15.68 \\
\hline 42003 & MIDLAND FARMS WOLFCAMP & 8 & PERMIAN BASIN & WOLFCAMP LIME & LS & SG & 8400.0 & 20.0 & 300 & 30.00 & 41.00 & 13.65 \\
\hline 42003 & NOLLEY WOLFCAMP & 8 & PERMIAN BASIN & WOLFCAMP LIME & LS,DO & SG+PWD & 9100.0 & 60.0 & 400 & 20.00 & 37.00 & 26.84 \\
\hline 42227 & OCEANIC & 8 & PERMIAN BASIN & $\begin{array}{l}\text { PENNSYLVANIAN } \\
\text { REEF }\end{array}$ & LS & WD & 8100.0 & 60.0 & 215 & 84.00 & 42.00 & 22.71 \\
\hline 42371 & PAYTON & 8 & PERMIAN BASIN & YATES & ss & SG & 2000.0 & 20.0 & & 35.00 & 36.00 & 13.00 \\
\hline 42371 & PECOS VALLEY HI GRAV. & 8 & PERMIAN BASIN & YATES & ss & $S G$ & 1700.0 & 16.0 & 400 & 45.00 & 31.00 & 19.05 \\
\hline 42135 & PENWELLL & 8 & PERMIAN BASIN & $\begin{array}{l}\text { GRAYBURG-SAN } \\
\text { ANDRES }\end{array}$ & DOLO & SG & 3600.0 & & 400 & 3.00 & 33.00 & 83.23 \\
\hline 42135 & PENWELL ELLENBURGER & 8 & PERMIAN BASIN & ELLENBURGER & DOLO & WD & 8900.0 & 85.0 & & & 43.00 & 13.91 \\
\hline 42103 & RUNNING W WADDELL & 8 & PERMIAN BASIN & WADDELL & ss & SG+GCE & 6100.0 & 22.0 & 350 & 164.00 & 38.00 & 23.73 \\
\hline 42103 & SAND HILLS MCKNIGHT & 8 & PERMIAN BASIN & SAN ANDRES & DOLO & $S G+G C E$ & 3500.0 & 150.0 & 500 & 1.00 & 33.00 & 115.40 \\
\hline 42103 & SAND HILLS ORD. & 8 & PERMIAN BASIN & ORDOVICIAN & DOLO & WD & 5900.0 & 20.0 & 30 & 0.00 & 37.00 & 12.66 \\
\hline 42103 & SAND HILLS TUBB & 8 & PERMIAN BASIN & TUBB & DOLO & SG+PGCE & 4500.0 & 47.0 & 250 & 30.00 & 35.00 & 90.41 \\
\hline 42495 & SCARBOROUGH & 8 & PERMIAN BASIN & YATES & ss & SG+LWD & 3000.0 & 55.0 & 450 & 12.00 & 37.00 & 36.68 \\
\hline 42003 & SHAFTER LAKE DEV. & 8 & PERMIAN BASIN & DEVONIAN & LS & $S G+P G D$ & 9500.0 & 140.0 & 710 & 6.00 & 38.00 & 24.48 \\
\hline 42003 & SHAFTER LAKE SAN AND. & 8 & PERMIAN BASIN & SAN ANDRES & DOLO & $S G$ & 4400.0 & 37.0 & 400 & 5.00 & 34.00 & 42.80 \\
\hline 42003 & SHAFTER LAKE WOLFCAMP & 8 & PERMIAN BASIN & WOLFCAMP LIME & LS & SG & 8400.0 & 18.0 & 235 & 28.00 & 42.00 & 12.16 \\
\hline 42475 & SHIPLEY & 8 & PERMIAN BASIN & QUEEN & SS.DO & SG+PWD & 2400.0 & 0.0 & 150 & 22.00 & 35.00 & 28.44 \\
\hline
\end{tabular}


Table A1. Texas Reservoir Database (Continued)

\begin{tabular}{|c|c|c|c|c|c|c|c|c|c|c|c|c|}
\hline $\begin{array}{l}\text { CNTY } \\
\text { CODE }\end{array}$ & FIELD_RES & $\begin{array}{l}\text { RRC } \\
\text { DIST }\end{array}$ & PROVINCE & $\begin{array}{l}\text { PRODUCING } \\
\text { FORMATION } \\
\end{array}$ & LITH & DRIVE & DEPTH & $\begin{array}{l}\text { NET } \\
\text { PAY }\end{array}$ & $\begin{array}{c}\text { OIL } \\
\text { COLUMN }\end{array}$ & $\begin{array}{l}\text { AVG. } \\
\text { PERM }\end{array}$ & API & $\begin{array}{l}\text { CUMULATIVE } \\
\text { PRODUCTION } \\
\end{array}$ \\
\hline 42227 & SNYDER & 8 & PERMIAN BASIN & SAN ANGELOO & DOLO & SG & 2600.0 & 50.0 & & 1.00 & 30.00 & 38.73 \\
\hline 42371 & TAYLOR-LINK & 8 & PERMIAN BASIN & SAN ANDRES & $S S, L S$ & $S G+W D$ & 1300.0 & 35.0 & 90 & 40.00 & 32.00 & 15.30 \\
\hline 42003 & THREE BAR DEV. & 8 & PERMIAN BASIN & DEVONIAN & CH,LS & SG & 8400.0 & & 375 & 54.00 & 40.00 & 39.04 \\
\hline 42371 & TOBORG CRETACEOUS & 8 & PERMIAN BASIN & CRETACEOUS & ss & SG & 500.0 & & & 86.00 & 22.00 & 41.23 \\
\hline 42003 & TRIPLE-N PENN. & 8 & PERMIAN BASIN & $\begin{array}{l}\text { UPPER } \\
\text { PENNSYLVANIAN } \\
\text { LIME }\end{array}$ & LS & $S G$ & 8900.0 & & 300 & 7.00 & 40.00 & 15.43 \\
\hline 42389 & TUNSTILL & 8 & PERMIAN BASIN & DELAWARE SAND & ss & SG & 3300.0 & 12.0 & 215 & 30.00 & 40.00 & 11.51 \\
\hline 42301 & TWOFREDS DELAWARE & 8 & PERMIAN BASIN & DELAWARE SAND & ss & SG & 4900.0 & 21.0 & 210 & 33.00 & 35.00 & 12.72 \\
\hline 42135 & TXL DEV. & 8 & PERMIAN BASIN & DEVONIAN & $\mathrm{CH}$ & SG & 8000.0 & & 600 & 100.00 & 40.00 & 43.51 \\
\hline 42135 & TXL ELLENBURGER & 8 & PERMIAN BASIN & ELLENBURGER & DOLO & WD & 9600.0 & 240.0 & 660 & 39.00 & 44.00 & 128.30 \\
\hline 42135 & TXL TUBB & 8 & PERMIAN BASIN & CLEAR FORK & DOLO & SG & 6200.0 & & 450 & 1.00 & 35.00 & 43.04 \\
\hline 42003 & UNION & 8 & PERMIAN BASIN & $\begin{array}{l}\text { LOWER CLEAR } \\
\text { FORK }\end{array}$ & DOLO & SG & 6900.0 & 55.0 & 200 & 2.00 & 33.00 & 15.90 \\
\hline 42103 & UNIV. BLOCK 31 DEVONIAN & 8 & PERMIAN BASIN & DEVONIAN & $\mathrm{LS}, \mathrm{CH}$ & SG & 8500.0 & 130.0 & 610 & 0.70 & 40.00 & 206.62 \\
\hline 42003 & UNIV. BLOCK 9 DEV. & 8 & PERMIAN BASIN & DEVONIAN & DOLO & WD & 10500.0 & 107.0 & 400 & 3.00 & 45.00 & 20.07 \\
\hline 42003 & UNIV. BLOCK 9 PENN. & 8 & PERMIAN BASIN & $\begin{array}{l}\text { PENNSYLVANIAN } \\
\text { LIME }\end{array}$ & LS & $S G$ & 9000.0 & 35.0 & 250 & 11.00 & 40.00 & 12.66 \\
\hline 42003 & UNIV. BLOCK 9 WOLFCAMP & 8 & PERMIAN BASIN & WOLFCAMP LIME & LS & SG & 8400.0 & 40.0 & 250 & 14.00 & 38.00 & 25.62 \\
\hline 42103 & UNIV. WADDELL DEV. & 8 & PERMIAN BASIN & DEVONIAN & LS.CH & SG & 8600.0 & & 900 & 1.00 & 40.00 & 61.07 \\
\hline 42227 & VEALMOOR & 8 & PERMIAN BASIN & CANYON REEF & LS & WD & 7800.0 & 95.0 & 200 & 32.00 & 46.00 & 37.52 \\
\hline 42033 & VEALMOOR EAST & 8 & PERMIAN BASIN & CANYON REEF & LS & WD & 7400.0 & 107.0 & 610 & 38.00 & 48.00 & 59.98 \\
\hline 42329 & VIREY ELLENBURGER & 8 & PERMIAN BASIN & ELLENBURGER & DOLO & $S G+W D$ & 13100.0 & 153.0 & 0 & 32.00 & 51.00 & 30.08 \\
\hline 42103 & WADDELL & 8 & PERMIAN BASIN & $\begin{array}{l}\text { GRAYBURG-SAN } \\
\text { ANDRES }\end{array}$ & DOLO & SG & 3500.0 & 100.0 & 300 & 12.00 & 34.00 & 99.33 \\
\hline 42475 & WARD SOUTH & 8 & PERMIAN BASIN & $\begin{array}{l}\text { UPPER } \\
\text { GUADALUPIAN } \\
\end{array}$ & SS,DO & SG & 2400.0 & 18.0 & 350 & 40.00 & 35.00 & 104.13 \\
\hline 42475 & WARD-ESTES NORTH & 8 & PERMIAN BASIN & $\begin{array}{l}\text { UPPER } \\
\text { GUADALUPIAN }\end{array}$ & SS,DO & COMBINED & 2500.0 & 30.0 & 600 & 40.00 & 38.00 & 366.69 \\
\hline 42329 & WAR-SAN ELLENBURGER & 8 & PERMIAN BASIN & ELLENBURGER & DOLO & SG+PWD & 13100.0 & 150.0 & & 51.00 & 49.00 & 14.27 \\
\hline 42335 & WESTBROOK & 8 & PERMIAN BASIN & CLEAR FORK & DOLO & SG & 2900.0 & 45.0 & 250 & 5.00 & 24.00 & 90.74 \\
\hline 42301 & WHEAT & 8 & PERMIAN BASIN & DELAWARE SAND & ss & SG & 4300.0 & 17.0 & 230 & 19.00 & 36.00 & 21.80 \\
\hline 42495 & WHEELER ELLENBURGER & 8 & PERMIAN BASIN & ELLENBURGER & DOLO & $W D$ & 10500.0 & 88.0 & 342 & 54.00 & 44.00 & 17.85 \\
\hline 42135 & YAR. AND ALLEN ELL. & 8 & PERMIAN BASIN & ELLENBURGER & DOLO & WD & 10500.0 & 24.0 & & 28.00 & 41.00 & 40.13 \\
\hline 42371 & YATES PERM. GUAD. & 8 & PERMIAN BASIN & $\begin{array}{l}\text { PERMIAN } \\
\text { GUADALUPIAN }\end{array}$ & DO,LS & GD+GCE & 1250.0 & 120.0 & 486 & 118.00 & 30.00 & 1180.07 \\
\hline 42317 & ACKERLY DEAN & $8 \mathrm{~A}$ & PERMIAN BASIN & DEAN & SS & $S G$ & 8200.0 & 35.0 & 500 & 0.40 & 38.00 & 33.35 \\
\hline 42445 & ADAIR & $8 \mathrm{~A}$ & PERMIAN BASIN & SAN ANDRES & DOLO & SG & 4800.0 & 60.0 & 140 & 4.00 & 34.00 & 56.61 \\
\hline
\end{tabular}




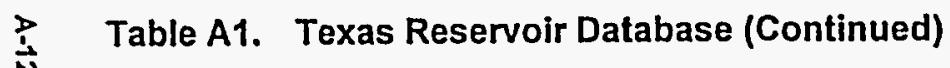

\begin{tabular}{|c|c|c|c|c|c|c|c|c|c|c|c|c|}
\hline $\begin{array}{l}\text { CNTY } \\
\text { CODE }\end{array}$ & FIELD_RES & $\begin{array}{l}\text { RRC } \\
\text { DIST }\end{array}$ & PROVINCE & $\begin{array}{l}\text { PRODUCING } \\
\text { FORMATION }\end{array}$ & LITH & DRIVE & DEPTH & $\begin{array}{l}\text { NET } \\
\text { PAY }\end{array}$ & $\begin{array}{c}\text { OIL } \\
\text { COLUMN }\end{array}$ & $\begin{array}{l}\text { AVG. } \\
\text { PERM }\end{array}$ & API & $\begin{array}{l}\text { CUMULATIVE } \\
\text { PRODUCTION }\end{array}$ \\
\hline 42445 & ADAIR WOLFCAMP & $8 \mathrm{~A}$ & PERMIAN BASIN & WOLFCAMP & LS & SG & 8500.0 & 68.0 & 215 & 28.00 & 43.00 & 51.48 \\
\hline 42165 & AMROW DEVONIAN & $8 \mathrm{~A}$ & PERMIAN BASIN & DEVONIAN & DOLO & WD & 12600.0 & 131.0 & 159 & 34.00 & 35.00 & 14.89 \\
\hline 42279 & ANTON-IRISH & $8 \mathrm{~A}$ & PERMIAN BASIN & CLEAR FORK & DOLO & SG & 5300.0 & 141.0 & $\cdot 700$ & 9.00 & 31.00 & 175.24 \\
\hline 42501 & BRAHANEY & $8 \mathrm{~A}$ & PERMIAN BASIN & SAN ANDRES & DOLO & SG & 5200.0 & 35.0 & 179 & 2.00 & 32.00 & 43.00 \\
\hline 42501 & BRONCO SIL.-DEV. & $8 \mathrm{~A}$ & PERMIAN BASIN & SILURO-DEVONIAN & DOLO & WD & 11800.0 & 160.0 & 265 & 150.00 & 44.00 & 13.97 \\
\hline 42165 & CEDAR LAKE & $8 \mathrm{~A}$ & PERMIAN BASIN & SAN ANDRES & DO,LS & SG & 4800.0 & 50.0 & 250 & 12.00 & 33.00 & 78.60 \\
\hline 42263 & CLAIREMONT & $8 \mathrm{~A}$ & PERMIAN BASIN & $\begin{array}{l}\text { LOWER } \\
\text { PENNSYLVANIAN }\end{array}$ & LS & WD & 6700.0 & 20.0 & 47 & 21.00 & 39.00 & 15.27 \\
\hline 42263 & COGDELL & $8 \mathrm{~A}$ & PERMIAN BASIN & CANYON REEF & LS & SG & 6800.0 & 73.0 & 770 & 18.00 & 42.00 & 256.48 \\
\hline 42415 & DIAMOND M & $8 \mathrm{~A}$ & PERMIAN BASIN & CANYON REEF & LS & SG+PWD & 6600.0 & 80.0 & 440 & 72.00 & 44.00 & 237.59 \\
\hline 42169 & DORWARD & $8 \mathrm{~A}$ & PERMIAN BASIN & SAN ANGELO & DOLO & SG & 2400.0 & 45.0 & 100 & 3.00 & 38.00 & 18.25 \\
\hline 42165 & FLANAGAN U. CLFK. & $8 \mathrm{~A}$ & PERMIAN BASIN & $\begin{array}{l}\text { UPPER CLEAR } \\
\text { FORK }\end{array}$ & DOLO & SG & 6300.0 & 45.0 & 750 & 3.00 & 32.00 & 20.85 \\
\hline 42415 & FLUVANNA STRAWN & $8 \mathrm{~A}$ & PERMIAN BASIN & STRAWN & LS & SG+PWD & 7800.0 & 42.0 & 300 & 93.00 & 40.00 & 13.63 \\
\hline 42169 & GARZA & $8 \mathrm{~A}$ & PERMIAN BASIN & SAN ANDRES & DOLO & SG & 2500.0 & 55.0 & 300 & 8.00 & 35.00 & 95.01 \\
\hline 42033 & GOOD & $8 \mathrm{~A}$ & PERMIAN BASIN & CANYON REEF & LS & WD & 8000.0 & 246.0 & 489 & 52.00 & 44.00 & 47.11 \\
\hline 42165 & HARRIS & $8 \mathrm{~A}$ & GULF COAST BASIN & GLORIETA & Do, SS & SG & 5900.0 & 55.0 & & 11.00 & 31.00 & 61.46 \\
\hline 42033 & HOBO & $8 \mathrm{~A}$ & PERMIAN BASIN & CISCO REEF & LS & WD & 7100.0 & 39.0 & 100 & 32.00 & 46.00 & 12.17 \\
\hline 42033 & JO-MILL SPRABERRY & $8 A$ & PERMIAN BASIN & SPRABERRY & ss & $\underline{S G}$ & 7100.0 & 19.4 & & 3.00 & 39.00 & 81.94 \\
\hline 42415 & KELLYYSNYDER & $8 \mathrm{~A}$ & PERMIAN BASIN & CANYON REEF & LS & SG & 6700.0 & 137.0 & 700 & 19.00 & 42.00 & 1210.99 \\
\hline 42415 & KELLYYSNYDER CISCO SAND & $8 \mathrm{~A}$ & PERMIAN BASIN & CISCO SAND & ss & SG & 6100.0 & 20.0 & 120 & 42.00 & 42.00 & 15.18 \\
\hline 42445 & KINGDOM ABO & $8 \mathrm{~A}$ & PERMIAN BASIN & $A B O$ & DOLO & SG & 7800.0 & 70.0 & 400 & 5.00 & 30.00 & 42.12 \\
\hline 42079 & LEVELLAND & $8 \mathrm{~A}$ & PERMIAN BASIN & SAN ANDRES & $D O, L S$ & SG & 4900.0 & 50.0 & & 2.00 & 30.00 & 493.32 \\
\hline 42501 & OWNBY & $8 \mathrm{~A}$ & PERMIAN BASIN & $\begin{array}{l}\text { UPPER CLEAR } \\
\text { FORK }\end{array}$ & DOLO & SG & 6900.0 & 47.0 & 165 & 4.00 & 31.00 & 15.89 \\
\hline 42501 & PRENTICE & $8 \mathrm{~A}$ & PERMIAN BASIN & GLORIETA & DOLO & SG & 6000.0 & 52.0 & 180 & 12.00 & 28.00 & 47.55 \\
\hline 42501 & PRENTICE 6700 & $8 \mathrm{~A}$ & PERMIAN BASIN & $\begin{array}{l}\text { UPPER CLEAR } \\
\text { FORK }\end{array}$ & DOLO & SG & 6700.0 & 85.0 & 270 & 2.00 & 28.00 & 112.39 \\
\hline 42501 & REEVES & $8 \mathrm{~A}$ & PERMIAN BASIN & SAN ANDRES & DOLO & SG & 5600.0 & 45.0 & 180 & 3.00 & 32.00 & 25.60 \\
\hline 42033 & REINECKE & $8 \mathrm{~A}$ & PERMIAN BASIN & CISCO REEF & LS & SG+PWD & 6800.0 & 65.0 & 304 & 22.00 & 46.00 & 78.17 \\
\hline 42415 & REVILO GLORIETA & $8 \mathrm{~A}$ & PERMIAN BASIN & GLORIETA & DOLO & SG & 2700.0 & 28.0 & & 3.00 & 35.00 & 12.98 \\
\hline 42165 & RILEY N. U. CLFK. & $8 \mathrm{~A}$ & PERMIAN BASIN & $\begin{array}{l}\text { UPPER CLEAR } \\
\text { FORK }\end{array}$ & DOLOO & SG & 6300.0 & 70.0 & 60 & 12.00 & 32.00 & 26.90 \\
\hline 42165 & ROBERTSON N. CLFK. & $8 \mathrm{~A}$ & PERMIAN BASIN & CLEAR FORK & DOLO & $S G$ & 7100.0 & 35.0 & 200 & 19.00 & 35.00 & 122.83 \\
\hline 42165 & RUSSELL 7000 CLFK. & $8 \mathrm{~A}$ & PERMIAN BASIN & CLEAR FORK & DOLO & SG & 7000.0 & 95.0 & 700 & 2.00 & 35.00 & 53.57 \\
\hline 42165 & RUSSELL NORTH DEV. & $8 \mathrm{~A}$ & PERMIAN BASIN & DEVONIAN & DOLO & WD & 11200.0 & 65.0 & 500 & 141.00 & 41.00 & 77.05 \\
\hline 42263 & SALT CREEK & $8 \mathrm{~A}$ & PERMIAN BASIN & ICANYON REEF & LS & SG & 6300.0 & 100.0 & 726 & 10.00 & 40.00 & 260.91 \\
\hline
\end{tabular}


Table A1. Texas Reservoir Database (Continued)

\begin{tabular}{|c|c|c|c|c|c|c|c|c|c|c|c|c|}
\hline $\begin{array}{l}\text { CNTY } \\
\text { CODE }\end{array}$ & FIELD_RES & $\begin{array}{l}\text { RRC } \\
\text { DIST } \\
\end{array}$ & PROVINCE & $\begin{array}{l}\text { PRODUCING } \\
\text { FORMATION }\end{array}$ & LITH & DRIVE & DEPTH & $\begin{array}{l}\text { NET } \\
\text { PAY } \\
\end{array}$ & $\begin{array}{c}\text { OIL } \\
\text { COLUMN }\end{array}$ & $\begin{array}{l}\text { AVG. } \\
\text { PERM }\end{array}$ & API & $\begin{array}{l}\text { CUMULATIVE } \\
\text { PRODUCTION } \\
\end{array}$ \\
\hline 42165 & SEMINOLE & $8 \mathrm{~A}$ & PERMIAN BASIN & SAN ANDRES & DOLO & GCE+SG & 5200.0 & 87.0 & 262 & 25.00 & 35.00 & 458.19 \\
\hline 42165 & SEMINOLE WEST & $8 A$ & PERMIAN BASIN & SAN ANDRES & DOLO & GCE,SG & 5100.0 & 180.0 & 140 & 9.00 & 34.00 & 31.90 \\
\hline 42415 & SHARON RIDGE 1700 & $8 \mathrm{~A}$ & PERMIAN BASIN & $\begin{array}{l}\text { GRAYBURG-SAN } \\
\text { ANDRES }\end{array}$ & DOLO & $S G$ & 1700.0 & 35.0 & & 3.00 & 28.00 & 55.89 \\
\hline 42415 & SHARON RIDGE 2400 & $8 \mathrm{~A}$ & PERMIAN BASIN & SAN ANDRES & DOLO & SG & 2400.0 & 95.0 & 150 & 8.00 & 32.00 & 20.20 \\
\hline 42079 & SLAUGHTER & $8 \mathrm{~A}$ & PERMIAN BASIN & SAN ANDRES & DOLO & SG & 5000.0 & 48.0 & & 11.00 & 30.00 & 857.50 \\
\hline 42263 & S-M-S CANYON SAND & $8 \mathrm{~A}$ & PERMIAN BASIN & CANYON & ss & SG & 6100.0 & 17.0 & 63 & 117.00 & 38.00 & 19.22 \\
\hline 42219 & SMYER & $8 \mathrm{~A}$ & PERMIAN BASIN & CLEAR FORK & DOLO & SG & 5900.0 & 30.0 & 200 & 8.00 & 26.00 & 39.45 \\
\hline 42115 & TEX-HAMON FUSSELMAN & $B A$ & PERMIAN BASIN & FUSSELMAN & $\mathrm{DO}, \mathrm{CH}$ & WD & 11600.0 & 65.0 & 167 & 25.00 & 40.00 & 16.21 \\
\hline 42033 & VON ROEDER AND N.V.R & $8 \mathrm{~A}$ & PERMIAN BASIN & CANYON REEF & LS & SG & 6800.0 & 45.0 & 155 & 13.00 & 43.00 & 30.04 \\
\hline 42501 & WASSON & $8 \mathrm{~A}$ & PERMIAN BASIN & SAN ANDRES & DOLO & $S G+G C E$ & 4900.0 & 275.0 & 330 & 4.00 & 33.00 & 1573.83 \\
\hline 42501 & WASSON 6600 AND 7200 & $8 \mathrm{~A}$ & PERMIAN BASIN & CLEAR FORK & DOLO & SG & 6900.0 & 135.0 & 400 & 10.00 & 33.00 & 107.59 \\
\hline 42501 & WASSON N.E. & $8 \mathrm{~A}$ & PERMIAN BASIN & $\begin{array}{l}\text { LOWER CLEAR } \\
\text { FORK }\end{array}$ & DOLO & SG & 7800.0 & 72.0 & 400 & 9.00 & 30.00 & 13.72 \\
\hline 42115 & WELCH & $8 \mathrm{~A}$ & PERMIAN BASIN & SAN ANDRES & DOLO & SG & 4900.0 & 100.0 & 180 & 9.00 & 33.00 & 141.79 \\
\hline 42445 & WELLMAN - & $8 \mathrm{~A}$ & PERMIAN BASIN & WOLFCAMP REEF & DOLO & SG+PWD & 9300.0 & 338.0 & 800 & 100.00 & 43.00 & 68.04 \\
\hline 42501 & WEST DEVONIAN & $8 \mathrm{~A}$ & PERMIAN BASIN & DEVONIAN & DOLO & WD & 11100.0 & 40.0 & 200 & 9.00 & 40.00 & 22.32 \\
\hline 42077 & ANTELOPE M1 & 9 & $\begin{array}{l}\text { FORT WORTH } \\
\text { SYNCLINE }\end{array}$ & STRAWN & ss & $S G+W D$ & 3200.0 & 18.0 & 65 & 133.00 & 43.00 & 13.76 \\
\hline 42181 & BIG MINERAL CRK. BARNES & 9 & $\begin{array}{l}\text { SOUTH OKLAHOMA } \\
\text { BASIN }\end{array}$ & BARNES & ss & SG & 5300.0 & 54.0 & 300 & 59.00 & 37.00 & 21.08 \\
\hline 42237 & BRYSON EAST & 9 & $\begin{array}{l}\text { FORT WORTH } \\
\text { SYNCLINE }\end{array}$ & STRAWN & ss & SG & 3100.0 & 20.0 & & 60.00 & 40.00 & 14.02 \\
\hline 42487 & FARGO 3900 & 9 & $\begin{array}{l}\text { PALO DURO BASIN } \\
\text { (TEXAS BA) }\end{array}$ & CANYON & ss & SG & 3900.0 & 22.0 & 110 & 100.00 & 41.00 & 12.39 \\
\hline 42487 & FARGO 4200 & 9 & $\begin{array}{l}\text { PALO DURO BASIN } \\
\text { (TEXAS BA) }\end{array}$ & CANYON & ss & SG & 4200.0 & 24.0 & 215 & 10.00 & 40.00 & 12.70 \\
\hline 42097 & GATEWOOD & 9 & PERMIAN BASIN & STRAWN & ss & SG+LWD & 1600.0 & 20.0 & & 148.00 & 33.00 & 11.14 \\
\hline 42337 & HILDRETH & 9 & $\begin{array}{l}\text { FORT WORTH } \\
\text { SYNCLINE }\end{array}$ & BEND & CONGL & $S G+P W D$ & 7500.0 & 15.0 & 100 & 257.00 & 41.00 & 22.55 \\
\hline 42009 & HULL-SILK-SIKES 3800 & 9 & BEND ARCH & STRAWN & ss & SG & 3800.0 & 26.0 & 100 & 180.00 & 39.00 & 20.90 \\
\hline 42009 & HULL-SILK-SIKES 4300 & 9 & BEND ARCH & STRAWN & ss & SG & 4300.0 & & 125 & 61.00 & 41.00 & 50.59 \\
\hline 42077 & JOY STRAWN & 9 & $\begin{array}{l}\text { FORT WORTH } \\
\text { SYNCLINE }\end{array}$ & STRAWN & ss & SG & 4400.0 & 14.0 & 150 & 40.00 & 41.00 & 18.40 \\
\hline 42485 & KMA & 9 & $\begin{array}{l}\text { PALO DURO BASIN } \\
\text { (TEXAS BA) }\end{array}$ & STRAWN & SS,LS & SG & 3700.0 & 24.0 & & 55.00 & 40.00 & 174.27 \\
\hline 42275 & KNOX CITY NORTH CANYON & 9 & PERMIAN BASIN & CANYON & LS & $S G+P W D$ & 4200.0 & & 155 & 13.00 & 40.00 & 15.25 \\
\hline
\end{tabular}


Table A1. Texas Reservoir Database (Continued)

\begin{tabular}{|c|c|c|c|c|c|c|c|c|c|c|c|c|}
\hline $\begin{array}{l}\text { CNTY } \\
\text { CODE }\end{array}$ & FIELD_RES & $\begin{array}{l}\text { RRC } \\
\text { DIST }\end{array}$ & PROVINCE & $\begin{array}{l}\text { PRODUCING } \\
\text { FORMATION }\end{array}$ & LITH & DRIVE & DEPTH & $\begin{array}{l}\text { NET } \\
\text { PAY }\end{array}$ & $\begin{array}{c}\text { OlL } \\
\text { COLUMN }\end{array}$ & $\begin{array}{l}\text { AVG. } \\
\text { PERM }\end{array}$ & API & $\begin{array}{l}\text { CUMULATIVE } \\
\text { PRODUCTION }\end{array}$ \\
\hline 42155 & RASBERRY 6100 & 9 & $\begin{array}{l}\text { PALO DURO BASIN } \\
\text { (TEXAS BA) }\end{array}$ & CADDO LIME & LS & SG & 6100.0 & 47.0 & 174 & 3.00 & 41.00 & 12.37 \\
\hline 42237 & RUSMAG & 9 & BEND ARCH & $\begin{array}{l}\text { CADDO } \\
\text { CONGLOMERATE }\end{array}$ & CONGL & SG+GCE & 4600.0 & 22.0 & 175 & 19.00 & 41.00 & 15.62 \\
\hline 42181 & SADLER PENN. & 9 & $\begin{array}{l}\text { SOUTH OKLAHOMA } \\
\text { FOLDED BELT }\end{array}$ & PENNSYLVANIAN & ss & SG & 6700.0 & 25.0 & 400 & 28.00 & 34.00 & 17.60 \\
\hline 42181 & SANDUSKY OIL CREEK & 9 & $\begin{array}{l}\text { SOUTH OKLAHOMA } \\
\text { FOLDED BELT } \\
\end{array}$ & SIMPSON & ss & SG+PWD & 7200.0 & 33.0 & 80 & 238.00 & 42.00 & 14.84 \\
\hline 42097 & SIVELLS BEND & 9 & $\begin{array}{l}\text { SOUTH OKLAHOMA } \\
\text { FOLDED BELT }\end{array}$ & STRAWN & ss & SG & 6600.0 & 46.0 & & 126.00 & 42.00 & 30.35 \\
\hline 42097 & WALNUT BEND HUDSPETH & 9 & $\begin{array}{l}\text { SOUTH OKLAHOMA } \\
\text { BASIN }\end{array}$ & STRAWN & ss & $S G+L W D$ & 3900.0 & 40.0 & 100 & 138.00 & 40.00 & 21.50 \\
\hline 42097 & WALNUT BEND REGULAR & 9 & $\begin{array}{l}\text { SOUTH OKLAHOMA } \\
\text { BASIN }\end{array}$ & STRAWN & ss & $S G+W D$ & 4900.0 & 50.0 & 300 & 176.00 & 36.00 & 46.34 \\
\hline 42097 & WALNUT BEND WINGER & 9 & $\begin{array}{l}\text { SOUTH OKLAHOMA } \\
\text { BASIN }\end{array}$ & STRAWN & ss & SG+PWD & 5500.0 & 21.0 & 300 & 309.00 & 32.00 & 27.74 \\
\hline 42237 & WORSHAM-STEED BEND & 9 & $\begin{array}{l}\text { FORT WORTH } \\
\text { SYNCLINE }\end{array}$ & $\begin{array}{l}\text { BEND } \\
\text { CONGLOMERATE }\end{array}$ & co,ss & $S G+G C E$ & 4700.0 & 18.0 & 210 & 50.00 & 41.00 & 10.87 \\
\hline
\end{tabular}


Appendix B

API County Codes 


\section{Appendix B}

\section{API County Codes}

\begin{tabular}{|c|c|c|c|}
\hline County Code & County & County Code & County \\
\hline 42001 & Anderson & 42247 & Jim Hogg \\
\hline 42003 & Andrews & 42249 & Jim Weils \\
\hline 42007 & Aransas & 42253 & Jones \\
\hline 42009 & Archer & 42255 & Karnes \\
\hline 42013 & Atascosa & 42263 & Kent \\
\hline 42015 & Austin & 42273 & Kleberg \\
\hline 42025 & Bee & 42275 & Knox \\
\hline 42033 & Borden & 42279 & Lamb \\
\hline 42039 & Brazoria & 42287 & Lee \\
\hline 42041 & Brazos & 42291 & Liberty \\
\hline 42055 & Caldwell & 42293 & Limestone \\
\hline 42057 & Calhoun & 42301 & Loving \\
\hline 42063 & Camp & 42315 & Marion \\
\hline 42065 & Carson & 42317 & Mártin \\
\hline 42067 & Cass & 42321 & Matagorda \\
\hline 42071 & Chambers & 42323 & Maverick \\
\hline 42077 & Clay & 42329 & Midland \\
\hline 42079 & Cochran & 42335 & Mitchell \\
\hline 42081 & Coke & 42337 & Montague \\
\hline 42097 & Cooke & 42339 & Montgomery \\
\hline 42103 & Crane & 42349 & Navarro \\
\hline 42105 & Crockett & 42353 & Nolan \\
\hline 42115 & Dawson & 42355 & Nueces \\
\hline 42123 & Dewitt & 42357 & Ochiltree \\
\hline 42127 & Dimmit & 42365 & Panola \\
\hline 42131 & Duval & 42371 & Pecos \\
\hline 42133 & Eastland & 42373 & Polk \\
\hline 42135 & Ector & 42383 & Reagan \\
\hline 42151 & Fisher & 42389 & Reeves \\
\hline 42155 & Foard & 42391 & Refugio \\
\hline 42157 & Fort Bend & 42399 & Runnels \\
\hline 42159 & Franklin & 42401 & Rusk \\
\hline 42161 & Freestone & 42407 & San Jacinto \\
\hline 42163 & Frio & 42409 & San Patricio \\
\hline 42165 & Gaines & 42413 & Schleicher \\
\hline 42167 & Galveston & 42415 & Scurry \\
\hline 42169 & Garza & 42417 & Shackelford \\
\hline 42175 & Goliad & 42423 & Smith \\
\hline 42181 & Grayson & 42427 & Starr \\
\hline 42187 & Guadalupe & 42429 & Stephens \\
\hline 42199 & Hardin & 42431 & Sterling \\
\hline 42201 & Harris & 42433 & Stonewall \\
\hline 42207 & Haskell & 42445 & Terry \\
\hline 42219 & Hockley & 42449 & Titus \\
\hline 42223 & Hopkins & 42451 & Tom Green \\
\hline 42227 & Howard & 42459 & Upshur \\
\hline 42237 & Jack & 42461 & Upton \\
\hline 42239 & Jackson & 42467 & Van Zandt \\
\hline 42245 & Jefferson & 42469 & Victoria \\
\hline
\end{tabular}


County Code County

42473 Waller

42475 Ward

42479

42481

42485

42487
Webb

Wharton

Wichita

Wilbarger
County Code

42489

42495

42499

42501

42505
County

Willacy

Winkler

Wood

Yoakum

Zapata 
Appendix C

FORTRAN Code Used for Screening 


\section{Appendix C}

\section{FORTRAN Code Used for Screening}

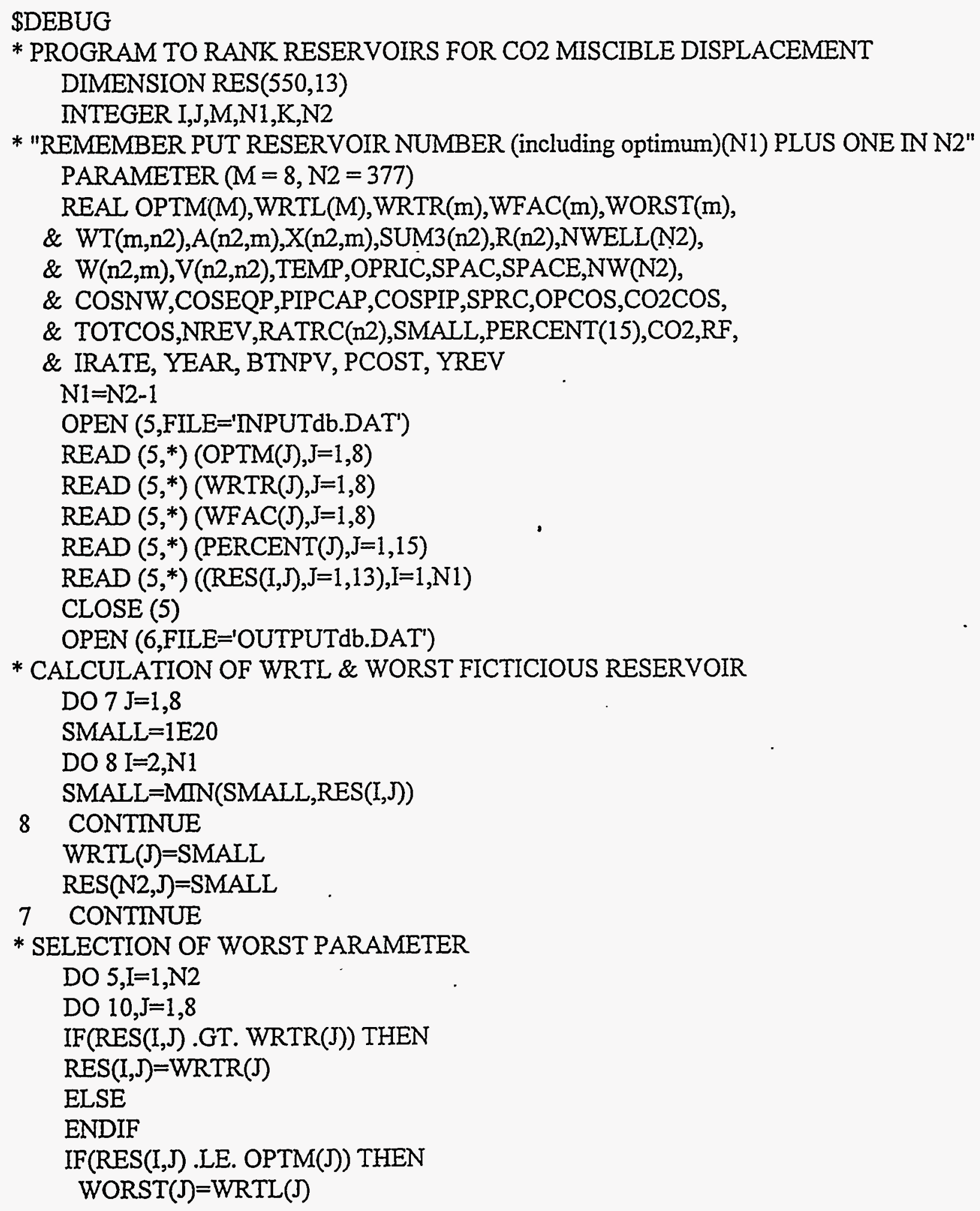


ELSE

WORST(J)=WRTR(J)

ENDIF

* CALCULATION OF NORMALIZED PARAMETER

TEMP=ABS(WORST(J)-OPTM(J))

$X(I, J)=(A B S(R E S(I, J)-O P T M(J)) / A B S(W O R S T(J)-O P T M(J)))$

* CALCULATION OF EXPONENTIAL FUNCTION

$A(I, J)=100 * \operatorname{EXP}(-4.6 *(X(I, J) * 2))$

* CALCULATION OF THE WEIGTHED MATRIX

$W(I, J)=A(I, J) * W F A C(J)$

10 CONTINUE

5 CONTINUE

* CALCULATION OF THE TRANSPOSED WEIGTHED MATRIX

DO15, I $=1, N 2$

$\mathrm{DO} 20, \mathrm{~J}=1,8$

$W T(J, I)=W(1, J)$

20 CONTINUE

15 CONTINUE

* CALCULATION OF THE PRODUCT MATRIX

$\mathrm{DO} 25, \mathrm{I}=1, \mathrm{~N} 2$

$\mathrm{DO} 30, \mathrm{~K}=1, \mathrm{~N} 2$

SUM1 $=0$

$\mathrm{DO} 40, \mathrm{~J}=1,8$

SUM1 $=S U M 1+W(I, J) * W T(J, K)$

40 CONTINUE

$\mathrm{V}(\mathrm{I}, \mathrm{K})=$ SUM 1

30 CONTINUE

25 CONTINUE

* CALCULATION OF OPTIMUM CHARACTERISTIC PARAMETER

$I=1$

SUM2 $=0$

$\mathrm{DO} 80, \mathrm{~J}=1, \mathrm{~N} 2$

$S U M 2=S U M 2+V(I, J)$

80 CONTINUE

RO=SUM2

* calculation of the characteristic parameters

DO90, $I=1, \mathrm{~N} 2$

$\operatorname{SUM} 3(\mathrm{I})=0$

$\mathrm{DO} 100, \mathrm{~J}=1, \mathrm{~N} 2$

$\operatorname{SUM} 3(\mathrm{I})=\mathrm{SUM} 3(\mathrm{I})+\mathrm{V}(\mathrm{I}, \mathrm{J})$

100 CONTINUE

$R(I)=(100 * S U M 3(I)) / R O$

90 CONTINUE

* END OF TECHNICAL RANKING - BEGINNING ECONOMIC RANKING

PRINT *,'TECHNICAL SCREENING READY'

PRINT *,'CONTINUE WITH ECONOMICAL SCREENING? YES=1, NO=0' 
* 4.4 CO2 PURCHASE COSTS $\mathrm{CO} 2 \mathrm{COS}=\mathrm{YREC} * 6 * \mathrm{CO} 2$

* 4.5 YEARLY GROSS REVENUE YREV $=($ YREC $*$ OPRIC $) /\left((1+\text { IRATE })^{* *}\right.$ YEAR $)$

* 4.6 NPV OF TIME DEPENDENT COSTS SUM4 $=(\mathrm{CO} 2 \mathrm{COS}+\mathrm{SPRC}+\mathrm{OPCOS}) /\left((1+\mathrm{IRATE})^{* *} \mathrm{YEAR}\right)$

* 4.7 BEFORE TAXES NPV OF NET INCOME

SUM5 $=$ YREV+SUM5

PCOST $=$ PCOST + SUM4

125 CONTINUE

BTNPV=SUM5-PCOST

* 5 TOTAL COSTS

TOTCOS $=$ COSNW + COSEQP + COSPIP + PCOST

* 6 NET REVENUE NREV=BTNPV-COSNW-COSEQP-COSPIP

* 7 BENEFIT/COST RATIO

RATRC $(\mathrm{I})=\mathrm{NREV} / \mathrm{TOTCOS}$

110 CONTINUE

PRINT 1000,(R(I),RATRC(I),NWELL(I),I=1,N2)

WRITE $(6,1000)(\mathrm{R}(\mathrm{I}), \mathrm{RATRC}(\mathrm{I}), \mathrm{NWELL}(\mathrm{I}), \mathrm{I}=1, \mathrm{~N} 2)$

PRINT *,'CHANGE ECONOMICAL PARAMETERS? YES $=1, \mathrm{NO}=0^{\circ}$

READ *,EC

IF (EC.EQ.1) THEN

GO TO 105

ELSE

CONTINUE

ENDIF

1000 FORMAT (1X,F6.2,2X,F6.3,2X,F4.0)

1010 FORMAT (1X,F6.2)

120 END 